\title{
LODGING REIT PERFORMANCE AND COMPARISON WITH OTHER EQUITY REIT RETURNS
}

\author{
By \\ LEONARD ANTHONY JACKSON \\ Doctor of Philosophy in Human Environmental Sciences \\ Oklahoma State University \\ Stillwater, Oklahoma \\ 2007
}
Submitted to the Faculty of the
Graduate College of the
Oklahoma State University
in partial fulfillment of
the requirements for
the Degree of
DOCTOR OF PHILOSOPHY

May, 2007 


\section{LODGING REIT PERFORMANCE AND COMPARISON WITH OTHER EQUITY REIT RETURNS}

Dissertation Approved:

Dr. Radesh Palakurthi

Dissertation Adviser

Dr. Woo Gon "Woody" Kim

Dr. Jerrold Leong

Dr. Gregory Dunn

Dr. Shiretta Ownbey

Dr. A. Gordon Emslie

Dean of the Graduate College 


\section{ACKNOWLEDGEMENTS}

As individuals, we are often molded and shaped by special people who touch our lives and instill value, morality, drive and determination into the fabric of our being. Such individuals often teach us how to be resilient and learn how to find ways to overcome adversity and life's challenges. In this regard, I would like to thank my mother, Millicent for the fortitude, drive, determination and values she instilled in me. These are the qualities that have enabled me to overcome life's challenges and accomplish this goal. I would also like to thank my daughter Kendra for being the bright ray of light that kept me focused on achieving this goal. Special thanks to Annette for her encouragement, and tremendous support.

I would also like to thank my advisor, Dr. Radesh Palakurthi for his unwavering support, guidance, assistance, and words of encouragement and most importantly for being an excellent mentor. I would also like to thank the members of my dissertation committee, Dr. Gregory Dunn, Dr. Woo Gon “Woody” Kim, Dr, Jerrold Leong and Dr. Shiretta Ownbey for their kind assistance. I would also like to extend my gratitude to the National Association of Real Estate Investment Trusts (NAREIT) for providing data that were not publicly available. 


\section{TABLE OF CONTENTS}

Chapter $\quad$ Page

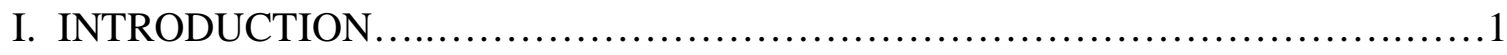

Structure and Paper Organization............................................ 10

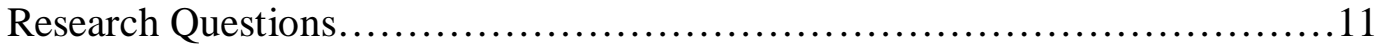

Statement of the Problem..................................................11

Definition of Terms and Abbreviations.....................................12

Assumptions............................................................... 14

Research Scope......................................................... 14

Importance of the Study ......................................................

II. REVIEW OF LITERATURE................................................ 18

Real Estate Investment trusts: History and Evolution.........................18

Real estate Investment trusts: The early years..........................18

The Growing Years:1970s.........................................23

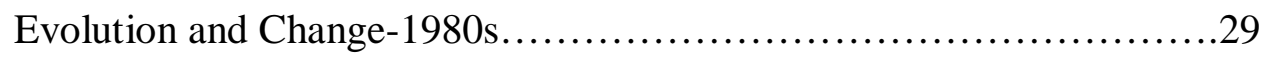

Maturity: The 1990s and Beyond.......................................36

History and Evolution Summary.....................................39

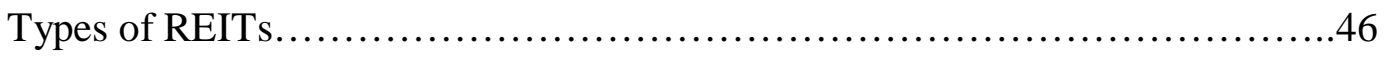


Public REITs.........................................................46

Finite Life REITs and Non-Finite life REITs........................48

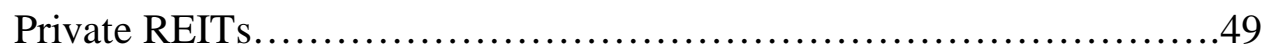

Unlisted REITs.................................................... 49

The Legal Structure of REITs ...........................................50

Legal Requirements..............................................50

Asset Requirements................................................ 51

Income Requirement............................................. 51

Distribution Requirement.........................................52

Stock and Ownership Requirement................................52

REIT Status Termination and Penalties..............................53

REIT Taxation and Dividends...........................................53

Management of Real Estate Investment Trusts..............................54

The Appeal of REITs as Investment Vehicles................................56

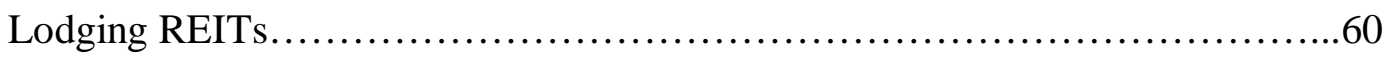

Performance of Real Estate Investment Trusts...............................65

REIT Performance as Investment Vehicles.............................65

Lodging REIT Performance.........................................69

Measuring and Benchmarking Investment Performance........................71

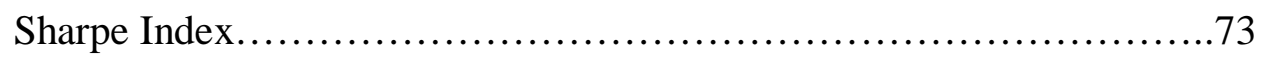

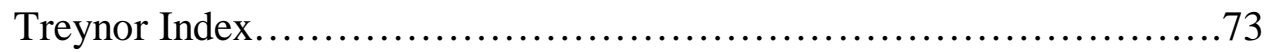

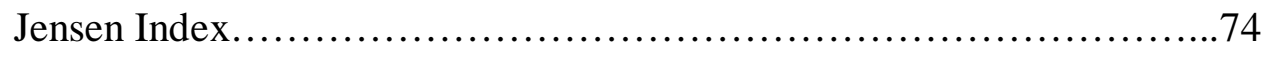


The Future of REITs...............................................76

III. METHODOLOGY.............................................. 79

Problem Statement............................................... 79

Research Design Overview......................................80

Research Questions........................................... 82

Research Question One..................................82

Research Question Two.................................83

Research Question Three.................................83

Data Collection and Data Source....................................84

Data Analysis................................................. 87

Validity And Reliability.........................................89

Summary................................................91

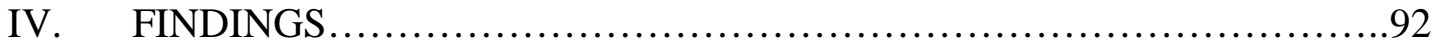

Analysis and Results...............................................92

Research Question one........................................99

Research Question two.......................................... 102

Research Question three.......................................105

V. CONCLUSION................................................ 107

Study Limitations and Suggestions for Further Research.............110

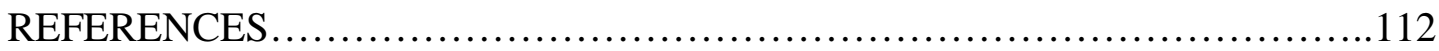

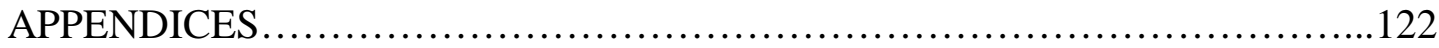

Appendix A: Monthly REIT Returns.................................. 123 


\section{LIST OF TABLES}

Table I: Historical REIT Industry Market Capitalization: 1971-2005...................2

Table II: REITs by Property Type and Percent of Market Capitalization..................4

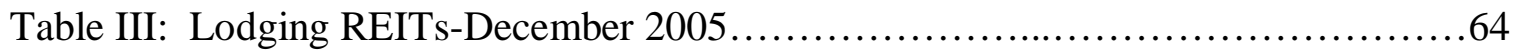

Table IV: Lodging REITs and Their Last Reported Market Capitalization...............86

Table V: Descriptive Statistics on Monthly Rate Jan. 1993-Dec 2005................93

Table VI: Performance of REIT Sector Relative to S\&P 500 Using Jensen Index.......94

Table VII: Performance of REIT Sector Relative to the CRSP Equally Weighted ......99

Table VIII: Performance of REIT Sector Relative to CRSP Value Weighted Index....100

Table IX: Performance of REIT Sector Relative to the NASDAQ ..................101

Table X: Test of Equality of Jensen Alphas for REIT Sector Using ANOVA..........103

Table XI: Calculation of Test Statistics in Jensen Alpha Using Tukey Method..........104

Table XII: Calculation of Difference in Period Parameters for Lodging REIT Sector..106 


\section{LIST OF FIGURES}

Figure $\quad$ Page

$1 \quad$ Scatter Plot of S\&P 500 Index Less Risk Free Rate...........................97

2 Frequency Histogram of S\&P 500 Index Less Risk Free Rate.................98 


\section{CHAPTER I}

\section{INTRODUCTION}

Over the past four decades, real estate investment trusts or REITs as they are commonly called have become a significant asset class. In fact, REITs have become the third largest asset class available to investors, behind bonds and stocks (Imperiale, 2002). The sustained growth of the public REIT market has been nothing short of phenomenal. For example, the past four decades have seen the industry expand from 34 publicly traded REITs with a market capitalization of $\$ 1.4$ billion in 1971 , to 197 , with a market capitalization in excess of $\$ 330$ billion at the end of 2005 (National Association of Real Estate Investment Trusts, Inc., 2006). During this period of exponential growth, the REIT investment vehicle of choice has been equity REITs which increased both in terms of number- from 12 in 1971 to 152 at the end 2005, and capitalization, from $\$ 332$ million in 1971 to $\$ 331$ billion at the end of 2005 . Table 1 presents a summary of the REIT industry market capitalization between 1972 and 2005.

Real estate investment trusts are companies that are publicly traded on the major US stock exchanges, namely the New York Stock Exchange, American or NASDAQ. From the perspective of investors, REIT stocks represent a form of securitized real estate with claims on real property and/or mortgages (Chan, Erickson, \& Wang, 2003). 
TABLE I

HISTORICAL REIT INDUSTRY MARKET CAPITALIZATION: 1971-2005

\begin{tabular}{|c|c|c|c|c|c|c|c|c|c|}
\hline & \multicolumn{3}{|c|}{ Composite } & \multicolumn{2}{|c|}{ Equity } & \multicolumn{2}{|c|}{ Mortgage } & \multicolumn{2}{|c|}{ Hybrid } \\
\hline End of & \# of & Market & Average & \# of & Market & $\#$ of & Market & \# of & Market \\
\hline Year & REITs & Capitalization & Capitalization & REITs & & & & & Capitalization \\
\hline 1971 & 34 & $1,494.30$ & 43.95 & 12 & 332 & 12 & 570.8 & 10 & 591.6 \\
\hline 1972 & 46 & $1,880.90$ & 40.89 & 17 & 377.3 & 18 & 774.7 & 11 & 728.9 \\
\hline 1973 & 53 & $1,393.50$ & 26.29 & 20 & 336 & 22 & 517.3 & 11 & 540.2 \\
\hline 1974 & 53 & 712.4 & 13.44 & 19 & 241.9 & 22 & 238.8 & 12 & 231.7 \\
\hline 1975 & 46 & 899.7 & 19.56 & 12 & 275.7 & 22 & 312 & 12 & 312 \\
\hline 1976 & 62 & $1,308.00$ & 21.10 & 27 & 409.6 & 22 & 415.6 & 13 & 482.8 \\
\hline 1977 & 69 & $1,528.10$ & 22.15 & 32 & 538.1 & 19 & 398.3 & 18 & 591.6 \\
\hline 1978 & 71 & $1,412.40$ & 19.89 & 33 & 575.7 & 19 & 340.3 & 19 & 496.4 \\
\hline 1979 & 71 & $1,754.00$ & 24.70 & 32 & 743.6 & 19 & 377.1 & 20 & 633.3 \\
\hline 1980 & 75 & $2,298.60$ & 30.65 & 35 & 942.2 & 21 & 509.5 & 19 & 846.8 \\
\hline 1981 & 76 & $2,438.90$ & 32.09 & 36 & 977.5 & 21 & 541.3 & 19 & 920.1 \\
\hline 1982 & 66 & $3,298.60$ & 49.98 & 30 & $1,071.40$ & 20 & $1,133.40$ & 16 & $1,093.80$ \\
\hline 1983 & 59 & $4,257.20$ & 72.16 & 26 & $1,468.60$ & 19 & $1,460.00$ & 14 & $1,328.70$ \\
\hline 1984 & 59 & $5,085.30$ & 86.19 & 25 & $1,794.50$ & 20 & $1,801.30$ & 14 & $1,489.40$ \\
\hline 1985 & 82 & $7,674.00$ & 93.59 & 37 & $3,270.30$ & 32 & $3,162.40$ & 13 & $1,241.20$ \\
\hline 1986 & 96 & $9,923.60$ & 103.37 & 45 & $4,336.10$ & 35 & $3,625.80$ & 16 & $1,961.70$ \\
\hline 1987 & 110 & $9,702.40$ & 88.20 & 53 & $4,758.50$ & 38 & $3,161.40$ & 19 & $1,782.40$ \\
\hline 1988 & 117 & $11,435.20$ & 97.74 & 56 & $6,141.70$ & 40 & $3,620.80$ & 21 & $1,672.60$ \\
\hline 1989 & 120 & $11,662.20$ & 97.19 & 56 & $6,769.60$ & 43 & $3,536.30$ & 21 & $1,356.30$ \\
\hline 1990 & 119 & $8,737.10$ & 73.42 & 58 & $5,551.60$ & 43 & $2,549.20$ & 18 & 636.3 \\
\hline 1991 & 138 & $12,968.20$ & 93.97 & 86 & $8,785.50$ & 28 & $2,586.30$ & 24 & $1,596.40$ \\
\hline 1992 & 142 & $15,912.00$ & 112.06 & 89 & $11,171.10$ & 30 & $2,772.80$ & 23 & $1,968.10$ \\
\hline 1993 & 189 & $32,158.70$ & 170.15 & 135 & $26,081.90$ & 32 & $3,398.50$ & 22 & $2,678.20$ \\
\hline 1994 & 226 & $44,306.00$ & 196.04 & 175 & $38,812.00$ & 29 & $2,502.70$ & 22 & $2,991.30$ \\
\hline 1995 & 219 & $57,541.30$ & 262.75 & 178 & $49,913.00$ & 24 & $3,395.40$ & 17 & $4,232.90$ \\
\hline 1996 & 199 & $88,776.30$ & 446.11 & 166 & $78,302.00$ & 20 & $4,778.60$ & 13 & $5,695.80$ \\
\hline 1997 & 211 & $140,533.80$ & 666.04 & 176 & $127,825.30$ & 26 & $7,370.30$ & 9 & $5,338.20$ \\
\hline 1998 & 210 & $138,301.40$ & 658.58 & 173 & $126,904.50$ & 28 & $6,480.70$ & 9 & $4,916.20$ \\
\hline 1999 & 203 & $124,261.90$ & 612.13 & 167 & $118,232.70$ & 26 & $4,441.70$ & 10 & $1,587.50$ \\
\hline 2000 & 189 & $138,715.40$ & 733.94 & 158 & $134,431.00$ & 22 & $1,632.00$ & 9 & $2,652.40$ \\
\hline 2001 & 182 & $154,898.60$ & 851.09 & 151 & $147,092.10$ & 22 & $3,990.50$ & 9 & $3,816.00$ \\
\hline 2002 & 176 & $161,937.30$ & 920.10 & 149 & $151,271.50$ & 20 & $7,146.40$ & 7 & $3,519.40$ \\
\hline 2003 & 171 & $224,211.90$ & 1311.18 & 144 & $204,800.40$ & 20 & $14,186.51$ & 7 & $5,225.00$ \\
\hline 2004 & 193 & $307,894.73$ & 1595.31 & 153 & $275,291.04$ & 33 & $25,964.32$ & 7 & $6,639.37$ \\
\hline 2005 & 197 & $330,691.31$ & 1678.64 & 152 & $301,490.98$ & 37 & $23,393.73$ & 8 & $5,806.61$ \\
\hline
\end{tabular}

Notes: Capitalization and Average Capitalizations are in millions of dollars; data source, NAREIT (2006) 
Essentially, today's REITs are pools of properties and /or mortgages that are traded on one of the stock exchange markets. To maintain their status as real estate investment trusts, these corporations are required by law to meet specific criteria established by the US tax code. One such criterion stipulates that, in return for favorable tax treatment, REITs must distribute ninety percent of their taxable income to shareholders. While this requirement might be attractive to some investors, especially those who require immediate return on their investments, this stipulation has the potential of hindering the long term growth of the REIT since this requirement effectively limits the ability of the company to use retained earnings for future property acquisition and development.

From an ownership and management perspective, REITs are companies that are designed to own and manage income producing real estate such as hotels, apartment complexes, shopping malls, golf courses, office buildings, self storage centers, multifamily residential, manufactured housing, industrial properties and commercial net lease. Essentially, purchasers of real estate investment trusts shares acquire assets that are either real property or mortgages. Table 2 presents a summary of current REITs by property and sub-sector types as well as their respective market capitalization.

REITs may also be described as specialized forms of investment companies that share characteristics similar to those of mutual funds. Like mutual funds, several investors can pool their assets to own participation in a number of real estate investments. REITs therefore operate like "mutual funds for real estate". This feature is especially important for small investors since the exorbitant cost of real estate often prevents this 


\section{TABLE II}

REITS BY PROPERTY TYPE AND PERCENT OF MARKET CAPITALIZATION

\begin{tabular}{|l|l|c|c|}
\hline Investment Sector & Type of REIT & Number of Companies & $\begin{array}{c}\text { Equity Market } \\
\text { Capitalization (\$ } \\
\text { millions) }\end{array}$ \\
\hline EQUITY & Retail & $\mathbf{3 3}$ & $\mathbf{8 5 , 6 4 6 . 7}$ \\
\hline & Shopping Centers & 18 & $38,114.1$ \\
\hline & Regional Malls & 9 & $41,620.0$ \\
\hline & Free Standing & 6 & $5,912.6$ \\
\hline & Industrial/Office & $\mathbf{3 4}$ & $\mathbf{8 8 , 2 7 1 . 1}$ \\
\hline & Office & 23 & $58,909.0$ \\
\hline & Industrial & 6 & $19,442.1$ \\
\hline & Mixed & 5 & $9,920.0$ \\
\hline & Residential & & $\mathbf{5 5 , 4 9 5 . 0}$ \\
\hline & Apartments & 19 & $53,557.8$ \\
\hline & Manufactured Homes & 4 & $1,937.2$ \\
\hline & Diversified & $\mathbf{1 3}$ & $\mathbf{2 2 , 8 5 7 . 2}$ \\
\hline & Lodging/Resorts & $\mathbf{1 7}$ & $\mathbf{2 3 , 6 3 7 . 5}$ \\
\hline & Self Storage & $\mathbf{5}$ & $\mathbf{1 4 , 4 8 7 . 3}$ \\
\hline & Health Care & $\mathbf{1 2}$ & $\mathbf{1 5 , 2 0 7 . 2}$ \\
\hline & Specialty & $\mathbf{9}$ & $\mathbf{1 7 , 3 9 1 . 6}$ \\
\hline MORTGAGE & Mortgage REITs & $\mathbf{3 7}$ & $\mathbf{2 5 , 7 4 3 . 8}$ \\
\hline & Home Financing & 26 & $18,413.7$ \\
\hline HYBRID & Commercial Financing & 11 & $7,330.0$ \\
\hline REIT Industry Total & Hybrid REITs & $\mathbf{8}$ & $\mathbf{6 , 3 2 0 . 5}$ \\
\hline
\end{tabular}

Source: National Association of Real Estate Investment Trusts, www.nareit.com (May, 2006)

group from actively participating in the real estate market since most ordinary investors simply do not have the resources to procure these properties. REITs however are dissimilar to stocks or bonds in that unlike stocks or bonds which are bought, kept or traded on a constant basis, REITs are operating companies which offer their stocks for sale. It should be noted however that although REITS are essentially different from common stocks, their returns are usually determined by the performance of the underlying assets owned by the trusts. As noted previously, the responsibilities of REITs 
often extend beyond real estate ownership and often include actively managing the real estate. This active and participatory management includes securing tenants, collecting rent, paying bills and handling the overall day to day functions associated with running, owning and operating the real estate. In this regard, REITs differ from mutual funds in that mutual funds do not manage the companies they invest in.

These REIT characteristics therefore make it possible of investors to participate in a diverse portfolio of investments which they could never achieve otherwise. Given the tremendous potential and benefits that REITs offer to both investors as well as owners, it is therefore no surprise that over the past decade, a significant trend within the real estate sector has been the transformation of private property ownership to REITs that are publicly traded (Brady \& Conlin, 2004).

The performance of real estate investment trusts can be examined from several perspectives. First, since the majority of real estate investment trusts are publicly traded companies (Brueggerman \& Fisher, 2005), their performance as business entities has been judged based on the performance of their stocks on the public stock exchanges. In this regard, research pertaining to the performance of REITs has compared such performance against relevant market (market portfolios) benchmarks such as the S\&P 500, NYSE, and the NASDAQ composite. Such research has yielded mixed results. In fact, empirical results relating to REIT performance over the past four decades have been at best mixed. In addition, existing studies on the performance of REITs lack consensus, especially as it pertains to the performance of REITs compared to relevant benchmarks. In general, results of existing research on REIT performance have arrived at one 
of four conclusions. Such research findings have indicated that when compared to relevant industry benchmarks on a risk adjusted basis, REITs have either exceeded the market (Kuble, Walther, \& Wurtzebach, 1986), underperformed the market,(Wang, Erickson, Gau, \& Chan, 1997;Goebel \& Kim, 1989), performed slightly better or about the same (Glascock \& Hughes, 1995;Smith, 1980; Smith \& Schulman, 1976), or performed slightly worse than, or no better than the market portfolio (Sanders, 1998;Han \& Liang, 1995; Howe \& Shilling, 1990). On a nominal return basis, when compared to relevant industry benchmarks, the trend remains the same. REITs have either underperformed the market (Chen \& Peiser, 1999; Glascock \& Hughes, 1995), displayed performance that was similar to the market (Wang et al., 1997), or performed about as well as, or no better than the market (Smith \& Schulman, 1976).

An analysis of the findings from previous studies on the long-term performance of REITs also suggests that performance appears to be a function of the time period during which these studies were conducted. Research conducted during the early years of REIT development and growth (during the 1960s and throughout the 1980s) appears to be in general consensus that the performance of REITs as indicated by their returns appear to be similar to the general stock market. For example, Smith \& Schulman, (1976) compared the performance of equity REITs against common stocks during the period January 1963 to December 1974, and found that over the sample period, equity REITs performed the same, or similar to, but not better than common stocks, on both a risk adjusted basis and nominal basis. The exception was 1974, when the underperformance of equity REITs was attributed to overall poor market conditions. Similar findings were 
reported by Smith, (1980) who compared the performance of equity REITs against common stocks between 1965 and 1977 and also found that equity REITs performed the same as common stocks on a risk adjusted basis.

Conversely, recent studies conducted to ascertain the performance of REITs compared to other stocks tend to contradict the findings of the earlier studies. Later studies tend to suggest that compared to other stocks, REIT stock performance appears to be less impressive. Instead, such studies indicate that REIT stocks either underperform the market or at best, performed similar to the market on a risk adjusted basis. Such findings for example were reported by Sanders, (1998) who examined the historical performance of REIT returns on a risk adjusted basis as measured by the NAREIT index, against market benchmarks such as the S\&P 500 index and the Wilshire index. During the of 1978 to 1996, in terms of their risk-adjusted excess returns, equity REITs were found to perform no better than the stock market indices, Sanders (1998).

Evidence from the literature also suggests that REITs perform differently over various time periods, when compared to the stock market. For example, early studies on long run performance of REITs, conducted between the 1960's through the 1980's suggest that REIT returns are similar to or about the same as those of the stock market (Smith \& Schulman, 1976; Smith, 1980). More recent studies however do not support such findings, and instead portray REIT performance as less impressive than previously indicated. In fact, more recent studies have either reported that REIT stocks either underperform the market (on a risk-adjusted basis) or performed no better than the market (Goebel \& Kim, 1989; Howe \& Shilling, 1990; Chan, Hendershott, \& Sanders, 1990; 
Martin \& Cook, 1991; Glascock \& Hughes, 1995; Wang, Erickson, Gau, \& Chan, 1995; Wang et al., 1997; Chen \& Peiser, 1999).

Studies conducted to evaluate the performance of REITs during sub-periods have also yield mixed results when compared to the overall market. For example, Sanders (1998), in his study of the historical performance of REITs found that during the period January 1978 to December 1986, equity REIT stocks outperformed key stock market indices. However, the study also found that during the January 1987 to October 1990 period, risk adjusted equity REIT returns were found to perform below the stock market. The study also found that during a more recent period, from November 1990 through June 1996, REITs outperformed the S\&P 500 index. Interestingly however, REITs did not perform better than the Wiltshire index. One plausible explanation for this finding is the fact that unlike the S\&P 500, the Wiltshire index contains the stocks of small companies, and generally, small stocks tend to outperform large stocks (Chan et al., 2003). Similar performance results were reported by Han \& Liang (1995), who examined the issues of whether REITs performed differently from common stocks, whether REIT performance varies significantly over time, and whether REIT performance is sensitive to the time period and choice of performance benchmarks. Han \& Liang (1995) found that REITs performed no better or somewhat more poorly than a broad stock market index over the period 1970-1993. However, REIT performance was found to be better in some sub-periods and worse in others. Large REIT performance was also found to be more stable than small REITs. One plausible explanation for this finding is the fact that larger REIT portfolios tend to be more diversified than those of 
smaller REITs, especially in terms of number of properties owned.

Still, others argue that although quantitative analysis plays a significant role in the evaluation of REIT performance, the qualitative aspects of real estate such as property development should not be overlooked as these aspects have a direct effect on a REIT's performance. Brounen, Eichholtz, \& Kanters (2000), argue that investors often attest that property development activities such as renovations will also increase the performance of REITs. This notion however could be fallacious since Brounen, Eicholtz, \& Kanters, (2000) found that although developing REITs yield higher returns than REITs that do not develop, when risk is taken into account, there is no synergy or relationship between property development and REIT investment returns. In terms of lodging REITs, Gordon \& McCarthy, (1998) in a study on lodging REITs argued that the actual performance of lodging REITs on the stock market in terms of actual returns may not necessarily be connected to, or a reflection of the performance of the physical assets themselves. Instead, they argued that there is a disconnect between the performance of the real property and the performance of the investment as measured by returns. Consequently, they argued that REITs performance as measured by returns are more a function not of the performance of the real property, but instead is more reliant on the management expertise of investment mangers.

Given the contentious and often conflicting findings regarding REIT performance, it is important that the performance of REITs is examined from several perspectives. This is especially important since the debate over REIT performance will remain and continue in the future. Although several studies have been conducted on the performance of 
REITs since their emergence in the 1960's as viable investment vehicles, little research has been conducted to ascertain the performance of one key and growing sub-sector of the equity REIT segment, hotel or lodging REITs.

As investment vehicles, it is crucial that the performance of lodging REITs is examined given the volatility and cyclical nature of the lodging industry. The importance of examining hotel real estate investments is highlighted by DeRoos, (1997), who pointed to the growing importance of hotel capital markets. This point was accentuated by Kim et al., (2002) who suggested that research that focuses on the performance of hotel real estate investment trust will lead to a better understanding of the performance of lodging assets as investment vehicles, which will ultimately provide information that can be used by prudent investors.

Thus, the primary goal of this research is to ascertain the performance of lodging REITs and in the process shed some light on this segment's performance, compared to relevant market benchmarks and other equity REITs. This research will therefore fill a gap in the existing literature, and add to our knowledge of lodging REIT performance.

\section{STRUCTURE AND PAPER ORGANIZATION}

This research is developed through five chapters. Chapter one focuses on the research problem and its setting and will include the introduction, research questions, problem statements, definition of terms and abbreviations, assumptions, research scope and importance of the study. Chapter two presented a review of related literature while chapter three focused on the methodology utilized in this research. Chapter four 
comprised a detail explanation of the research findings while chapter five focused on interpretation of the results and offered recommendations for further study.

\section{RESEARCH QUESTIONS}

The purpose of this research is to examine the long term (period exceeding ten years) performance United States lodging REITs between the period January 1993 and December 2005. Performance is measured by how well lodging REITs performed during the period compared to other equity REITs and relevant benchmarks. The study attempted to address the following three questions: 1) Do lodging REITs over perform or under-perform relevant market benchmarks? 2) Do lodging REITs over-perform or under-perform other equity REITS? 3) Is the performance of lodging REITs persistent?

\section{STATEMENT OF THE PROBLEM}

Despite the fact that several studies have examined the long term performance of REITs as a whole, to date little research has been conducted in the area of examining the performance of a key segment of the equity real estate market, lodging or hotel REITs. It is essential that such studies are conducted since this segment of the REIT industry represents an ever growing and significant asset class. For example, at the end of 2005, there were 19 lodging REITs in the United States, with assets exceeding \$330 billion.

It is also especially important to study and understand the performance of lodging REITs since, unlike other types of REITs, at least $75 \%$ of their assets are invested in either the real property or in the property's mortgage (Kim et al., 2002). This study will therefore add to our understanding of the behavior of lodging REITs as investment 
vehicles. This study is also important since it will provide information that can assist investors in making investment as well as diversification strategy decisions.

This study is therefore designed to determine whether or not lodging REITs performed better than relevant benchmarks or if they performed worse than such benchmarks. The study also addressed the issue of whether lodging REITs performed better than other equity REITs of if they performed worse. Finally, lodging REITs performance persistence was examined in this study.

\section{DEFINITION OF TERMS AND ABBREVIATIONS}

For the purpose of this study, the following terms are defined as follows:

REIT: Acronym for real estate investment trust, which is a company that owns, and/or in most cases operates income producing real estate. To be classified as a real estate investment trust company, a business entity must distribute at least $90 \%$ of its taxable income to shareholders annually in the form of dividends.

Mortgage REITs: These are real estate investment trust companies that lend money directly to real estate owners and their operators, or indirectly through acquisition of loans or mortgage-backed securities.

Hybrid REITs: These are real estate investment trust companies that invest in properties and make loans to owners and operators.

Benchmarks: Relevant established market portfolios against which to measure performance.

Market Capitalization: Market capitalization is the number of publicly traded shares 
times the current market price of the stock.

Exchange-traded: This means that the shares are traded on the New York Stock

Exchange, the American Stock Exchange, or over the counter on the National

Association of Securities Dealers Automated Quotation (NASDAQ), system.

Risk: The probability of a loss or deviation from expected results. Risk is also the chance that an investment's actual return will be different than expected.

Systematic Risk: The risk inherent to the entire market or entire market segment.

Also known as "un-diversifiable risk" or "market risk", this type of risk is caused by market events and therefore results from forces outside the firm's control and is not unique to a given security, it cannot be controlled through diversification.

Unsystematic Risk: This is the risk that affects a single asset or a small group of assets. Since this type of risk is unique to individual companies or assets they are also termed unique or asset specific risks. This type of risk can be controlled through portfolio diversification.

Security Market Line: The general relationship that shows the risk-return trade-off for an individual security. Hence, it is the positively sloped straight line displaying the relationship between expected return and beta.

Beta: This is a relative measure of the non-diversifiable risk of an individual asset when it is added to a diversified portfolio. Hence, it is a measure of the systematic or market risk of a firm's common stock and therefore measures the sensitivity of an asset's return to the overall change in return on the market portfolio. Hence, Beta is a measure of the volatility, or systematic risk, of a security or a portfolio in comparison to the market as a 
whole.

Market Risk Premium: This is the slope of the security market line, the difference between the expected return on a market portfolio and the risk free rate. It is also defined as the difference between the expected return on the market portfolio and the risk-free rate.

Performance Persistence: Refers to the performance consistency of funds or investments from one period to another. For example, a REIT that performs well (or badly) in one period is considered to be persistent if it performs the same in subsequent periods.

\section{ASSUMPTIONS}

This study utilized data obtained from the Center for Research in Security Prices (CRSP) database. Specifically, it utilized the monthly stock returns for lodging REITs during the period January 1993 to December 2005. It is assumed that the data accurately reflects lodging REIT performance during the examination period.

\section{RESEARCH SCOPE}

For the purpose of this study, only US lodging REIT data available from the CRSP data base were examined. Further, only data available from the CRSP database during the period January 01, 1993 to December 31, 2005 are examined.

\section{IMPORTANCE OF THE STUDY}

The purpose of this research is to examine the performance of lodging real estate investment trusts during the period 1993-2005. This research will provide information 
that will add to our knowledge of how lodging REITs perform as investment vehicles. This knowledge will lead to a better understanding as well as help real estate investors understand the nature of their REIT investment. Further, knowledge of the performance of lodging REITs will also assist asset managers and hospitality executives in effectively managing their lodging real estate portfolios, with the ultimate goal of maximizing shareholders wealth.

Despite the fact that several studies have examined the long term performance of REITs as a whole, to date little research has been conducted in the area of examining the performance of a key segment of the equity real estate market, lodging REITs. It is also especially important to study and understand the performance of lodging REITs since unlike other types of REITs, at least $75 \%$ of lodging REIT assets are invested in either the real property or in the property's mortgage (Kim et al., 2002). This research will therefore add to our understanding of the behavior of lodging REITs as investment vehicles. Further, it is important to examine the performance of REIT stocks since unlike the price of real property, REIT prices changes on a continuous basis. The information that this research provides is important since it offers insights that will assist investors in making investment as well as diversification strategy decisions.

Further, given the fact that the hospitality industry is prone to, and is affected by events in the macro economic environment as well as single and unpredicted events, it is important that this study is undertaken so as to provide information especially for investors to ascertain whether or not they should invest in lodging REITs.

As a publicly traded asset class, the importance of real estate investment trust as 
viable investment vehicles is best highlighted by their market capitalization. Table 1 highlighted the rapid growth of REITs in terms of total market capitalization. As the table shows, at the end of 1971 , the total equity market capitalization of REITs was $\$ 1.4$ billion. However, by the end of 2005, the total market capitalization of all exchange traded REITs had surpassed $\$ 330$ billion. The number of initial public offerings (IPO's) is also an indication of the growth and importance of publicly traded companies. Between the years 1982 and 1991, there were a total of 116 IPOs of REIT stocks which raised $\$ 9.4$ billion in equity capital. During the same period, 133 secondary equity offerings raised $\$ 5.2$ billion in capital for publicly traded REITs, while secondary debt offerings raised a total of $\$ 9.5$ billion. The year 1991 was significant in terms of REIT growth as it marked a surge in the real estate investment market. Between the years 1993-1994 a total of 95 initial public offerings of REITs were made. However, since 1994, it appears as though the REIT market has cooled or matured as there were only 109 initial public offerings between the years 1995 to 2005 (IPO Vital Signs, 2005; National Association of Real Estate Investment Trusts [NAREIT], 2006).

However, in terms of importance, perhaps the most significant indication and validation that REITs have arrived as viable mainstream asset class/investment vehicles is the fact that as of June, 2006, the Standard \& Poor 500 which includes the leading companies in corporate America, included eleven REITs (National Association of Real Estate Investment Trust [NAREIT], 2006).

Given the exponential growth of REITs as indicated by the number and growth of IPOs, one could speculate that in the long term, the number of real estate investment 
trusts will continue to grow. Accordingly, as the number of REITs and their prominence as viable investment vehicles continue to grow, it becomes acutely important for both investors and managers of real estate investment trusts to develop a better understanding of how they perform as investment vehicles. This is especially important because of the fact that although REIT stocks are traded like other stocks on the regular, public markets, they have been found to have unique characteristics which cause them to act differently from other general stocks on variables such as dividend policies, return prediction, capital structure, as well as initial and seasoned public offerings (Chan et al., 2005). It therefore is paramount that studies such as this one is undertaken to shed light on the performance of lodging REITs.

Further, given the rapid expansion and growth in the number of REITs combined with the growth in institutional interests in them as viable investment vehicle combined with the fact that research has shown that they perform differently from other stocks, it is important that studies are conducted to document their performance as investment vehicles. 


\section{CHAPTER II}

\section{REVIEW OF LITERATURE}

This chapter presents a review of literature relating to real estate investment trusts and their performance. To provide an in-dept understanding of the REIT industry, this chapter will first outline the history and evolution of real estate investment trusts as viable investment vehicles. The chapter then focuses on the types of REITs and their legal structure as well as REIT termination status and penalties. The appeal of REITs as viable investment vehicles is also addressed. Following this, the concept of lodging REITs, the primary focus of this research is discussed. Literature related to the performance of REITs is also discussed. Finally, the chapter focuses on measuring and benchmarking performance and lodging REIT performance. These topics are essential as they establish the background and foundation for this research.

\section{REAL ESTATE INVESTMENT TRUSTS: HISTORY AND EVOLUTION}

\section{Real Estate Investment Trusts: The early Years}

The evolution and history of the REIT industry in the United States can be best described by two words, resilience and persistence. In its relatively short life, the REIT 
industry has enjoyed successes as well as failures, punctuated by notable booms and busts. Accordingly, as investment vehicles, the performance of REITs has also fluctuated dramatically between periods of pronounced booms and distinct busts. These distinct periods are marked by the distinct declines brought on by bankruptcies in the 1970s, inflation induced decline in the 1980s, followed by rapid expansion in the latter part of the 1980's brought on through the direct action of government intervention, followed by decline in the early 1990s and eventual growth in the latter part of the 1990s which continued through the 2000s.

The concept of real estate investment trusts in the United States dates back to the early 1880s. Although most literature document the origin of REITs to the passage of the Real Estate Investment Trust Act of 1960, their actual genesis can be traced back to the early 1900s when the Massachusetts Trust Company was formed by a group of New England entrepreneurs who wanted to profit from the burgeoning real estate industry. At the time, under Massachusetts law, corporations could only own real estate if the real estate was a key component of the business (Chan et al., 2003). Accordingly, the only way for the Massachusetts Trust Company to take advantage of the real estate market while at the same time adhering to the law was to develop the Massachusetts Trust Company, a REIT like structure which legally allowed the corporation to invest in real estate, while at the same time enjoy benefits usually reserved for corporations such as the transferability of ownership shares, centralized management and limited liability (Chan et al., 2003).

Unlike today's REITs that are easily available to willing investors, these early 
trusts were not available to the general public as investment vehicles and were effectively established as business trusts. Instead, they were initially available only to the affluent segment of New England society (Maloney, 1998; Chan et al., 2003). However, over time they became available to the general investing public (Valachi, 1977).

This early trust allowed investors to pool their resources, which provided them with the ability to acquire larger and diverse holdings than would be available to individuals. The trust was also attractive as an investment vehicle since it was exempted from federal taxation which meant that individual investors could receive income derived from rent that were tax free at the individual level. However, this tax exemption was on the condition that the income derived from these trusts was distributed to beneficiaries. These trusts were treated like partnerships and subchapter S corporations and like other pass through entities. Hence, these trusts were taxed only at the shareholder level.

In time, the Massachusetts Trust Company grew to include the general public and expanded from the New England area to Chicago, Omaha and Denver. However, the Great Depression of the 1930s stagnated the growth of real estate investment and development, hence hampering further expansion of the Massachusetts Trust Company. The early growth of real estate investment trusts was further stunted when the United States Supreme Court ruled in 1935 that all passive investment vehicles that were centrally organized and managed like corporations should be taxed as corporations. This ruling included REITs and as a result, such trusts were no longer exempted from corporate taxation and their entity level taxation ceased to exist. Consequently, they became less attractive as investment devices. Further, during these early periods, real 
estate investment trusts were not organized to the point where they could effectively lobby or petition Congress and press for a repeal of the legislation. However, by the 1950's, advocates of the real estate investment trust started to lobby the United States Congress to pass legislation that would grant favorable tax treatment to real estate investment trust companies.

Over the next decade, the concept of real estate investment trusts remained dormant until 1960 when the United States Congress passed the Real Estate Investment Act which effectively ushered in the modern day REIT concept. This Act which became effective in 1961 was prompted by the fact that following World War II, there was a need for large amounts of real estate equity and mortgage funds, which in turn spurred renewed interest in real estate investment trusts. As a result, a campaign was launched to obtain special tax considerations for REITs that were comparable or similar to those received by mutual funds. As a consequence of this lobbying, the United States tax code was amended to allow real estate trusts to be treated like closed-end mutual funds, which meant that real estate companies could become companies whose assets could be a portfolio of common stocks. Hence, the REIT structure formed in 1961 represented a closed end structure. This meant that REITs could issue shares to the public, while the value of those shares would fluctuate between the net asset value and the value of the REITs. Thus, this structure developed in 1961 offered investors, especially small investors the opportunity to invest in real estate at reduced costs, as well as access to investment expertise. These early REITs were designed as passive investment vehicles, which meant that REITs could not actively participate in the management of their REIT 
owned properties. As a result, early REITs employed independent property management firms or leased their properties to third parties. This structure however has changed in recent years as many REITs have now become management companies as well.

Prior to the passage of the Real Estate Investment Act, small investors in entities could assemble a diversified liquid portfolio of stocks without having to buy mutual fund shares. However, the enormous capital requirements of real estate projects excluded most small investors from participating in the real estate sector. Hence, the passage of the Act not only made REITs the real estate equivalent of mutual funds, but also provided small investors with the opportunity to participate in large, professionally managed real estate projects, while at the same time maintain liquidity. Effectively, this Act allowed investors to share in the benefits offered by real estate investment, without being exposed to extreme risks or being subjected to the capital investments required of large scale commercial real estate development. Thus, the Act created a structure that enabled investors, especially small investors to participate in large scale commercial real estate investing and/or mortgage lending and in return receive a continuous stream of returns in the form of dividends (Block, 1998). Further, the Act outlined the legal structure within which REITs should operate by establishing certain rules which ensured that REITs remained similar to mutual-fund-like devices for the ownership of real estate.

Modern day REITs are a therefore a direct creation of the Internal Revenue Code (Brueggeman \& Fisher, 2005) and the United States Congress (Lee \& Lee, 2003), and were designed to be pass-through entities that distribute to its shareholders a substantial portion of its earnings in addition to capital gains generated from the sale or disposition 
of its assets. It is important to note that prior to the passage of Act in 1960, investors could only participate in the real estate market through the purchase of real estate and not from the stock market. However, once REITs were formally created, individuals, particularly small investors could for the first time participate in the real estate market through REITs, since they could now purchase stocks of real properties or real estate mortgages owned by these corporations.

In terms of the management of these early REITs most employed advisory boards or firms that received fees for their services which were usually calculated as a percentage of total assets for services rendered. This relationship however often created agency problems. This is because, many of these early REIT managers did not have any significant or large investments in the REIT stocks that were under their management, and as a result many of the management decisions were not necessarily always in the best interest of the REITs or shareholders (McMahan, 1994).

\section{The Growing Years-1970s}

It is important to note that during the early years (in the 1960s), the majority of REITs invested primarily in real property and not in mortgages. However, by the end of the 1960s and the start of the 1970s, several REITs started to focus on mortgage lending as compared to only direct property investments. As a result, the majority of REITs that were developed between 1968 and 1970 were mortgage REITs. Overall growth in the number of REITs during this period was also slow, due largely in part to a decline in the overall stock market. However, by the early 1970s, the number of REITs grew 
significantly. There are several reasons that account for this growth. First and foremost is the fact that by 1970 , REIT securities had started to gain acceptance on the capital markets as viable investment vehicles. In addition, between the years 1968-1973, credit conditions had changed significantly within the United States. This was further worsened by escalating interest rates, which soared to all time highs during the period. These conditions resulted in a situation where there was a shortage of funds, particularly for construction and development. Further, regulatory and statutory restrictions at the time prevented traditional lending institutions such as commercial banks, thrifts and insurance companies from directly engaging in the funding of construction and development activities. One such restriction that these institutions faced was the fact that they were prevented from raising funds by paying higher interest rates to attract deposits. As a result, many of these institutions resorted to establishing publicly funded REITs to fund these ventures. This led to the creation of Mortgage REITs which were required to have $75 \%$ of their holdings in financial assets such as mortgages (as compared to equity REITs which were required to invest $75 \%$ of their assets in real property), which took advantage of these opportunities to finance real estate business ventures. The simple reason, for this is the fact that unlike, the traditional lending agencies, mortgage REITs interest rates were not regulated, and as a result, they were able to pay higher interest rates to secure funding to finance such ventures. The result is that several lending institutions such as banks established their own mortgage REITs, to circumvent the regulatory restrictions. Further, these lending institutions, using their expertise, acted as third party advisors to the trusts they created. Hence, these direct activities effectively launched the growth of 
mortgage REITs (Chan et al., 2003).

Unfortunately for this new and burgeoning industry, the rapid growth of these lending institutions created intense competition amongst lenders, which resulted in the financing of questionable projects. As a consequence, the REIT industry suffered another setback especially in the mortgage REIT sector. This was due in part to the fact that the availability of mortgage REIT financing resulted in a situation where the market was effectively overbuild in a relatively short period of time in conjunction with poor investment decisions. As a result, by 1973, there was an excess in the supply of real estate in several United States markets. This was further exacerbated by escalating interest rates, propagated by inflation, as well as increases in the price of construction materials brought on by shortages in construction materials. This resulted in several borrowers defaulting on their loans. To make matters worse, the stringent REIT qualification requirements also meant that REITs could not immediately adjust structurally to changes in the marketplace. For example, the REIT condition that restricted the ability of REITs to sell their properties within a given time frame hampered their ability to diversify their asset portfolios to remove or eliminate properties that underperformed. Consequently, between 1973-1975, total REIT assets declined by $40 \%$ while the value of the total equity REIT common market declined by $68 \%$ during the same period (Chan et al., 2003).

Most of the losses suffered by REITs during the 1970s were in the mortgage sector. However, equity REITs performance experienced a different fate. In fact, this was the sector that performed the best. In 1972, investor returns on mortgage and hybrid 
REITs were $10 \%$ and $18 \%$ respectively. However, by 1974 , these returns had declined to $-50 \%$ and $-76 \%$. Conversely, during the same period, equity REIT returns were $11 \%$ at the end of 1972 and 57\% at the end of 1974 (Imperiale, 2002).

In response to the problems faced by REITs, the United States Congress passed the Tax Reform Act of 1976. This Act included several changes in the tax structure and requirements as well as provisions that pertained to REITs. However, these laws were clearly not designed to address the losses in REIT earnings. For example, the new law required that REITs increase the dividend payout of their earnings from 90\% to 95\%. Instead, the laws were designed to create a less rigid operating environment for REITs, especially under the adverse economic conditions of the 1970s. For example, the under the Tax Reform Act of 1976, the stipulation of the $75 \%$ and $90 \%$ gross income requirement was somewhat relaxed. If REITs inadvertently failed to meet these requirements (unlike previously), they would not automatically loose their REIT status or automatically be disqualified. In addition, capital gains and operating loss treatment were also modified to allow REITs to record eight years of losses to be carried forward thereby reducing the incentive for REITs to disqualify itself.

Under the new law also, REITs were also allowed to hold property for sale. However, such sale would incur a $100 \%$ excise tax on the income produced from the sale of such properties. However, this excise tax would not be administered if the REIT followed the established criteria of limiting the number of properties that were sold as well as maintain the minimum four year holding period. Further, if the REIT acted as an investor rather than as dealer, then this $100 \%$ tax would not be levied. 
Despite these changes, several REITs opted to exit the industry and instead chose to operate as corporations, which allowed them to more effectively and quickly adjust to changes in the operating environment (Chan et al., 2003). However, despite these setbacks, it has been argued that the Tax Reform Act of 1976 resulted in an improved REIT market with improved REIT performance and resulted in fewer risks. This was largely due to the fact that the market effectively corrected itself, and those REITs that were inefficient exited the market (Sanger, Sirmans, \& Turnbull, 1990). Further, surviving REITs took advantage of the relatively lower real estate prices that resulted from the over built market and expanded their asset base as well as their portfolios. This also resulted in several mortgage REITs, (which were the norm and quite popular during the early 1970s) converting to equity REITs, since many of their mortgage holders had to foreclose on their properties, which also effectively made these mortgage REITs holders the owners of these real estate assets. Hence, the 1970s was a period highlighted by institutional and investor adjustments as they became acquainted with REITs as investment vehicles and as they learned about the performance and behavior of these investment vehicles, and accordingly modified their strategies to effectively deal with them.

The 1970s also saw the development of various creative schemes to circumvent the restrictive regulations required to maintain REIT status. One of the most restrictive technical requirement asserted that the management of REITs should be passive, not active. This meant that a REIT could not actively participate in the day to day operation or management of properties they owned. Instead, they had to lease the properties to 
third parties, who in turn would pay the REIT rent for use of the property. This process resulted in the REIT forfeiting some of its potential profits to the service provider or lessee. The potential cash lost to the lessee was termed "leakage". Many REITs found this requirement excessively restrictive and sought creative ways to reduce or eliminate "leakage" while at the same time exercise greater control over their assets and ultimately, their profit objectives.

One such creative REIT structure was the "Paired-Share" structure. Paired share REITs were developed in the 1970s and continued through the 1980s. This structure was created as a direct response to concerns about lack of control over assets and was therefore developed as a direct solution to the leakage problem. Under this structure, the REIT that owns the real property created a subsidiary operating company to operate or manage the real property. The operating company would be taxed as a separate entity, however, it would pay most of its income to the REIT as rent. Under this arrangement, the shares of both the REIT and the operating company (C-Corporation) are combined (as if stapled) and trade together as a unit, in equal allotments. Paired-share REITs offer these advantages: 1) they complied with the REIT rules and receive the associated tax benefits, 2) they could invest in operationally intensive businesses, such as hotels, 3) they could maintain control over the assets, and 4) they provided investors with an opportunity to receive the full economic benefits of the investments. Any advantage lost by the REIT due to revenue-based leases mandated by REIT rules was retained by REIT shareholders, because they also owned shares in the C-Corporation operating side of the paired share structure. However, the number of paired share REITs was restricted (Beals \& Arabia, 
2003).

The United States Congress eliminated the opportunity to form paired share REITs in 1984. However, the same body grandfathered the existing paired-share REITs. Today, only five paired share REITs exist, three of which currently own and manage hotels (National Association of Real Estate Investment Trusts, Inc [NAREIT], 2006).

The 1970s also saw the emergence of another creative REIT structure, the paperclip structure. A paper clip REIT closely resembles a paired share REIT in that it combines a C-Corporation (operator) and a REIT (owner). In a paired share REIT, both companies trade as a single unit, whereas in a paper clip REIT, the two organizations are separate public companies but enjoy a symbiotic relationship. The two organizations are "paper clipped" together through an intercompany agreement that gives the operating company the right of first refusal to lease and manage all future real estate acquired by the REIT, and provides the REIT with the right of first refusal to acquire property presented by the operating company. In addition, the two companies share senior members of management as well as board members. These arrangements fully align the two companies' interests for the benefit of both companies' shareholders (Beals \& Arabia, 2003).

\section{Evolution and Change-1980s}

The 1980s saw the slow emergence and recovery of REITs as viable investment vehicles. As can be seen in table 1, throughout the 1980s, there was a slow but steady increase in the market capitalization and number or REITs. In fact, in 1980, there were 
75 REITs with a total market capitalization of $\$ 2.2$ billion. However, by 1989 , this grew to a total of 120 REITs with a total market capitalization of $\$ 11.7$ billion. This growth was fuelled in part due to the fact that investors once again started to regain confidence in REITs as investment vehicles, and they once again started to grow in terms of popularity. In addition, investors also saw REIT stocks as greatly undervalued. This was due largely in part to the fact that once REITs lost their popularity, during the 1970s, many investors failed to revalue their older properties in the 1980s. In addition, most of the REIT managers at the time tended to adopt a rather conservative approach, in anticipation of a declining market (Edmunds, 1982).

Another important and significant change that occurred with REITs that helped it to once again gain prominence as a viable investment vehicle is the fact that, during this period, REITs reduced their debts, and mortgage REITs would only lend funds to construction and development entities that were deemed to sound and stable, and not risky (Chan et al., 2003).

The Economic Recovery Act of 1981 also had a significant impact on REITs as investment vehicles as it inadvertently assisted in the development of REITs. This Act was initially enacted to spur the United States economy. Essentially, the Act provided tax breaks for real estate investors by allowing operating loss pass through as well as shortened depreciation periods. These factors attracted investors and developers who wanted to take advantage of the high tax shelter as well as the generous tax right off. The Act also provided developers with the ability to pass off losses to investors. In addition, during this period, most real estate limited partnerships were sold for less than their net 
assets value, with the overarching assumption that there would not be any further decline in the value of the assets, and further that the limited life of the assets ensured that investors could obtain a capital gain once their life was terminated. This however, was not the case as it did not happen. As a result, several real estate limited partnerships were formed and a resultant major real estate boom ensued. At first, these real estate limited partnerships had a negative impact on the REIT industry as it caused an increase in competition for real estate investment capital. This once again created a situation where REITs were once more less popular, despite the fact that their annual average returns at the time (between 1981 and 1984) were more than 20\% (Chan et al., 2003).

In addition to the real estate limited partnerships, REITs also faced competition from another real estate development concept, the master limited partnership. This concept offered investors the liquidity and investment concept that REITs offered. In addition, they also offered the tax incentives that limited partnerships enjoyed. Further, these types of companies also provided mortgages, diversified equity real estate properties as well as specialized real estate assets such as hotels and restaurants. Thus, although compared to these real estate limited partnerships, the traditional REITs offered the ability of greater liquidity than the real estate limited partnerships. Yet, they were not especially attractive to investors during the early 1980 s.

Faced with this increased competition, the REIT industry responded by introducing a new REIT concept, the self-liquidating, finite-life REIT, which started to trade publicly during the 1980s. This type of REIT structure attempted to win investors over by informing investors that their assets would be liquidated within a finite time 
period, usually ten years. In addition to the existing benefits that the current REITs offered, the self-liquidating finite-life REITs offered an added advantage since these REITs could be liquidated or terminated if market conditions were not favorable for the REIT, and termination was in the best interest of the investor. This would therefore improve the chance that investors would obtain capital gains once the self-liquidating REIT assets were liquidated.

However, despite the implementation of these steps to allow REITs to be more competitive in the marketplace, the popularity of REITs as investment vehicles was once again saved through the direct intervention of the government, through the passage of legislation, the Tax Reform Act of 1986. In fact, the recovery and reemergence of REITs during the 1980s has be largely attributed to the passage of the Tax Reform Act of 1986 (Han \& Liang, 1995;Lee \& Lee, 2003) which transformed and enhanced REITs as competitive real estate investment vehicles by removing the advantages previously enjoyed by other tax driven investments (Han \& Liang, 1995). This Act has been credited in launching the second REIT "boom" phase as it once again altered the dynamics of real estate investing and signaled the emergence of REITs as bona fide investment vehicles. This Act eliminated the tax incentives offered by the Economic Recovery Act of 1981 (Kim, Gu, \& Mattila, 2002). Effectively, the Tax reform Act of 1986 eliminated all the tax advantages enjoyed by the real estate limited partnerships and the master limited partnerships (many of which were tax incentive driven developments ), thus creating more or less a level competitive playing field. For example, one of the major advantages that these structures had over REITs was their ability to use passive 
income losses from partnerships to offset gains in other active or active income. However, perhaps the most significant change that this Act brought about was the removal of the independent contractor rule, which previously prevented REITs from actively participating in the management of their properties. Instead, the provisions under the new Act allowed REITs to actively participate in the management and operation of their properties by allowing them to provide "customary services" to their tenants without the use of independent contractors. This new rule therefore allowed REITs to exercise greater management control over their properties.

This Act therefore eliminated the problem of leakage that had plagued the industry since the advent of the modern REIT in 1960. As discusses previously, leakage referrers to money lost by REITs when they utilize independent contractors, or agents to operate their properties. Hence, the Tax Reform Act of 1986 allowed for the first time the active management of properties by REITs as compared to passive management as was previously allowed under the pre Tax Reform Act of 1986. This Act also resulted in REITs becoming more fully integrated since having an internally managed company reduced conflicts of interests as the goals and objectives of the REITs could be carried out by the management team. Further, this also allowed for the goals of the REITs to be closely aligned with those of the shareholders, which ultimately results in a more efficiently run or operated REIT. The new laws also made REITs attractive by removing the 100 shareholder requirement as well as the 5/10 rule during the REIT's first taxable year of operation (Knight \& Knight, 1992).

Another key, significant and indirect consequence of the Economic Reform Act of 
1986 is that of structural changes within the REIT industry which were propagated by this Act. One such change that occurred as a result of this Act is REITs started to reduce their reliance on external advisors and became more company oriented in terms of their overall operations (Chan, Leung, \& Wang, 2005). For the first time, REITs were allowed to develop and manage their own properties, whereas previously, REITs were required to contract the operation of their properties to third parties. Thus, REITs had more flexibility and leverage in participating in the overall management of their assets is this less tax restrictive environment (Corgel et al., 1995). As a result, the real estate investment trust market began to show signs of slow growth during the latter half of the 1980s. As can be seen in table 1, during the period 1985 and to 1990, REITs remain somewhat stable in terms of their average size while market capitalization and total number grew from $\$ 7,674$ million to $\$ 8,737.10$ million, and 82 REITs to 119 REITs respectively.

In 1989, REIT growth, development and popularity as investment vehicles got an indirect boost when the Resolution Trust Corporation was created to assist the faltering saving and loans banks and other lending institutions. This action resulted in REIT shares being sold by banks that held these shares at a low price which attracted investors into the REIT market (Lee \& Lee, (2003), which resulted in the REIT market experiencing a Bull market starting in 1991 (Block \& French, 2002).

As REITs started to mature as viable investment vehicles, other changes in their structure were also noted. By the late 1980s REITs compared to their predecessors of the early1980s, were larger in size and were more liquid (Beneveniste, Capozza, \& Seguin, 
2001; Chan, Erickson, \& Wang, 2003). REIT portfolios of the late 1980s and beyond also tend to focused more on specific property types such as industrial, office, retail, residential, diversified lodging, self storage, health care, and specialty (Capozza \& Seguin, 2001) and had larger amount of inside ownership than their predecessors (Capozza \& Seguin, 2003). Most important in terms of their evolution, the REITS of the late 1980s and beyond progressed from their fund like structure and displayed characteristics similar to those of other firms trading on the stock market (Chan et al. 2005).

The passage of the Tax Reform Act of 1986 also resulted in a fundamental shift not only in the structure of REITs, but also in the types of investors who were attracted to REITs. Initially, when the Real Estate Reform Act was passed in 1960, the rules were designed specifically to attract small investors to participate in the real estate market (Chan et al., 2005). Hence, during the early period, there were relatively few institutional investors such as retirement funds and financial analysts actively participating in the REIT market, compared to the stock market as a whole. The reason for this is the fact that generally, institutional investors are usually attracted to and will invest in companies that are large, liquid and have a clearly defined and focused business line. The early REITs clearly did not display such characteristics. However, the passage of the Tax Reform Act in 1986 created the necessary changes that not only continued to attract small investors, but also institutional investors who welcomed the structural changes which were now desirable. As a result, over the past two decades, a significant amount of institutional investors have been attracted to REITs, as they see them as alternatives to 
direct real estate investment combined with the fact that the REITs market offers the added benefit of greater liquidity.

Maturity: The 1990s and Beyond

The start of the 1990s clearly mirrored the four decade history of REITs, decline followed by substantial growth. For example, as can be seen in table 1, the market capitalization of REITs fell from $\$ 11.6$ billion in 1989 to 8.7 billion in 1990 . This was due largely in part to the fact that by the late 1980s, the market was over supplied because of the large number of properties that entered the market by failed banks and savings and loans. This resulted in or caused real estate prices as well as REIT returns to be depressed. However, despite this rather slow start, the 1990s and beyond saw the exponential and unparalleled growth and maturity of REITs as stable investment vehicles, as investors once again regained confidence in their potential as viable investment vehicles. In fact, by 1998, the total number of publicly traded REITs had grown from 119 in 1990 with market capitalization of only $\$ 8.7$ billion to 210 , with a total market capitalization of $\$ 138$ billion. By 2005, the total number of REITs had grown to 197 , with a total market capitalization of $\$ 330.6$ billion. As can be seen in table 1 , the majority of growth occurred in the equity REIT segment of the industry. This segment increased from 58 in 1990, to 152 at the end of 2005. During the same period, the number of mortgage and hybrid REITs combined were 61 in 1990, however, by the end of 2005, there were only 45 mortgage and hybrid REITs combined (NAREIT, 2006). The decline in the number and capitalization of hybrid and mortgage REITs was 
attributed to the relatively lower returns of these types of REITs compared to the returns obtained from equity REITs. In addition, these types of REITs were also deemed to be extremely volatile compared to equity REITs. The poor performance of mortgage REITs was also attributed to high leverage combined with the types of properties that lending institutions were funding. Further, mortgage REITs had little incentives to prevent foreclosures or renegotiate loans to prevent foreclosures (Brown, 2000). As a consequence, several foreclosed properties were purchased by equity REITs, which obviously resulted in a decline in mortgage REITs, and an increase in equity REITs. Hence, low property prices propelled the growth of equity REITs.

Several government interventions in the form of legislations also contributed to the growth of the REIT industry during the 1990s as well. The first was the Omnibus Budget Reconciliation Act of 1993 (also called the Revenue Reconciliation Act of 1993) which, for the first time made REITs attractive to institutional investors such as pension funds. Prior to the passage of this Act, REITs were required to follow the 5/50 rule which stipulated that no fewer than five individuals could own more than $50 \%$ of all the combined outstanding shares of a REIT. This rule meant that REITs were not attractive to institutional investors such as pension funds since, these funds comprised the investment of several hundred or thousands of investors, who (under this rule) were essentially counted as one investor in REIT funds. The Omnibus Budget reconciliation Act of 1993 modified this rule and allowed pension funds to count each individual investor for the purpose of REIT investment, once the REIT had at least 100 investors. As a result, REITs with their high dividends yields became attractive to these institutional 
investors as well as investment banking firms.

The other significant change that accounted for the popularity and growth of REITs during the period was the development and introduction of the Umbrella partnership REIT (UPREIT) structure in 1992. This structure comprised two components- the REIT itself and the operating partnership. The REIT is the component that issues stocks to the public and owns properties while under the operating partnership relationship, the REIT usually owns or purchase an operating interest in a partnership. Hence, under this arrangement, REITs were allowed to own their properties indirectly through the operating partnerships (Beals \& Arabia, 2003).

The 1990s also marked the specialization of REITs by property types, namely, retail, hotels/lodging, apartments, offices and industrial properties, shopping malls, selfstorage properties etc. Along with this trend of REITs focusing on specific property types was also the fact that the management of REITs became more focused, specialized and increasingly more knowledgeable. Thus, during the 1990s and beyond, REIT properties as a whole were improved in their overall managerial efficiency and capabilities.

Another significant pair of legislations that had a positive effect of the REIT industry during the period was the REIT Simplification Act of 1997 and the REIT modernization Act of 1999. Amongst other things, the REIT Simplification Act of 1997 removed the requirement that a REIT cannot earn more than $30 \%$ of its gross income from the sale of assets that are not held as long term investments. The REIT modernization Act of 1999 which became effective in 2001 expanded on the REIT 
Simplification Act by allowing REITs to own taxable subsidiaries to provide services to their tenants without loosing their status as a REIT, which removed the problem of leakage previously encountered. In addition, the REIT Modernization Act reduced the amount of taxable earnings distribution requirement from $95 \%$ to $90 \%$.

\section{History and Evolution Summary}

Changes in the United States tax laws over the past four decades have significantly affected the growth and development of the REIT industry and have resulted in the industry becoming more viable and efficient as investment vehicles. These changes have resulted in REITs becoming more attractive as investment vehicles both to individual small investors as well as institutional investors. The REITs of today are therefore the direct creation of government legislations, and accordingly have evolved and grew as a result of changes in government legislations.

Since their inception over a century ago, the REIT industry and REIT structure have undergone significant changes and have evolved significantly to become the viable investment vehicles they are today. In recent years, most of the changes and modifications of current tax laws that have impacted REITs have resulted in this investment vehicle becoming more efficient, competitive and attractive. This is because, over a forty year period, these changes have effectively removed some of the burdensome and confusing rules, regulations and restrictions that existed during the early years of REIT development. In addition, REITs have become more specialized, and many have chosen to focus their managerial skills and expertise on particular segments of the REIT 
industry. It is this specialization that has enabled REITs to become more efficient.

As the popularity and efficiency of REITs have increased, they have attracted large institutional investors, such as pension funds. This shift in investors is revolutionary since, initially, REITs were developed to allow small investors to participate in the real estate market. In addition to the change in investors, the number of REITs within each REIT category has shifted as well. For example, in 1975, equity REITs accounted for only $26 \%$ of the overall REIT market while mortgage REITs accounted for $47 \%$. However, thirty years later, this ratio changed to $77 \%$ for equity REITs while mortgage REITS accounted for only $18 \%$. The market capitalization for both sectors has also changed significantly during the same period. In 1975, mortgage REITs accounted for $35 \%$ of the overall market while equity REITs accounted for $31 \%$. However, by 2005 , equity REITs accounted for $92 \%$ while mortgage REITs accounted for only $7 \%$ (percentages were calculated from the data presented in table 1).

As one examines the growth and evolution of REITs in the United States, it becomes clear that the evolution of REITS as viable investment vehicles in can be separated into three distinct "boom" periods. Following the passage of the Real Estate Investment Trust Act, the "first generation" of modern REITs was formed and did not gain prominence as investment vehicles until the late 1960's. This was due largely in part to the fact that the Federal Reserve Board increased interest rates in 1968 in an effort to reduce inflation (Mullaney, 1998). Although this action spurred the US economy, it prevented commercial banks from competing for investor's capital. Further, at the time, banks were restricted by law in what they could pay to attract deposits. As a 
consequence, many investors sought new ways to invest their money and sought higher paying money markets and bonds. This opened the door for REITs since banks which historically funded the construction industry could no longer do so because they had fewer deposits. This event therefore launched the mortgage REIT industry as shareholder funds were invested through direct lending to real estate projects as well as through the purchase of real estate portfolios. By 1968, there were three mortgage trusts, which sold seventy-three million dollars in new shares. REIT growth during this period was attributed to an increase in demand for construction and real estate development financing, which could not be met by existing financial institutions. As a consequence, mortgage REITs were developed to satisfy the unfulfilled need for financing (Han \& Liang, 1995).

By 1970, REITs had raised over one billion dollars (Mullaney, 1998). Thus, during the early stages of REIT growth, the majority of REITs were mortgage REITs which were developed to satisfy the need for commercial real estate financing. The growth of mortgage REITs continued until the mid 1970's when many became defunct because of poor management (which resulted in poor underwriting) and rising inflation which left mortgage REITs with no choice but to liquidate their assets. The fate of mortgage REITs was further worsened by the fact that the supply of commercial real estate exceeded the demand for commercial real estate. This resulted in many real estate investors defaulting on their loans since many commercial buildings went un-rented, leading to a decline in the value of mortgage trusts shares. These situations combined with escalating interest rates caused several real estate developers and investors to default 
on their loans and left them with no choice but to liquidate their assets (Corgel, McIntosh, \& Ott, 1995).

REITs continued to grow throughout the 1970's and were able to secure funding through stock and debt underwritings as well as from commercial banks. This growth during the 1970's was tempered by rising interest rates during the period as well as the 1973 oil crisis. As a consequence, REITs experienced negative returns of -29.35 per cent in 1974 and -49.82 per cent in 1975 (Lee \& Lee, 2003). REIT development was further affected by the decline in construction and development loans, which fell from 53 per cent of total assets in 1972 to six percent in 1984 (Lee \& Lee,2003). Further, as indicated in table 1 , the total market capitalization of REITs declined from $\$ 1,494.3$ in 1971 to all time lows of $\$ 712.4$ millions in 1974 and $\$ 899.7$ million in 1975 . This was somewhat a reversal of the general trend in the commercial banking sector as rather than compete with REITs, banks were now providing financing for REITS. As a consequence, bank loans rose from $11 \%$ of total REITs in 1969 to $56 \%$ of total REIT assets by 1974 (National Association of Real Estate Investments Trusts, 1978).

During the late 1960's and early 1970's, there was a substantial growth in the number of REITs. This growth was propagated by the fact that there was a large demand for financing to fund construction and real estate development. However, commercial banks at the time were unable to effectively fund and finance these ventures (Han \& Liang, 1995). As a result, REIT popularity grew within the capital market and they became an alternative source for financing real estate ventures. The result was that between 1968 and 1975, total REIT assets in the United State experienced a 2000\% 
increase (Haight \& Fort, 1987). Since most of the REITs in the 1970's were mortgage REITs, they were susceptible to the same negative leverage as their banking rivals which meant that when interest rates rose in the mid 1970's, their fixed rate loans declined in value. The effect on REITs was that many builders who had received REIT financing to start construction were unable to complete them and defaulted on their loans (New York Institute of Finance, 1988). As a result, thirty REITs became defunct, and the value of the industry as a whole declined from almost twenty billion to less than ten billion dollars, while the number of dividend paying REITS declined from 154 in 1973 to 68 in 1975 (New York Institute of Finance, 1988). In fact, this event damaged the reputation of the REIT industry and caused it to loose its prominence in the capital market community as a major force for the next twenty years (Beals \& Arabia, 2003).

The REIT industry did not recover until the 1980's when the second "boom" in the REIT industry occurred, due largely to the recovery of the real estate market. To spur the economy, the Economic Recovery Act was passed in 1981. This Act allowed for shorter depreciation schedules for real property as well as allowed for the pass through of tax losses to investors, who in turn were able to utilize those losses to reduce their personal income tax liabilities. This therefore favored partnerships more than REITS and as a result, over eighty billion dollars were raised by real estate limited partnerships during the 1980's (Mullaney, 1998). However, although REITs were not active players in the market at this time, they ultimately benefited from the situation. The reason for this is that The Economic Recovery Act created a situation where investors wanting to take advantage of the favorable conditions stipulated by the Act, quickly created a 
situation where the real estate market became overbuilt. This was worsened by the Gulf war which caused the United States economy to decline and left many real estate owners illiquid, defaulting on their debt service. Many owners had no choice but to recapitalize their holdings as REITs, thereby gaining liquidity and maintaining their assets and were able to enjoy the increase in their assets value towards the end of the decade. In fact, REIT shares acted as "currency" to exchange for distressed properties (Beals \& Arabia, 2003).

By the late 1970s and early 1980s, the REIT industry underwent significant structural-revise changes. For example, during the period, as indicated in table 1, average market capitalization of all publicly traded REITs doubled from $\$ 40.9$ million in 1972 to over $\$ 86$ million by 1984 . This period also marked the growth of the industry's stock market value which grew from $\$ 15.6$ billion in 1992 to $\$ 45$ billion by the end of 1994 . At the end of 2005, REITs had market capitalization in excess of $\$ 330$ billion (National Association of Real Estate Investment Trusts, Inc, 2006). On the negative side, this growth occurred despite the fact that leverage (short term debt) of REITs declined from $64 \%$ in 1972 to $55 \%$ in 1984 (Han \& Liang, 1995). Further, construction and real estate development loans declined from $53 \%$ of total assets in 1972 to only $6 \%$ in 1984 (Lee \& Lee, 2003).

The third and final distinct "boom" phase began in the early 1990s as many REITs began to go public and marked the exponential growth of REITs. This growth was driven by the fact that during the period, many savings and loans which held the mortgagers of several real estate investments were in demise. This boom has been 
attributed to several factors. The first was the Revenue Reconciliation Act which removed several barriers and made REITs more attractive especially to institutional investors such as mutual funds (Yobaccio, Rubens, \& Ketcham, 1995; Crain, Cudd, \& Brown, 2000) as well as portfolio diversification (Giliberto, 1990; Ori, 1995). The second reason is that investors saw the economic benefits to be derived by combining their resources and in the process obtain the benefits of commercial real estate investing (Han \& Liang, 1995). The final reason is that investors also perceived that REIT ownership would provide inflation hedging ability (Chatrath \& Liang, 1998).

The evolution and growth of REITs as viable investment vehicles continued in the 1990's with the passage of the of the REIT modernization Act in 1999. This Act was designed to enable REITs to compete effectively with other commercial real estate entities and other business formations. Prior to the passage of this Act, REITs were barred from providing services that were deemed to be beyond those classified as "usual and customary" within the industry. If a REIT violated this stipulation and provided services that were outside the boundaries of the classification of "usual and customary", then the income generated by the REIT would not qualify as income derived from a REIT, which meant that the REIT would therefore loose its REIT status. The REIT modernization Act also allowed for the REIT subsidiary companies to provide all services to their tenant or clients pay associated taxes and pass the earnings up to the parent REIT as income. The Act also reduced the required payout of gross income from $95 \%$ to $90 \%$, which meant that the extra five percent could be retained for entity growth. 


\section{TYPES OF REITS}

\section{Public REITs}

Real estate investment trusts exist in two broad categories, publicly traded REITs, which are those that are listed on an exchange or traded over the counter and private REITs which are those that are not listed nor traded publicly. Publicly traded REITs are further classified by their investment sector as equity real estate investment trust, mortgage real estate investment trusts, and hybrid real estate investment trusts. Equity real estate investment trusts are those that acquire property interest while mortgage real estate investment trusts are those that purchase mortgage obligations and consequently become a creditor with mortgage liens given to priority equity holders. Essentially, mortgage REITs owns mortgage paper secured by the underlying real property. Hybrid REITs are those that combine the advantages of both the mortgage REITs and the equity REITs.

The majority of equity REITs usually specialize in specific property types, and in some cases, they tend to focus their investments in specific geographic locations. This specialization is usually geared towards gaining competitive advantages by focusing resources on specific property types as well as within specific geographic areas. However, a small percentage of equity REITs chooses not to specialize, and instead choose to diversify their portfolios both in terms of property types and geographic locations. The National Association of Real Estate Investment Trusts (NAREIT, 2006) further classifies or breaks equity REITs down by property specialization or property sector. According to the NAREIT classification, equity REITs are classified according to 
the following property types:

Industrial/Office: Office building and industrial REITs are classified collectively as one segment since a substantial amount of REITs invests in both types of properties. This classification usually describes buildings that are used for the production or manufacture of products as well as properties whose functions is distribution or warehousing. Included in this category also are buildings that are used to house offices which are rented to tenants by the REIT. The National Association of Real Estate Investment Trust further divides this segment into REITs that own industrial, office, or a mix of office and industrial properties. These properties are often further dived based on their location such as whether they are located in the Central Business District or situated in suburban locations. Buildings may also be classified by subjective levels of quality. Under this classification, buildings are classified as class A, B, or C. Class A buildings are those that offer excellent location and access, the facilities are relatively new and in excellent conditions which allow the REIT to charge rents that are highly competitive. Class B buildings also offer good locations and are in good physical condition. However, they tend to suffer from some functional obsolescence and physical deterioration. Class $\mathrm{C}$ buildings are those that suffer from physical deterioration and functional obsolescence. Retail: These are REITs that focus on retail outlets. These REITs are further subdivided into those that own strip centers, regional malls, outlet centers, and free standing retail properties.

Residential: These are REITs that own residential dwellings consisting of five or more units in a single building or complex of buildings. These REITs are further subdivided 
into those that own multifamily apartments and manufactured home communities.

Diversified: These are REITs that own a portfolio of diversified property types.

Lodging/Resorts: These are REITs that own a variety of hotels, motels and resorts.

Health Care: These are REITs that specialize in owning hospitals and related healthcare facilities and are usually leaders to private healthcare providers who operate these facilities.

Self Storage: these are REITs that specialize in self storage facilities.

Specialty: Specialty REITs are real estate investment trust companies that specialize in various types of properties which include correctional facilities such as prisons, theatres, golf courses, automobile dealerships, and timberland.

Finite-Life REITs and Non-Finite Life REITs

In addition to the various categories of equity REITs discussed above, REITs can also be further classified and categorized by variables such as the duration of the trust such as finite-life REITs and nonfinite life REITs. Finite life or self liquidating REITs as they are commonly called are REITs that are formed with the goal being to dispose all the company's assets and distribute all proceeds to the company's shareholders by a specific date. Finite life REITs were developed in response to investor criticism that the prices of REIT shares act or behave like common stock in that the price is based on the current and expected future earnings rather than the real estate value of the REIT. By establishing a finite or terminal date, investors it is argued can make a better estimate of the terminal value of the underlying properties. Non-finite life REITs on the other hand operate as 
going concern entities. Most of today's REITs are non-finite life REITs.

\section{Private REITs}

Private REITs are real estate investment trust companies that are not listed on one of the established security markets. Although most of these companies are public entities, they are not listed on public exchanges or traded over the counter as most public REITs. This category of REIT is not registered with the Securities exchange Commission. The National Association of Real Estate Investment Trust classifies private REITs into three categories: (1) REITs targeted towards institutional investors; (2) REITs that are syndicated to investors as part of a package offered by a financial consultant; (3) “incubator" REITs which are REIT that are funded by venture capitalists who expects that the REIT will develop and garner an excellent track record to launch a public offering in the future.

\section{Unlisted REITs}

A third and relatively new segment of REITs are those that are classified as unlisted REITs. This segment of REITs file with the Security Exchange Commission, however, their shares do not trade on public national stock exchanges. Unlike publicly traded REITs, which offer a high level of liquidity, unlisted REITs usually require a minimum holding period. Exit strategies for investors are usually linked to a required liquidation after some period of time (usually ten years). Although opponents of unlisted REITs argue that from the perspective of investors, they are expensive and illiquid when compared to publicly traded REITs, proponents argue that while this may be true, they 
are not subjected to the market volatility that publicly traded REITs are subjected to (Brueggeman \& Fisher, 2005).

\section{THE LEGAL STRUCTURE OF REITS}

\section{Legal Requirements}

Real estate investment trusts are real estate companies that choose to qualify under a set of tax provisions established by the Internal Revenue Code. Compliance with these set of tax provisions enable the company to become a pass-through entity that distributes a substantial amount of its earnings in addition to any capital gains that is generated from the disposition of its assets to its investors. REIT taxation is govern under Internal Revenue Code Section 856-858, which requires all real estate investment trust meeting the tax requirements to qualify as a REIT to act as a conduit with respect to income distributed to beneficiaries of the trust. The tax provisions under which REITs are established specifies that REITs do not pay taxes on its earnings. However, the earnings distributed represents dividend income to shareholders and are taxed accordingly. Thus, REIT corporations are not taxed on distributed taxable income when it qualifies for the special tax benefit. In addition, all capital gains are taxed at the shareholder's applicable rate. Real estate investment trusts have characteristics that are similar to those of mutual funds and by law are not required to pay corporate income taxation on earnings distributed to shareholders. Thus, if an entity qualifies as a REIT, it does not pay corporate taxes, which means that REITs do not have the double taxation experienced by $\mathrm{C}$ corporations. 
While the favorable tax treatment has made REITs attractive as investment vehicles, in recent years this benefit has come into question. For example, Gyourko \& Sinai, (1999) argued that the net tax benefit of REIT structures is between 2-5 percent of the industry market capitalization. Further, they argued that because real estate that is owned by individuals or owned through partnerships is also not taxed at the corporate level, the REIT structure has no tax advantage compared to private unincorporated holdings (Gyourko \& Sinai, 1999).

\section{Asset requirements}

At least 75 percent of the value of a REIT's asset must consist of real estate assets, cash, and government securities. This means that unlike $\mathrm{C}$ corporations, REITs do not have the freedom to own or mange any type of assets (Kim, Gu, \& Mattila, 2002).

- No more that 5 percent of the value of assets may comprise securities of any one issuer if the securities are not includable under the 75 percent test.

- REITs cannot hold more than 10 percent of the outstanding voting securities of any one issuer if those securities are not includable under the 75 percent test.

- No more than 20 percent of the REIT's assets can consist of the stocks of taxable REIT securities.

\section{Income Requirement}

- At least 75 percent of gross income must be derived from rents, interest on obligations secured by mortgages, gains from the sale of certain assets, or income 
attributable to investments in other REITs.

- No more than 30 percent of the REIT's gross income can be derived from the sale or disposition of stock or securities held for less than six months or real property held for less than four years except for property involuntarily converted or foreclosed on.

\section{Distribution Requirement}

- At least 90 percent of REIT's taxable income (this was changed by the REIT modernization Act of 1999 from 95\%) must be distributed to shareholders on an annual basis. This means that in order for REITs to expand, they must seek external funding sources since they do not retain the majority of their income (Beals \& Arabia, 1998).

\section{Stock and Ownership Requirement}

- The REIT must be structured as a corporation, business trust, or similar association. The REIT must be taxable as a corporation.

- Must be managed by a board of directors or trustees.

- Be an investor in real estate, as opposed to a broker.

- Shares in the REIT must be fully transferable and must be held by a minimum of 100 persons, with no more than five of these owning more than a combined $50 \%$ of the trust's outstanding shares (the " $5 / 50$ rule").

- No more than $50 \%$ of a REIT's shares may be held by five or fewer individuals 
during the last half of a taxable year.

\section{REIT Status Termination and Penalties}

If a REIT fails to comply with the real estate investment trust qualifying requirements, or if it decides to terminate its status as a REIT, then the corporation will effectively terminate its status to be taxed as a REIT in subsequent years. Once a company loses its status as a REIT, it cannot elect to be taxed as a REIT until a period of five years has passed after the termination date. However, if the company's status as a REIT was terminated because of failure to comply with the qualifying requirements, it has the opportunity to regain its status as a REIT within the five year time frame if it can prove to the Internal Revenue Service that its failure to comply was due to reasonable cause and not because of willful actions or neglect. Other penalties for compliance failures include disqualification of a portion of the REIT's earnings from tax-exempt treatment at the corporate level.

\section{REIT TAXATION AND DIVIDENDS}

By law, REITs are not required to pay federal or most state income taxes. However, to receive this exemption, the current law requires that a REIT payout 90 percent of its earnings in the form of dividends to its shareholders. These dividends are taxable to the individual investor. Hence, this special tax treatment allows REIT shareholders to avoid the double taxation that is usually associated with normal corporations. 
The high and required dividend payout leads to one of the most important investment characteristic of REITs. They usually have yields that are well above average and are excellent investments for investors seeking high income. REITs also have the added advantage in that they enjoy the high liquidity of publicly traded stocks. This is important since direct investment in real estate is not liquid. For example, while stocks in REITs can be traded or sold at a moment's notice, the same cannot be done with real property. Thus, REITs investors benefit from the liquidity of owning the real estate via REITs.

Although the tax exemption is attractive for investors, it has its drawback. Corporations generally retain a substantial portion of their income to reinvest in the business, which allows the company to grow. However, the fact that REITs are required by law to pay out $90 \%$ of their taxable income means that only a small portion of the company's income is left for reinvestment purposes. Growth can therefore occur only through the selling of new share in the company, which means that the ownership of the current shareholders is diluted which also means that the individual shareholder does not benefit from this growth in terms of stock appreciation (stock appreciation may occur in the long run). Hence, it follows therefore that REITs should be considered as income vehicles rather than as growth stocks.

\section{MANAGEMENT OF REAL ESTATE INVESTMENT TRUSTS}

The majority of REITs are managed actively as operating companies and the management of the real estate is usually undertaken either internally by the REIT or 
externally by a management company that works for the benefit of the REIT shareholders. REITs usually invest in specific geographic areas and in specific property types since this specialization allows REIT shareholders to benefit from the specialize expertise of the management company and its management team.

Prior to the passage of the Economic Reform Act of 1986, there were management restrictions of REITs which ensured that the management of REITs was passive, and not active. As a result, trustees, directors and other REIT employees were not allowed to actively engage in managing or operating REIT properties, providing services to REIT tenants, or even collecting rent from tenants of REIT properties. Instead, these services were contracted out to independent entities. However, the passage of the Economic Reform Act in 1986 relaxed this restriction, making it possible for REITs to offer normal maintenance and customary services for tenants, which effectively eliminated the need for such services to be undertaken by outside, independent contractors. Thus, the passage of this Act meant that for the first time, REITs could internalize such functions, thereby creating vertically integrated operating companies, which altered REITs as investment vehicles.

Prior to the passage of the Economic Reform Act of 1986, most REITs were organized or sponsored by financial institutions such as insurance companies, commercial banks, or mortgage bankers. This sponsoring institution also provided advising services to the REIT directly or indirectly through affiliates. Advisors were also charged with the responsibility of managing the operations of the REIT, which included providing services such as the management of the REIT assets as well as its liabilities. 
Once this Act was passed in 1986, REITs became more attractive especially for real estate developers who previously were not interested in passive real estate investment. This Act also resulted in a fundamental shift in REIT ownership, as real estate developers became the major sponsor of REITs. The reason for this shift is that real estate developers could now provide the internal management and advising required to maximize the return on their investment. Thus, as a result of the 1986 Act, today's REITs have active and not passive management, which has made them attractive to investors. Hence, most of the REITs today are self advised, vertically integrated operating companies that actively mange their portfolios, with the ultimate goal being cash flow and portfolio growth. This Act therefore marked a fundamental shift from the previous structure of passive management.

\section{THE APPEAL OF REITS AS INVESTMENT VEHICLES}

Several reasons have been forwarded as to why REITs appeal to investors as viable investment vehicles and have consequently led to their increased popularity and securitization in recent years. While some researchers have attributed this increased in popularity to factors such as the overall increase in demand for real estate securities by investors as well as the increase in the supply of real estate available for securitizations (Crain, Cudd, \& Brown, 2000), others have argued that the appeal of REITs as investment vehicles is partly due to their ability to act as hedge against inflation (Chatrath \& Liang, 1998). The assertion that REITs act as hedge against inflation has, however been met with mixed reactions (Hartzell, Hekman, \& Miles, 1987; Chan, Hendershott, \& 
Sanders, 1990; Chatrath \& Liang, 1998). However, despite these mixed findings, the perception that REITs provide a hedge against inflation has also added to the popularity of REITs a viable investment vehicles. However, other reasons that account for their appeal as viable investment vehicles have been met will less debate. Below are the less debatable common reasons that account for the appeal of REITs as viable investment vehicles.

REITs have become attractive investment vehicles since they offer both small and large investors the opportunity to invest directly or indirectly in real estate. Hence REITs are often considered as substitutes or a viable alternative to directly investing in real property (Venmore-Rowland, 1989). Essentially, real estate investment trusts allow investors with limited capital the ability to invest in real property stocks as a way of gaining property exposure without the introduction of excessive illiquidity (Liow, 1997). Thus, individual investors can indirectly acquire real estate investment through the purchase of publicly traded shares in REITs or for larger investors, through the process of directly acquiring real property or through lending as in the case of mortgage REITs. Further, the fact that large amounts of resources and expertise are required for the financing and ownership of commercial real estate, effectively exclude many investors from directly participating in the acquisition or investing in commercial real estate market. REIT ownership however does not require large financial outlay nor the long term commitment required of commercial real estate investment, and hence allows small investors the opportunity to participate in the real estate market. Additionally, because most shares of REIT stocks are traded publicly, they are easily transferred from one 
owner to another at relatively low transactional costs. The end result is that investors, especially small investors can collectively combine or pool their resources and participate in the real estate market, thereby obtaining both real estate ownership and the economic benefits offered by commercial real estate investments (Han \& Liang, 1995).

Real estate investment trust are also attractive since compared to other equity investments, such as partnerships, they offer investors the added benefit of a greater level of liquidity, while at the same time allow them to earn a relatively high return on their investment. This is because, unlike most investments, by law, REITs are required to disburse ninety percent of their gross income to shareholders on annual basis. Hence, REIT investors can look forward to reliable and significant dividends which are typically four times higher on average than those of other stocks. Investors can therefore build greater long-term wealth by combining REIT stocks with other investments such as home ownerships as part of a diversified investment portfolio. Additionally, REITs are also attractive to investors since this investment vehicle allows them to benefit from the single taxation nature of REITs earnings.

REITs also offer investors the opportunity to invest funds in a diversified portfolio of real estate, with the assurance that their investment will be monitored and managed by a professional team. Thus, REIT investors own equity shares on organized exchanges which provide more liquidity as compared to acquiring real property. Further, since investors have the opportunity to pool their resources with individuals that have similar interests, funds are usually acquired relatively quickly to purchase real property in whatever portions that appears to yield the best returns for investors. This is because real 
estate development companies can circumvent creditors by securing financing through equity capital by forming publicly traded REITs (Gyourko, 1994).

Another factor that has accounted for the popularity of REITs is an important structural change of REITs that occurred with the introduction of the Umbrella Partnership REIT (UPREIT) in 1992 (Mullaney, 1998). This type of REIT was designed to allow real estate owners who are interested in taking their real estate operations public the opportunity to do so without incurring the exorbitant and often prohibitive capital gains taxes that were typical before this structure was allowed.

REITs have also grown in popularity because of the interest and investment of institutional investors (largely propagated by the tax changes brought by the Revenue Reconciliation Act of 1993), who now see REITs as viable investment vehicle. Prior to the passage of this Act, REITs had to comply with a tax provision referred to as the "five or fewer rule". This tax stipulation stated that an entity would loose its status as a REIT if more than 50 percent of the REIT's shares were held by five or less shareholders during the last half of a taxable year (Crain et al., 2000). This restriction therefore prevented several institutional investors, such as pension funds from actively investing in REITs. This is because, prior to the passage of the Act, institutional investors were regarded as single investors for the purpose of the "five or fewer rule". Since most REITs have a relatively small market capitalization, it was virtually impossible for large institutional investors to obtain investment positions within REITs without violating the "five or fewer rule". Once this barrier was removed, investment activities by institutional investors increased (Chan, Leung, \& Wang, 1998). The growth of real estate investment 
trust was also propagated by the fact that during the mid 1990's, both external equity and as well as debt financing were easily available to REITs (Mooradian \& Yang, 2001)

Since the passage of the Real Estate Investment Trust Act of 1960, the REIT industry has undergone a tremendous and dramatic growth, both in size and importance, especially during the last decade. This growth has been recognized by leading financial markets and institutions. For example, in 2001, Standard \& Poor's recognized the evolution and growth of the REIT industry as a mainstream investment by adding REITs to its major indices, including the S\&P 500 (NAREIT, 2006).

\section{LODGING REITs}

Since their introduction to the public in 1993, lodging or hotel REITs as they are sometimes called, have grown significantly in terms of numbers, from two at the start of 1993 , to a total of nineteen at the end of 2005 , and capitalization, from $\$ 100$ million $(\mathrm{Gu}$ \& Kim, 2003), to an estimated equity market capitalization of $\$ 17,617,000,000$ (National Association of Real Estate Investment Trusts, 2006). This growth has both increased the cash flow into the lodging industry while at the same time changed the real estate ownership structure within the lodging industry (Kim, Gu, \& Mattila, 2002). The growth of this equity REIT sector has occurred despite the fact that the proportion of unsystematic risk in the total risk of lodging REIT stocks were found to be $84 \%$ (Kim et al.), which exceeds the United States national average by 14\% (Gu \& Kim, 1998).

Lodging REITs also account for an estimated $5 \%$ of the NAREIT equity index (Imperiale, 2002) and 5\% of United States hotel real estate (Kim et al., 2002). 
Gu et al. (2003), suggest that there are four reasons that account for the growth of hotel REITs in terms of their absolute numbers as well as their market capitalization. First, the Revenue Reconciliation Act of 1993 included legislations that eliminated tax hurdles, thereby making sizeable investments in equity REITs such as hotel REITs more attractive to institutional investors. The second reason suggested by Gu et al. (2003) is the fact that the hotel industry rebounded in 1992 from depressed occupancy rates brought on by the wanton real estate overbuilding in the previous decade, which caused the lodging industry's average occupancy level to decline from $70.6 \%$ in 1980 , to under $62 \%$ by 1989 (Mullaney, 1998). In addition, the economic recession which affected the United States economy between 1991 and 1992 also caused occupancy and average room rates to decline. Once the recession was over, hotels once again became profitable as average occupancy and average daily rate rose steadily after 1993 . In fact, between the end of 1992 and the end of 1996, demand for hotel rooms increased by more than $2.5 \%$ annually. As a result of this improved performance, hotel REITs were the most financially rewarding investments in the REIT marketplace for the years 1995 and 1996 (Mullaney, 1998).

The third reason cited was based on investment decision making. According to Gu et al. (2003), prudent investors viewed REITs as a way of combining financial resources and in so doing, profit from the benefits of commercial real estate investment. In the process, such investors inadvertently contributed to the growth of hotel REITs. Knight \& Knight (1993), accentuated this point by arguing that hotel investors purchased ownership in hotel REITs with the intent that share values would continue to grow 
because of the constant flow of dividends and property value increases. Knight et al. (2003), further argued that the notion also existed amongst hotel investors that as REITs became profitable, the dividends generated could be reinvested in the company, thereby increasing each investor's stock value.

The final argument purported by Gu \& Kim, (2003) for the rapid growth of lodging REITs during the 1990s and beyond was the fact that investors perceived REITs on a whole as providing investments that would offer them inflation-hedging abilities. This argument is supported by other researchers (Chatrath \& Liang, 1998; Yobaccio et al., 1995) who also noted that REITs are attractive because they enable investors to diversify their portfolios (Giliberto, 1990; Ori, 1995; Grissom, Kuhle, \& Walther, 1978).

Despite the emergence of lodging REITs since 1993, momentum and growth did not take place until 1995, when the Chief Executive officer of Starwood Capital, Barry Sternlicht acquired Hotel Investor's Trust, which at the time was one of four pairedshared or stapled REITs structures that predated the 1984 ban by Congress of this type of REIT. In June 1994, Hotel Investors Trust was purchased by Starwood Capital and merged to form Starwood Hotels and Resorts Trust. Prior to this acquisition, Hotel Investors Trust had recorded a series of losses between the years 1991 through 1994. However, once the merger and creation of Starwood Hotels and Resorts was formed, there was an immediate financial turnaround. In fact, in 1995 and 1996, Starwood's annual returns of $77.9 \%$ and $93.2 \%$ represented the highest of all major equity REITs (Pablo, 1996). Thus, Starwood Hotels and Resorts heralded the emergence and prominence of lodging REITs. The company quickly expanded to acquire and include 
Westin, Ciga, and ITT which included Sheraton, Dessert Inn, and Caesars. Other lodging companies such as Patriot American Hospitality quickly realized the overall potential of the paired shared structure and formed their own REIT. Although the United States Congress outlawed the paired share structure, several other lodging companies took advantage of this paired share structure.

Prior to the identification of this possibility, hotel companies were reluctant to convert to REITs as they were plagued by the problem of leakage of revenue, since the "passive" component of the REIT requirement essentially prevented REITs from managing their own hotels. The REIT structure was also not particularly conducive or attractive to hotels since the significant fix costs of hotel operation, high operating leverage and high financial leverage meant that profits in the hotel industry are difficult to maximize. In addition, there is always a constant need to return capital into the entity to upgrade facilities. These factors combined with the problem of "leakage" meant that prior to the identification of the stapled structure as being applicable to the hotel industry REITs were not seen as conducive to the hotel industry. Table 3 presents a summary of the current lodging REITs (December 200), and includes the type of REIT structure, the number of properties owned, their trading ticker, the number of guestrooms as well as their market capitalization at the end of 2005 . 
TABLE III

LODGING REITS-DECEMBER 2005

\begin{tabular}{|c|c|c|c|c|c|}
\hline REIT Names & $\begin{array}{l}\text { REIT } \\
\text { Type }\end{array}$ & $\begin{array}{c}\text { Number of } \\
\text { Properties } \\
\text { Owned }\end{array}$ & Ticker & $\begin{array}{l}\text { Number of } \\
\text { Guestrooms }\end{array}$ & $\begin{array}{c}\text { Market } \\
\text { Capitalization }\end{array}$ \\
\hline $\begin{array}{l}\text { Ashford Hospitality } \\
\text { Trust }\end{array}$ & Equity & 33 Hotels & AHT & 5,095 & $\$ 674.92$ \\
\hline $\begin{array}{l}\text { Boykin Lodging } \\
\text { Company }\end{array}$ & Equity & 21 Hotels & BOY & 5,820 & $\$ 189.61$ \\
\hline $\begin{array}{l}\text { Diamond Rock } \\
\text { Hospitality Company }\end{array}$ & Equity & 7 Hotels & $\overline{\mathrm{DRH}}$ & 2,357 & $\$ 1,090.68$ \\
\hline $\begin{array}{l}\text { Eagle Hospitality } \\
\text { Properties Corporation }\end{array}$ & Equity & 12 Hotels & EHP & 3,243 & $\$ 175, .77$ \\
\hline Equity Inns, Inc. & Equity & 123 Hotels & ENN & 14,788 & $\$ 868.36$ \\
\hline $\begin{array}{l}\text { FelCor Lodging Trust } \\
\text { Inc }\end{array}$ & Equity & 130 Hotels & FCH & 37,000 & $\$ 1,301.91$ \\
\hline Hersha Hospitality Trust & Equity & 29 Hotels & HT & 2,981 & $\$ 191.57$ \\
\hline $\begin{array}{l}\text { Highland Hospitality } \\
\text { Corp. }\end{array}$ & Equity & 24 Hotels & $\mathrm{HIH}$ & 7,381 & $\$ 732.17$ \\
\hline $\begin{array}{l}\text { Hospitality Properties } \\
\text { Trust }\end{array}$ & Equity & $\begin{array}{l}\text { N/A-Invests in } \\
\text { REITs that } \\
\text { own hotels. }\end{array}$ & HPT & N/A & $\$ 3,093.33$ \\
\hline Host Hotels and Resorts & Equity & 103 hotels & HMT* & 54,000 & $\$ 10,666.29$ \\
\hline Innkeepers USA Trust & Equity & 70 hotels & KPA & 8,825 & $\$ 700.50$ \\
\hline LaSalle Hotel Properties & Equity & 26 Hotels & LHO & 8,300 & $\$ 1,685.91$ \\
\hline $\begin{array}{l}\text { MerStar Hospitality } \\
\text { Corp. }\end{array}$ & Equity & 73 Hotels & MHX & 20,319 & $\$ 921.1$ \\
\hline PMC Commercial Trust & Hybrid & $\begin{array}{l}\text { N/A-Loans \& } \\
\text { commercial } \\
\text { properties. }\end{array}$ & PCC & N/A & $\$ 140.72$ \\
\hline $\begin{array}{l}\text { MHI Hospitality } \\
\text { Corporation }\end{array}$ & Equity & 6 Hotels & $\mathrm{MDH}$ & N/A & $\$ 61.68$ \\
\hline $\begin{array}{l}\text { Strategic Hotel Capital, } \\
\text { Inc. }\end{array}$ & Equity & 16 Hotels & SLH & N/A & $\$ 1,618.30$ \\
\hline $\begin{array}{l}\text { Sunstone Hotel Investors } \\
\text { Inc. }\end{array}$ & Equity & 60 Hotels & $\mathrm{SHO}$ & 17,333 & $\$ 1,618.65$ \\
\hline Supertel Hospitality Inc. & Equity & 76 Hotels & SPPR & N/A & $\$ 76.25$ \\
\hline Winston Hotels & Equity & 42 Hotels & WXH & N/A & $\$ 295.39$ \\
\hline
\end{tabular}

Source: National Association of Real Estate Investment trusts, December 2005

PERFORMANCE OF REAL ESTATE INVESTMENT TRUSTS 


\section{REIT Performance as Investment Vehicles}

Since their formal introduction as viable investment vehicles in the 1960's, several studies have been conducted relating to how REITs perform as investment vehicles. In fact, as REITs began to grow in prominence as viable investment vehicles, the amount of research pertaining to their performance has grown steadily since the latter part of the 1970's, and have consequently enabled investors to better understand how REITs perform as investment vehicles under different conditions.

Generally, studies examining REIT performance are divided into various time periods. First and foremost are those that examined the performance of REITs over the short term (periods less than ten years) and those conducted to examine performance over the long term (periods of ten or more years), the most comprehensive of which appeared in Han \& Liang (1995). Using the traditional Jensen model, Han \& Liang, (1995) found that REIT performance was similar to the market during the period 1970-1993. They also found however that REIT performance was however not stable over time $\mathrm{Li} \&$ Wang, (1995). They also found however that REIT performance was however not stable over time. However, Li \& Wang, (1995) also in their examination of equity real estate investment trusts and mortgage real estate investment trust performance over a twenty year period and found that REIT returns were more predictable than stock returns.

Still, other researchers have examined the long term qualitative aspects of the REIT markets such as appropriateness of REITs for certain investors (Bergsman, 2001; Haddock, 1998; Zell, 1998). Other studies examined REIT performance for shorter periods. Brounen, Eicholtz, \& Kanters, (2000) examined equity real estate investment 
trusts between the period 1993-1999 and found that real estate investment trusts have a high market capitalization. Still, other researchers have focused on the predictability and volatility of REIT returns versus returns from stocks and the inflation hedging ability of REITs versus stock investments (Chatrath \& Liang, 1998).

Previous research on real estate investment trusts have also focused on the use of several different measures of investment performance. Several research have focused primarily on the factors that affect or influence REIT returns using performance measures that are risk adjusted (Goebel \& Kim, 1989; Howe \& Shilling, 1990). Other researchers have focused on comparing real estate investment trust performance to common stock and as well as real estate investments (Kuhle, 1987; Giliberto, 1990; Martin \& Cook, 1991). Still, others have focused on applying models such as the Capital Asset Pricing Model (CAPM) to ascertain the economics factors that affect REIT performance (Chan, Hendershott, \& Sanders, 1990) while others have focused on the use of models such as the Jensen model to ascertain the relative performance of real estate investment trusts.

Overall, researchers have presented divergent views as it pertains to REIT performance especially when compared to the stock market portfolio. On one hand, REITs, most notably equity REITs have been found to outperform the stock market portfolio (Kuhle, 1987;Sagalyn, 1990), while other findings suggest contrary viewpoints, and in fact have found that compared to the stock market portfolio, REITs have performed worse (Titman \& Warga, 1986; Goebel \& Kim, 1989).

Han \& Liang, (1995) suggested that one plausible explanation for such inconclusive findings on REIT performance is that the REIT industry is subject to periods 
of boom and bust, and several studies on REIT performance only cover relatively short time periods. Additionally, Han \& Liang (1995) further noted that in addition to the short time period covered by researchers in ascertaining REIT performance, some researchers only include survivor REITs in their studies. Sagalyn (1990) suggests that this approach of using survivor only REITs to ascertain the relative performance of REITs might be flawed since it could potentially be biased. A further weakness highlighted by Han \& Liang (1995), in conducting REIT performance related studies is the fact that researchers have consistently used the S\&P 500 composite index as a benchmark to ascertain the relative performance of REITs. The downside to using the S\&P 500 as a benchmark is that it contains large capitalization stocks while most REITs are small capitalization stocks. The issue of survivor bias and the choice of performance benchmarks were addressed by Han \& Liang (1995), who conducted a study to examine the performance of REITs over a twenty-three year period. Using the Jensen Index, an absolute measure of performance, which measures performance based upon a more realistic benchmark of a portfolio that invests in savings account and the stock market. Hence, in their study, the authors attempted to create an unbiased portfolio that is survivor free. Overall, they found that REITs performed similar to portfolios consisting of three month Treasury bills as well as stock market portfolios. During the examination period, REIT performance was found to be unstable. However, equity REITs, were found to perform better than mortgage REITs. Han \& Liang (1995) further concluded that short term performance do not effectively predict REIT performance in subsequent periods. Further, the authors found that the S\& P 500 index as well s the survivor REIT samples generally tend to 
overstate overall REIT industry portfolios, especially when compared to the stock market portfolio. This is because, as stated earlier, the S\&P 500 excludes small stocks while the use of survivor samples yield performance estimates as compared to an unbiased sample. This point was accentuated by Block \& French, (2002) who argued that because market indices such as the S\&P 500 exclude the smaller firms from the indices, they do not effectively capture the essence or performance of the market accurately. Further, market indices such as the S\&P 500 are value weighted indices. Block \& French(2002) proposed that using value weighted indices to measure the performance of publicly traded investment vehicles does not yield a complete picture of the investment performance since the investment itself my not be value weighted. Weighted measures of performance should be used to account for the effects of both small and large firms on (portfolio) performance. To overcome this weakness, Block \& French, (2002) argued that multiple index models such as two index models better explain the performance of investments, since they clearly identify those that outperform an underperforms the market. They also found that investment performance that is based on using one value based performance benchmark measure may not give an accurate picture of the actual performance of the investment. Instead, they argue that two-factor models should be used (Block \& French, 2002).

\section{Lodging REIT Performance}

Despite having the having the highest return (income and long-term returns) volatility of all REIT property sectors (Imperiale, 2002;Mueller \& Anikeeff, 2001), on a 
long term basis, the overall performance of lodging REITs has been one of the best, compared to other REIT asset classes (Imperiale, 2002). However, despite such assertions, little research has been conducted to empirically examine the long term performance of lodging REITs. Since their introduction to the public in the 1990s, few studies have been conducted to examine the overall performance of lodging REITs. Existing lodging REIT performance studies have examined performance from different perspectives and have all been short-term (less than a ten year period). Below is a brief overview of the most notable lodging REIT performance studies undertaken to date.

In a previous study on the performance of lodging REITs Kim, Mattila, \& Gu, (2002), examined the performance of lodging REITs between the period 1993-1999 (short term measure). In their study (2002), they applied the Jensen Index (Jensen, 1968) of performance measure to examine the overall performance of lodging REITs relative to the market portfolio, using one way analysis of variance, (ANOVA) and the Tukey multiple comparison to examine REIT performance compared to other REIT sectors. Their (Kim, Mattila, \& Gu, 2002) study findings revealed that overall, lodging REIT performance was similar to that of the overall REIT portfolio as well as the market portfolio. However, when compared to other types of REITs, lodging REITs' performance was found to be inferior to that of other types, namely, office, industrial, residential and diversified REITs. Interestingly, the study found that lodging REITs performed similar to health care and retail (Kim et al., 2002). As mentioned, the study examined lodging REIT performance over a seven year period. However, Han \& Liang, (1995) cautioned that examining the performance of REITs over relatively short time 
periods could yield inconclusive results since the stock market is susceptible to periods of booms and bust. It is especially important that lodging REIT performance is examined for longer periods due to the cyclical nature of the lodging industry as well as its sensitivity to events in the macro environment such as economic downturns.

The study (Kim et al., 2002) also examined the performance of lodging REITs against only one benchmark, the NYSE index. The authors argued that the NYSE index was used as a benchmark since thirteen of the nineteen REITs examined in the study traded on the NYSE. Han \& Liang (1995) also suggested that multiple benchmarks should be used to measure REIT performance so that REIT performance can be examined against both small and large companies.

Other lodging REIT performance studies include Sarheim's (2006), examined the performance of lodging REITs compared to C-Corporations and the S\&P 500 during the period 2000 to 2005 period. This was a period during which the U.S. lodging industry was affected by several significant events, namely, a weak economy in 2000 , the terrorist attack in 2001, the SARS epidemic and the Iraq war. Overall, lodging REITs were found to be resilient during this period. Other related lodging REIT performance studies include Kim et al. (2002), who examined the risk features of hotel REITs and Gu \& Kim (2003), who examined the financial variables that affect hotels REIT's unsystematic risk.

\section{MEASURING AND BENCHMARKING INVESTMENT PERFORMANCE}

The issue of selecting the appropriate measure of investment performance and benchmark remains strongly debated. Much of this debate has surrounded the use of the 
appropriate benchmark against which to measure return on investment. Despite advances in technology and the application and the invention of advance modeling techniques, the debate has continued in investment circles for over three decades. Friend, Blume, \& Crockett, (1970) noted that in evaluating performance, caution should be exercised in using benchmarks that "fools" the alpha calculation by either overweighing or underweighting the returns of small firms. The importance of benchmark selection, investment survivability and the importance of non-CAPM return generating factor when measuring performance is also emphasized (Han \& Liang, 1995; Admati, Bhattacharya, Pfleiderer, \& Ross, 1986; Kent, Grinblatt, Titman, \& Wermers, 1997;Lehmann \& Modest, 1987). Block \& French, (2002) noted that since stock indices such as the S\&P 500, which are commonly used as benchmarks against which to measure performance are value weighted, their use of evaluating the relative performance of non weighted returns may not accurately indicate performance.

Other methods traditionally used to evaluate returns include those that are classified as risk-adjusted performance measures. Generally, there are three indices that are used to measure the risk adjusted performance of portfolios. These are, the Treynor index (Treynor, 1965), the Jensen index (Jensen, 1968) and the Sharpe index (Sharpe, 1966). Of the three, the most common and widely used risk adjusted performance measure method for risk-adjusting returns are those that are based on Jensen's alpha (Jensen, 1969), which is generally used to measure whether or not a portfolio over performs or underperforms compared to the established stockbroker benchmarks (Han \& Liang, 1995;Kim et al., 2002). In addition, unlike the Sharpe and the Treynor indices, the 
Jensen Index allows for the testing of whether or not the abnormal return of a portfolio is statixtifically significant relative to the overall market (Asbere, Kleiman, \& McGowan, 1991). However, despite the fact that the Jensen's model has been used to measure investment performance, in recent year, the model has been subjected to various criticism. One of the arguments against the use of the model to evaluate performance is that the model uses only the market portfolio or one benchmark index (Block \& French, 2002). Other researchers such as (Fama \& French, 1993) argue that a two or three factor model would yield a more accurate measure of investment performance. Another criticism of the Jensen Index is that it assumes that investors have a diversified portfolio and further that the choice of the market index is important in the measuring of a portfolio's performance (Haugen, 2001).

However, despite the criticisms of the Jensen Index, it has been has extensively used in prior studies to measure the performance of REITs (Goebel \& Kim, 1989; Cannon \& Vogt, 1995; Han \& Liang, 1995; Howe \& Shilling, 1990 ; Sagalyn, 1990; Kim et al., 2002; Block \& French, 2002). The popularity of the Jensen Index compared to the other indexes-Sharpe, and Treynor lies in the fact that the Jensen Index permits researchers to ascertain whether or not abnormal portfolio returns are statistically significant when compared to the overall market (Asbere, Kleiman, \& McGowan, 1991). For these reasons, the Jensen Index was utilized to measure performance in this research. Below is the mathematical representation of these three performance measure indices.

Sharpe Index 
The Sharpe Index (1966) is used to measure investment performance using total risk. The equation is as follows:

$$
S I_{j}=\frac{R_{j}-R_{f}}{\sigma_{j}}
$$

Where:

$$
\begin{aligned}
& S I_{j}=\text { the Sharpe Index for company } j \\
& R_{j}=\text { the nominal return for company } j \\
& R_{f}=\text { the risk free rate of return } \\
& \sigma_{j}=\text { the standard deviation of returns for company } j
\end{aligned}
$$

Thus, the Sharpe Index measures reward -to-variability. The numerator in the equation measures the company's risk premium while the denominator measures the total variability of the returns. Therefore, the higher the index, the greater the risk-adjusted return. In addition, a company's portfolio will perform better than the market portfolio when its Sharpe Index is greater than the market's ratio $\left.\left(R_{m}-R f\right) / \sigma_{m}\right]$

\section{Treynor Index}

The Treynor (1965) Index measures investment performance using systematic risk. The equation is as follows:

$$
T I_{j}=\frac{R_{j}-R_{f}}{\beta_{j}}
$$

Where: 


$$
\begin{aligned}
& T I_{j}=\text { the Treynor index for company } j \\
& B_{j}=\text { the measure of systematic risk for company } j
\end{aligned}
$$

Since the market beta is one, the market's $T I$ is $R_{m}-R_{f}$. It follows therefore that a company will perform better than the market if its $T I$ is larger than $R_{m}-R_{f}$.

\section{Jensen Index}

The Jensen (1968) Index is an ex-post alpha measure (JI) used to determine the size of abnormal returns achieved by a company or its portfolio. The equation for the Jensen Index is as follows:

The Jensen Index can be seen as follows:

$$
\left(R_{i, t}-R_{f, t}\right)=\alpha_{t}+\beta_{t} *\left(R_{m, t}-R_{f, t}\right)+s_{i, t}
$$

Where $R_{t, t}$ is the return on portfolio i at time $\mathrm{t} ; R_{f, t}$ is the return on the risk-free asset at time $\mathrm{t} ; R_{m, t}$ is the market return at time $\mathrm{t}$; $\boldsymbol{\alpha}_{i}$ is the Jensen Index measure of performance on portfolio $\mathrm{i} ; \beta_{i}$ is the systematic risk for portfolio I; and $\varepsilon_{i, t}$ is the random error with expected value equal to zero (i.e. $\mathrm{E}\left(\varepsilon_{i, t}\right)=0$ ).

In terms of benchmark measures, the Standard \& Poor's Compoite index has been used extensively as a general benchmark for the stock market as a whole as well as a benchmark for evaluating the overall performance of investments. However, the major criticism that the S\&P 500 has been subjected to as benchmark has been the fact that it comprises a sample of 500 major stocks traded on the US stock market. Hence, the major criticism is that the 500 companies that comprise the S\&P 500 some of the largest in the 
United States, and hence, it may not be accurate in comparing smaller companies to a composite of these companies. On the other hand, if the companies that are being compared to the S\&P benchmark are similar to the benchmark, then it is appropriate to use the S\&P 500 as a benchmark (Block \& French, 2002).

Other studies on REIT performance have focused not on the sector's performance relative to market benchmarks, such as the S\&P 500 or the NYSE, but instead have focused on the non financial market information to evaluate performance of REIT owned properties compared. For example, Brady \& Conlin, (2004), compared the performance of REIT owned (hotel) properties to non-REIT properties. In their study, Brady \& Conlin, (2002), examined the performance of by using property level information of hotels in Texas to ascertain if REITs owned hotel properties performed better than nonREITs owned properties. The study found that on average, REIT owned hotels performed better than non-REIT owned properties based on the four predetermined operational criteria. For example, REIT ownership was found to increase REVPAR by nine percentage points, and the finding was found to be statistically significant. The authors concluded that the superior performance of REIT own hotels was not attributed to the market power of REITs, but instead was based more on the types of amenities and level of service offered by the REIT owned hotels.

Several researchers have focused on the use of benchmarks used to evaluate performance. For example, Han \& Liang, (1995) found that the use of the S\&P 500 index leads to results that overstate performance of REIT portfolios, relative to the stock market portfolio. Similar findings were reported by (Liang, McIntosh, \& Ziering, 1999). 
In addition, multiple benchmarks should be used to ascertain the relative performance of investments. These include the CRSP equally weighted and the CRSP value weighted indices. These portfolios are deemed to resemble the US stock market portfolio closest and are often used as proxies for the market (Han \& Liang, 1995). The value weighted CRSP portfolio represents small stocks that trade on the AMEX, NASDAQ and NYSE while the CRSP equally weighted index represents the large companies that trade on these same markets. This is important since several lodging REITs have small .market capitalizations (\$20-\$100 million), and would therefore not be included in benchmarks such as the S\&P 500 index. For these reasons, several benchmarks were utilized to represent market portfolios in this research to overcome the perceived and suggested weaknesses highlighted

\section{THE FUTURE OF REITs}

As discussed in chapter one, the history of REITs as a whole has been marked by persistence and resilience. The general consensus as it pertains to its future as an investment vehicle however is that REITs will continue to grow and continue to play a great role as investment vehicles (Chan et al., 2003;Mullaney, 1998;NAREIT, 2006). However, to remain competitive, REITs must continue to evolve and adjust to the changing marketplace. Hence, REITs must constantly strive to remain competitive and continue to offer investors value.

If the historical performance of REITs is an indication and harbinger of its future 
performance, then it safe to assume that in the future, REITs will continue to display resilience and evolve and adjust to changing conditions in the marketplace. Although REIT stock performance over the past four decades has not exceeded those of other stocks in the marketplace, there continues to be a strong demand for this investment vehicle. Hence, it follows therefore that as long as demand is strong, REITs as investment vehicles will continue to survive. In addition, the transformation and maturity of the of the REIT industry during the 1990s have enabled it to take advantage of changing market conditions which will undoubtedly propel its growth as an in vestment vehicle. Prior to the changes which occur during the 1990's REITs were criticized for their fund-like structure and resulting agency costs. Consequently, few institutional investors participated in the REIT market. However, since the changes in legislations in the 1990's, REITs have become more operational in nature and display characteristics that meet the expectations of institutional investors. In addition, the fact that REITs have become more diverse and dynamic in recent years will ensure that it will continue to be an attractive investment vehicle.

There are several factors that point to, and suggest that REITs will continue to grow and evolve as investment vehicles. First and foremost is the fact that market conditions suggest that there is potential for increased securitization and growth of the REIT industry in the United States. In fact, current estimates suggest that REITs account for only $10 \%$ of the total real estate owned by institutional investors (Chan et al., 2003). This suggests that there is potential and room for growth for this investment vehicle currently and in the future. In addition, REITs will continue to be attractive to investors 
because of their relatively high dividend payout ratios combined with zero corporate income taxes. Therefore, whenever the stock market is favorable to investors, REITs and other stocks will undoubtedly perform well. However, if the market is perceived as not performing favorably or seems to be volatile, as indicated by falling stock prices, investors might be reluctant to sell their stocks, and instead will hold them until prices rebound. However, in order for REITs to continue to grow and evolve, REIT managers must ensure that in the face of increased attention given to these REITs that they do not eventually become overpriced, especially as their yields equal or surpass those of other stocks. Thus, overall, while it is always dangerous to attempt to predict the future, there is no reason not to think that REITs will continue to flourish in the foreseeable future. 


\section{CHAPTER III}

\section{METHODOLOGY}

The intent of Chapter three is to present the methodology employed in this research. The research design followed a quantitative approach. The purpose of using a quantitative approach is to examine the performance of hotel real estate investment trusts and present the evidence as to how lodging REITs performed as investment vehicles. The results of this analysis will assist real estate investment trust investors as well as lodging asset managers in better understanding the nature and performance of their investment. The chapter comprises six distinct sections. Section one focused on the statement of problem; section two introduces the research design while section three presented the research questions. Section four addressed the data collection and data source in general, while section five focused on data analysis and presented the various research methods in terms of approaches and their applicability to the research questions. Section six focused on data collection and data source while the final section, focuses on the validity and reliability of the study.

\section{Problem Statement}

Several studies have been conducted relating to how REITs have performed as investment vehicles. For the most part, such studies have employed the 
traditional Jensen model, Capital Asset Pricing Model (CAPM), multiple index models and two-factor models. However, to date, little research has been undertaken to examine the performance of a key segment of the equity real estate market, lodging or hotel REITs. This is despite the fact that this segment represents a growing and significant asset class in the REIT industry. Lodging REITs have grown significantly in terms of numbers, from two at the start of 1993, to a total of nineteen at the end of 2005. During the same period, their capitalization grew from $\$ 100$ million (Gu \& Kim, 2003), to an estimated equity market capitalization of $\$ 17,617,000,000$ (National Association of Real Estate Investment Trusts, 2006). This growth has both increased the cash flow into the lodging industry while at the same time changed the real estate ownership structure within the lodging industry (Kim, Gu, \& Mattila, 2002). The growth of hotel REITs in terms of their absolute numbers as well as their market capitalization suggests that knowledge and understanding of the performance of this segment is important, especially for investors in making investment and diversification strategy decisions. Thus, this research is an important, necessary and meaningful task since the findings will provide information that will assist individual investors, institutional investors, asset managers and hospitality executives in effectively managing their hotel real estate portfolios and ultimately, maximize their shareholders' wealth.

\section{Research Design Overview}

This study is designed to determine whether or not lodging REITs over-perform or under-perform relevant market benchmarks. In this regard, lodging REITs were 
compared to relevant industry benchmarks such as the Standard \& Poor's 500 Market Weighted Index (S\&P500), the CRSP/NYSE/AMEX/NASDAQ (CRSP) value weighted and equally weighted indices, and the National Association of Automated Dealers Quotation System (NASDAQ) Composite Index. As discusses previously, these indices or market portfolios are commonly used as benchmarks against which to measure performance. As noted previously, generally, there are three indices that are used to measure the risk adjusted performance of portfolios. These are, the Treynor index (Treynor, 1965), the Jensen index (Jensen, 1968) and the Sharpe index (Sharpe, 1966). Of the three, the most common and widely used performance measure method for riskadjusting returns are those that are based on Jensen's alpha (Jensen, 1969), which is generally used to measure whether or not a portfolio overperforms or underperforms compared to established stockbroker benchmarks (Han \& Liang, 1995).

The study is also designed to address the issue of whether lodging REITs over perform or underperform other equity REITs. The other equity REITs include industrial REITs, Retail REITs, Residential REITs, Diversified REITs, Health Care REITs, Self Storage REITs and Specialty REITs. This classification is based on the property specialization or property sector developed by the National Association of Real Estate Investment Trusts (NAREIT). Finally, lodging REITs persistence (or consistency in performance) is also a subject of this study. In this regard, the data were split into two equal time periods and then analyzed. 


\section{RESEARCH QUESTIONS}

This research was designed to answer three research questions.

\section{Research Question One}

In one study conducted to ascertain the risk and return characteristics of different equity REITs, it was found that hotel REITs had higher returns than the benchmark, the Standard \& Poor's MidCap 400 index (Chen \& Peiser, 1999). Conversely, hotel REIT adjusted risk performance was found to be similar to the performance of the market portfolio (Kim, Mattila, \& Gu, 2002). Chen \& Peiser (1999) found that REITs underperformed stocks on a nominal return basis and performed no better than stocks on a risk-adjusted basis. Similar findings were reported by Sanders (1998), who compared the risk adjusted return performance of equity REITs against several benchmarks which included the S\&P 500 index and the Wilshire index during the 1978 to 1996 period and found that during the study period, equity REITs performed no better than the stock market indices as it pertained to their risk adjusted excess returns. Additionally, Chan et al., (2003) analyzed several studies relating to REIT performance and noted that over the long run, REIT portfolios have not outperformed the stock market. Similar findings were reported by Smith, (1980), who compared the performance of equity REITs with that of common stocks and found that during the sample period, equity REITs performed slightly better or about the same as CEM funds on a risk-adjusted basis. 
Question 1: Do lodging REITs over-perform or under-perform relevant market benchmarks?

\section{Research Question Two}

Hotel REIT returns represent the most volatile of all equity REIT sectors (Imperiale, 2002). In a study of the performance of the hotel REIT sector, compared to other equity REITs, hotel REITs were found to display inferior performance (Kim, Gu, \& Mattila, 2002).

Question 2: Do lodging REITs over-perform or under-perform other equity REITS?

\section{Research Question three}

It has been noted that the price and performance of REITs are tied to the performance of the REITs primary source of income. Since the demand for lodging is intricately tied to and is affected by fluctuations in the economy, the overall demand for lodging over the long-term is not stable. Hence the performance of lodging REITs, which are intricately tied to the demand for guest-room, may not be consistent from one period to the next. Further, Han \& Liang, (1995) found that although REIT performance was similar to the market during the period 1970-1993, their overall performance was however not stable over time (Li \& Wang, 1995). In addition, Jegadeesh, (1990) found that returns are generally not consistent from one period to another. Thus, performance of investments changes over time. 
Question 3: Is the performance of lodging REITs persistent?

\section{Data Collection and Data Source}

In order to gain an in-depth understanding of the performance of lodging real estate investment trusts, this study utilized time series data obtained from the Center for Research in Security Prices (CRSP) database. Specifically, the study analyzed the monthly REIT stock returns for the period January 1993 to December 2005.

The Center for Research in Security Prices has provided comprehensive historical stock US market data since 1962. Their data files include common stocks on the New York Stock Exchange (NYSE), the American Stock Exchange (AMEX), the Standards and Poor's 500 (S\&P 500) and the National Association of Securities Dealers Automated Quotations (NASDAQ) and CRSP value weighted and CRSP equally weighted indices. The CRSP stock files indices are provided in four frequencies: daily, monthly, quarterly, and annually. The monthly data were utilized for this study.

The sample comprised 297 equity REITs that traded on the New York Stock Exchange (NYSE), the American Stock Exchange (AMEX), the Standard and Poor's 500 (S\&P 500) and the National Association of Securities Dealers Automated Quotations (NASDAQ) during the period January1993 through December 2005. The returns were adjusted for stock splits and dividends. Initially, a total of 403 REITs were extracted from the database which included REITs that were currently being traded as well as those that had exited the market. REITs that traded for less than twelve months and those with missing or incomplete data were removed from the sample which resulted in 380 total REITs. The final count was 297 equity REITS, the rest being non-equity or classes not 
considered for this study.

The remaining equity REITs were then classified according to their investment sector (equity, mortgage, or hybrid) using constituent data obtained from the National Association of Real Estate Investment Trusts (NAREIT). They were further classified into their respective property sectors (diversified, health care, self storage, industrial, office, residential, retail, lodging, specialty, or mixed). REITs were classified according to their last trading investment and property sectors as reported by NAREIT. This classification was based on the $75 \%$ classification rule which classifies a company according to the percentage of assets invested in a specific sub-sector. According to this rule, if $75 \%$ or more of a company's assets are invested in a specific sector, the company is classified as being in that sector. This classification resulted in a total of 299 equity REITs, of which 28 were classified as diversified, 16 were health care, 26 were industrial, 28 were lodging, 5 were classified as mixed, 36 were classified as office, 57 were residential, 70 were retail, 22 were self storage, and 11 were specialty. It should be noted that during the study period, two lodging REITs were classified as hybrids and thus were excluded from the study, leaving a total of 297 REITs, of which 26 were lodging. Table 4 presents a summary of the twenty-six REITs, their trading ticker and their last reported market capitalization.

TABLE IV 


\section{LODGING REITS AND THEIR LAST REPORTED MARKET}

\section{CAPITALIZATION}

\begin{tabular}{|c|c|c|}
\hline REIT Name & Ticker & $\begin{array}{l}\text { Last reported Market Capitalization } \\
\qquad \$ \mathrm{~m}\end{array}$ \\
\hline Ashford Hospitality Trust & $\mathrm{AHT}$ & 459,787 \\
\hline Banyan Hotel Investment Fund & VHT & 3,549 \\
\hline Boykin Lodging Company & BOY & 214,999 \\
\hline Host Funding & HFD & 512 \\
\hline Eagle Hospitality Properties Corporation & EHP & 132,487 \\
\hline Equity Inns, Inc. & ENN & 731,714 \\
\hline FelCor Lodging Trust Inc & $\mathrm{FCH}$ & $1,035,715$ \\
\hline Hersha Hospitality Trust & HT & 12,250 \\
\hline Highland Hospitality Corp. & $\mathrm{HIH}$ & 570,081 \\
\hline Host Marriott Corp New & HMT & $6,698,048$ \\
\hline Starwood Hotel \& Resorts & HOT & 14,000 \\
\hline Jameson Inn Inc & JAMS & 28,031 \\
\hline RFS Hotel Investors Inc & RFS & 363,686 \\
\hline Innkeepers USA Trust & KPA & 687 \\
\hline La Quinta Corporation & LQI & $2,258,468$ \\
\hline LaSalle Hotel Properties & LHO & $1,197,219$ \\
\hline MeriStar Hospitality Corp. & MHX & 822,434 \\
\hline Innsuites Hospitality Trust & IHT & $11,796.3$ \\
\hline Strategic Hotel Capital & SLH & 903,009 \\
\hline MHI Hospitality Corporation & $\mathrm{MDH}$ & 59,680 \\
\hline Strategic Hotel Capital, Inc. & SLH & 1,618 \\
\hline Sunstone Hotel Investors Inc.N & SHO & $1,272,490$ \\
\hline Sunstone Hotel Investors INC & SSI & 362,820 \\
\hline Wyndham Intl Inc. & WBR & 873,918 \\
\hline Supertel Hospitality Inc. & SPPR & 57,666 \\
\hline Winston Hotels & WXH & 262,439 \\
\hline
\end{tabular}

Source: National Association of Real Estate Investment trusts, December 2005

To estimate the overall return of each REIT sector the monthly return of each sector was first derived as the equally weighted price change plus equally weighted dividend yield of the REIT in the sector.

Since the study is designed to determine whether or not lodging REITs over- 
perform or under-perform relevant benchmarks, the appropriate benchmarks had to be chosen. The benchmarks selected for this study were the Standard \& Poor's 500 Market Weighted Index (S\&P500), the CRSP equally weighted index, the CRSP value weighted Index, and the National Association of Automated Dealers Quotation System (NASDAQ) Composite Index. These four indices were chosen since they are commonly used as benchmarks against which to measure performance (Kim et al., 2002; Oppenheimer \& Grissom, 1998; Han \& Liang, 1995). The benchmark data were also obtained from the CRSP database. It was also decided to use the monthly return on the three-month US Treasury Bill (90 days Treasury) as a proxy for the risk-free rate for this study. Several other studies (Kim et al., 2002;Oppenheimer \& Grissom, 1998; Han \& Liang, 1995) relating to the performance of REITs have used the three month US Treasury Bill as a proxy for the risk free rate. The risk free data were obtained from the United States Federal Reserve website ( http://www.federalreserve.gov/).

\section{Data Analysis}

There are three common indices used for measuring risk-adjusted performance of stock portfolios: they are the Sharp Index (Sharp, 1966), the Treynor Index (Treynor, 1965), and the Jensen Index (Jensen, 1968). All three of these indices generally assume that the Capital Asset Pricing Model (CAPM) theory holds. This theory generally states that a portfolio's expected price is comprised of the risk-free rate plus the systematic risk multiplied by the market risk premium, which is the expected market return less the risk free rate. The systematic risk is labeled Beta and is the covariance of the market return 
and the individual portfolio's return divided by the variance of the market return. The Sharp Index and the Treynor Index are both based on the ratio of return to risk. The Jensen Index however attempts to measure the relative performance based on the Security Market Line (SML). Of the three, the most commonly and widely used risk adjusted performance measure are those based on Jensen's alpha, which is generally used to measure whether or not a portfolio over-performs or under-performs compared to an established benchmark. Mathematically, the Jensen Index can be seen as:

$$
\left(R_{i, t}-R_{f, t}\right)=\alpha_{i}+\beta_{i} *\left(R_{m, t}-R_{f, t}\right)+a_{i, t}
$$

Where $R_{t, t}$ is the return on portfolio $i$ at time $t ; R_{f, t}$ is the return on the risk-free asset at time $t ; \mathbb{R}_{m, t}$ is the market return at time $t ; \alpha_{i}$ is the Jensen Index measure of performance on portfolio $i$; $\beta_{i}$ is the systematic risk for portfolio $i$; and $\varepsilon_{i, t}$ is the random error with expected value equal to zero (i.e. $\mathrm{E}\left(\varepsilon_{i, t}\right)=0$ ).

The risk-free rate is essentially the return that an investor would expect to receive assuming that there was no risk involved in receiving it. In other words, the return was not subject to default risk, yield curve risk, inflation risk, along with various other risks affecting securities. As previously noted, for this study, it was decided to use the monthly return on the three-month US Treasury Bill as a proxy for the risk-free rate.

The $\alpha_{i}$ and $\beta_{i}$ in the Jensen Index were estimated using the Least-Squares Regression procedure. This statistical method plots a line through the data that minimizes the sum of the squared errors. For the regression, the market excess return was the independent variable and the REIT portfolio less the risk-free rate was the dependent variable. This means that $\alpha_{i}$ was the estimated excess return (or loss) on the 
REIT and $\beta_{i}$ was the estimate for the systematic risk on the REIT. To determine whether or not a given REIT portfolio over-performed or under-performed as compared with an established benchmark (or market portfolio), we simply need to determine if $\alpha_{i}$ is statistically different from zero. To determine if the REIT portfolio contributed more or less risk than the market portfolio we need to determine if $\beta_{l}$ is statistically different from 1 .

In order to perform the detailed calculations used in the study several software programs were utilized. The raw data that were initially extracted from the Center for Research in Security Prices (CRSP) database were downloaded into Microsoft Excel. The data were then sorted through using the filter function and then categorized with the use of Excel pivot tables. Individual REITs were then equally weighted to represent a composite for each property sector. All statistics for the first and second research questions were performed using Microsoft Excel 2007, with the exception of the Dubin Watson test statistics which were calculated using SPSS Version 14. The model used to answer research question three was also performed using SPSS Version 14, as were the model diagnostic tests that were performed.

\section{Validity and Reliability}

There are two very useful concepts from statistical measurement theory that are relevant here: validity and reliability -which basically correspond to consistency and accuracy, (Miller \& Miller, 1986; Kirk, 1986). In this regard, content validity is concerned with sample-population representation. That is, the knowledge and skills 
covered by the test items should be representative to the larger domain of knowledge and skills, (Messick, 1998). Content validity was established by examining the "face validity" of each variable and reviewing the theoretical models and methods used to develop the variables.

In this regard, content validity was established by the researcher who reviewed the theoretical models and methods used to explore the performance of REITs. This review included an examination of a series of literature including the history and evolution of REITs, the appeal of REITs as investment vehicles, and REITs performance as investment vehicles. A review of the common measures of-the Jensen Index, Sharpe Index and the Treynor index was also conducted. Based on this review and analysis, it was determined that the Jensen index is appropriate for this study.

Content validity was established since the data used for this research were obtained from the Center for Research in Security Prices (CRSP) database. The Center for Research in Security Prices (CRSP) has been the leading provider of historical research-quality stock market data to nearly 500 institutions. CRSP maintains some of the largest, and most comprehensive proprietary historical databases in the industry. Academic researchers and investment professionals rely on CRSP for accurate, survivorbias-free information which provides a foundation for their research and analyses. The statistical tests performed in this study have proven reliability and robustness. For example, tests were perform to detect serial correlations.

\section{Summary}

In summary, the purpose of chapter three was to present the methods that were 
used in this research study. Hence, the problem statement, research design, and research questions were presented. The data collection, data source and data analysis methods were also presented. Finally, validity and reliability of the study were emphasized. 


\section{CHAPTER IV}

\section{FINDINGS}

This chapter presents the empirical findings for this study and provides an analysis of the results. The chapter focuses on providing the analysis and results for the three research questions that were developed. The analysis and results focused on each specific research question.

\section{ANALYSIS AND RESULTS \\ Research Question One}

To answer this question, a series of non-risk adjusted descriptive statistics were performed. Table $\mathrm{V}$ provides a summary of those results. Here we see that lodging REITs have an average monthly return during the period of $0.89 \%$, which is only slightly higher than the $0.81 \%$ return that the equity REIT market had overall. However, its standard deviation at $6.38 \%$ is twice that of the equity REIT market portfolio at $3.12 \%$, which would indicate that the lodging REITs are riskier or more volatile than other equity REITS overall. As expected the 90-day treasuries, the proxy for the risk-free rate, had by far the lowest standard deviation at $0.14 \%$, but had the lowest average monthly return as 
well at $0.32 \%$. This indicated that they were less risky, but have consistent, albeit lower returns.

TABLE V

DESCRIPTIVE STATISTICS OF MONTHLY

RATE OF RETURN JANUARY 1993 - DECEMBER 2005

\begin{tabular}{|l|l|l|r|r|}
\hline \multicolumn{1}{|c|}{ Sector } & Mean & \multicolumn{1}{c|}{ STD } & Minimum & Maximum \\
\hline Lodging REIT & $0.89 \%$ & $6.38 \%$ & $-26.41 \%$ & $26.27 \%$ \\
\hline Diversified REIT & $0.85 \%$ & $3.33 \%$ & $-10.81 \%$ & $14.03 \%$ \\
\hline Health Care REIT & $0.63 \%$ & $4.60 \%$ & $-17.14 \%$ & $16.16 \%$ \\
\hline Industrial REIT & $1.28 \%$ & $4.53 \%$ & $-15.08 \%$ & $20.39 \%$ \\
\hline Mixed REIT & $0.91 \%$ & $5.37 \%$ & $-20.06 \%$ & $18.42 \%$ \\
\hline Office REIT & $1.08 \%$ & $4.18 \%$ & $-14.22 \%$ & $17.28 \%$ \\
\hline Residential REIT & $0.93 \%$ & $3.82 \%$ & $-7.06 \%$ & $31.36 \%$ \\
\hline Retail REIT & $0.59 \%$ & $3.38 \%$ & $-15.09 \%$ & $9.31 \%$ \\
\hline Self Storage REIT & $1.00 \%$ & $3.94 \%$ & $-16.60 \%$ & $12.10 \%$ \\
\hline Specialty REIT & $0.10 \%$ & $4.94 \%$ & $-14.26 \%$ & $15.75 \%$ \\
\hline Equity REIT Portfolio & $0.81 \%$ & $3.12 \%$ & $-12.39 \%$ & $9.22 \%$ \\
\hline S\&P 500 Index & $0.76 \%$ & $4.11 \%$ & $-14.58 \%$ & $9.67 \%$ \\
\hline $\begin{array}{l}\text { CRSP Equally Weighted } \\
\text { Index }\end{array}$ & $1.32 \%$ & $5.33 \%$ & $-19.64 \%$ & $22.50 \%$ \\
\hline CRSP Value Weighted & $0.93 \%$ & $4.25 \%$ & $-15.77 \%$ & $8.39 \%$ \\
\hline NASDAQ & $1.05 \%$ & $7.51 \%$ & $-22.90 \%$ & $21.98 \%$ \\
\hline 90-day Treasuries & $0.32 \%$ & $0.14 \%$ & $0.07 \%$ & $0.53 \%$ \\
\hline *REIT portfolio contains all 10 sectors consisting of 297 REITs used in this study \\
\end{tabular}

However, while the non risk-adjusted returns provide interesting information regarding the risk / return relationship, risks-adjusted analysis provides vastly greater insight into the overall structure of the various "real" returns. Table VI below shows the Jensen Index for each REIT sector which was estimated using least squares regression.

As stated previously, the $\alpha$ 's and $\beta$ 's were estimated using the least squares linear regression method, and the market portfolio was first estimated by the S\&P 500 Index. 
In order to determine if an individual sector REIT, or the REITs sector as a whole, had an excess return (either positive or negative) the $\alpha$ 's were tested to determine if their values were statistically different from zero.

\section{TABLE VI}

\section{PERFORMANCE OF REIT SECTOR RELATIVE TO THE S\&P500 USING JENSEN}

\section{INDEX}

JANUARY 1993-DECEMBER 2005

$$
(R i-R f)=\alpha+\beta *(R m-R f)+\varepsilon
$$

\begin{tabular}{|c|c|c|c|c|c|c|c|}
\hline $\begin{array}{c}\text { Dependent } \\
\text { Variable }\end{array}$ & $A($ coeff $)$ & A (t-stat) & B (coeff) & $\beta$ (t-stat) & $\mathbf{R}^{2}$ & F- Value & $\begin{array}{c}\text { Dubin } \\
\text { Watson }\end{array}$ \\
\hline Lodging REIT & 0.0033 & 0.679126 & 0.5414 & $-3.8938 * * *$ & 0.1207 & 21.1309 & 1.923 \\
\hline Diversified REIT & 0.0045 & $1.705761 *$ & 0.1953 & $\overline{1}-6429 * * *$ & 0.0576 & 9.4195 & 1.980 \\
\hline $\begin{array}{l}\text { Health Care } \\
\text { REIT }\end{array}$ & 0.0021 & 0.574815 & 0.2318 & $-8.6499 * * *$ & 0.0423 & 6.8098 & 1.985 \\
\hline Industrial REIT & 0.0086 & $2.401099 * *$ & 0.2137 & $-8.9902 * * *$ & 0.0373 & 5.9724 & 2.258 \\
\hline Mixed REIT & 0.0050 & 1.160329 & 0.2010 & $-7.6691 * * *$ & 0.0236 & 3.7209 & 2.461 \\
\hline Office REIT & 0.0065 & $1.988662 * *$ & 0.2454 & $-9.4522 * * *$ & 0.0578 & 9.4452 & 2.236 \\
\hline Residential REIT & 0.0052 & $1.723269 *$ & 0.2045 & $10.8387 * * *$ & 0.0480 & 7.7589 & 2.193 \\
\hline Retail REIT & 0.0018 & 0.668687 & 0.2051 & $12.2256 * * *$ & 0.0607 & 9.9519 & 2.154 \\
\hline $\begin{array}{l}\text { Self Storage } \\
\text { REIT }\end{array}$ & 0.0060 & $1.912137 * *$ & 0.1891 & $\begin{array}{l} \\
10.6449 * * *\end{array}$ & 0.0385 & 6.1646 & 2.155 \\
\hline Specialty REIT & -0.0037 & -0.97385 & 0.3430 & $-7.0465 * * *$ & 0.0808 & 13.5368 & 2.459 \\
\hline REIT Portfolio & 0.0038 & 1.590234 & 0.2503 & $\begin{array}{l} \\
12.8436 * * *\end{array}$ & 0.1067 & 18.3938 & 2.137 \\
\hline
\end{tabular}

(1) $*, * *, * * *$ indicates significant at the $10 \%, 5 \%$, and $1 \%$ levels, respectively

(2) REIT Portfolio contains all ten sectors consisting of the 297 REITS included in the study.

(3) F-Value's are all significant at the 0.001 level.

A statistically significant value different from zero implies that the particular

REIT sector either over-performed or under-performed the particular market portfolio 
used (in this case the S\&P 500). An $\alpha$ that was statistically significant and positive implied that the REIT over-performed the market portfolio and an $\alpha$ statistically significant and negative implied that the REIT under-performed the market portfolio.

Even though all of the REIT sectors have $\alpha$ coefficients greater than zero (except Specialty REITs which were not statistically different than zero when testing) which may initially imply that they over-performed the market portfolio, upon closer examination we see that only Industrial, Office and Self Storage REITs have $\alpha$ 's that are significant at the at the 0.05 level. This means that Lodging, Diversified, Health Care, Mixed, Residential, Retail, and Specialty REITs all performed similar to the market portfolio on a risk-adjusted basis.

The $\beta$ 's tell us whether the particular REIT sector is riskier or less risky than the market portfolio. The $\beta$ 's were tested to see if they were statistically significantly different than a value of one. A $\beta$ of one would imply that the particular REIT sector had a risk level approximately the same as the market portfolio; a $\beta$ greater than one would imply that the REIT sector was riskier than the market portfolio; and a $\beta$ less than one implies a REIT sector that is less risky than the market portfolio. Table VI shows that all of the REIT sectors have $\beta$ 's that are significant at least the 0.01 level. This would imply that all of the REIT sectors are statistically less risky than the market portfolio. While there was no evidence to suggest that the lodging REIT sector over-performed the market portfolio, there was evidence that other sectors did so. Both Diversified and Residential were statistically significant at the 0.01 levels and Industrial, Office and Self Storage at the 0.05 level. Based on the results, there is no reason to believe that lodging REITs 
performed any better on a risk adjusted basis than did the market portfolio.

Before moving deeper into the results it is necessary to first look at some basic model diagnostics. The first examination is for serial correlation which might be an issue given the time dependent nature of the data. In this regard, the Dubin Watson test statistic was conducted to look for Lag 1 autocorrelation. Based on the results of this test we can see that this was not be a problem for data. Table VI above shows the Dubin Watson test statics for each sector which were calculated using the SPSS statistical software.

The next test was to ascertain if the independent variable were symmetric and approximately normally distributed. The independent variable for this test was the S\&P 500 Index less the risk free rate of return, and the dependent variable in question is the lodging REIT sector less the risk free rate. The S\&P 500 Index had only minor deviations from normality when tested. Below are a scatter plot (figure 1) of both the independent and dependent variables together and a frequency histogram (figure 2) of the independent variable. These diagrams show that the data are evenly distributed and symmetrical.

The market portfolio or benchmark in Table VI was estimated using the S\&P 500. It was also of interest to see how the results would have changed if a different Index was used as a proxy to the market portfolio instead. Hence, it was decided to use the CRSP equally Weighted Index, the CRSP Value Weighted Index, and the NASDAQ Index as market portfolios in the model to represent benchmarks against which performance could be measured. Below are the results of these analyses. Table VII presents the results 
using the CRSP equally weighted index, Table VIII presents the CRSP value weighted index, and Table IX presents the NASDAQ index as market portfolios.

\section{FIGURE I}

SCATTER PLOT OF S\&P 500 INDEX LESS RISK FREE RATE VERSUS LODGING REIT SECTOR RETURN LESS RISK FREE RATE

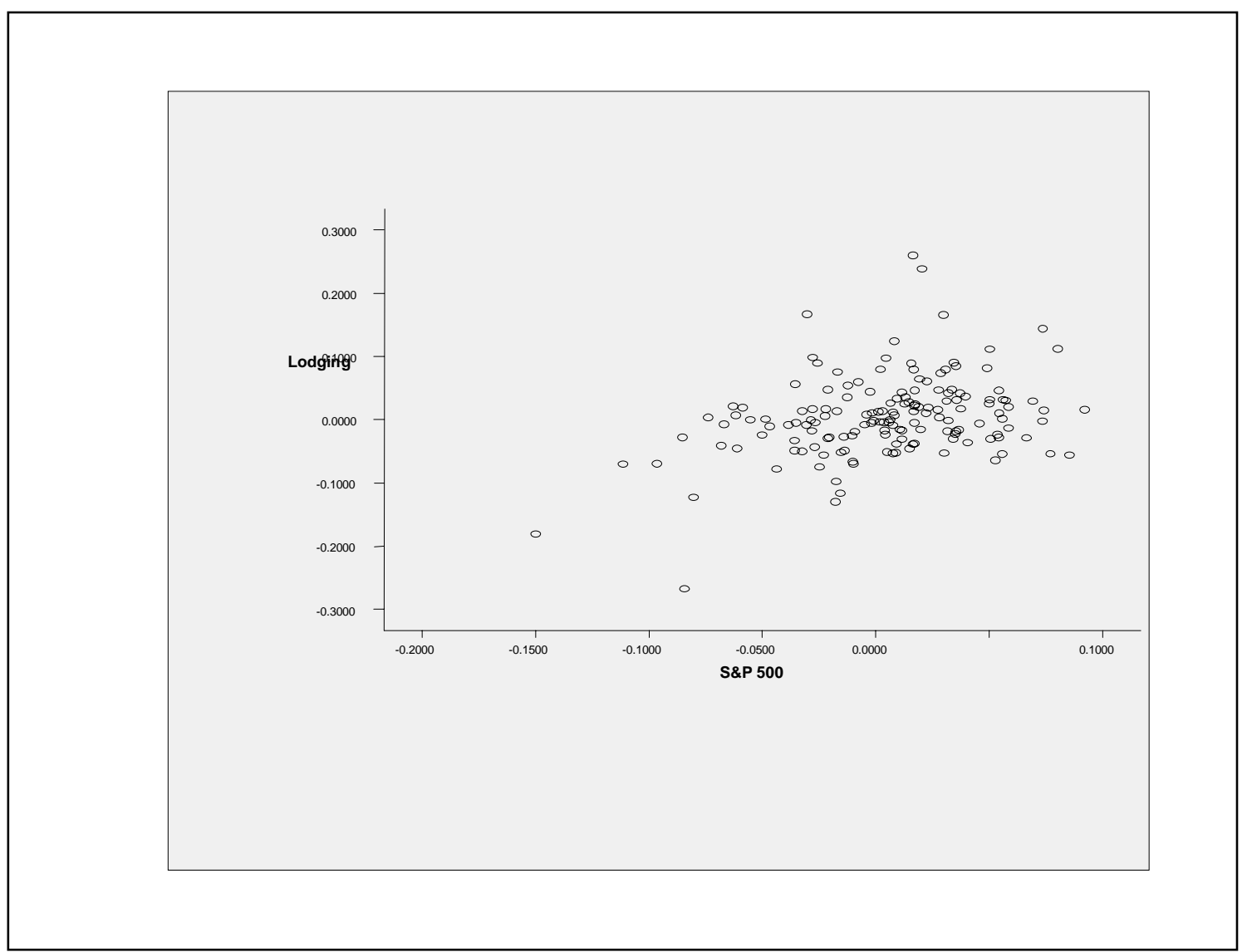


FIGURE II

FREQUENCY HISTOGRAM OF S\&P 500 INDEX LESS RISK FREE RATE

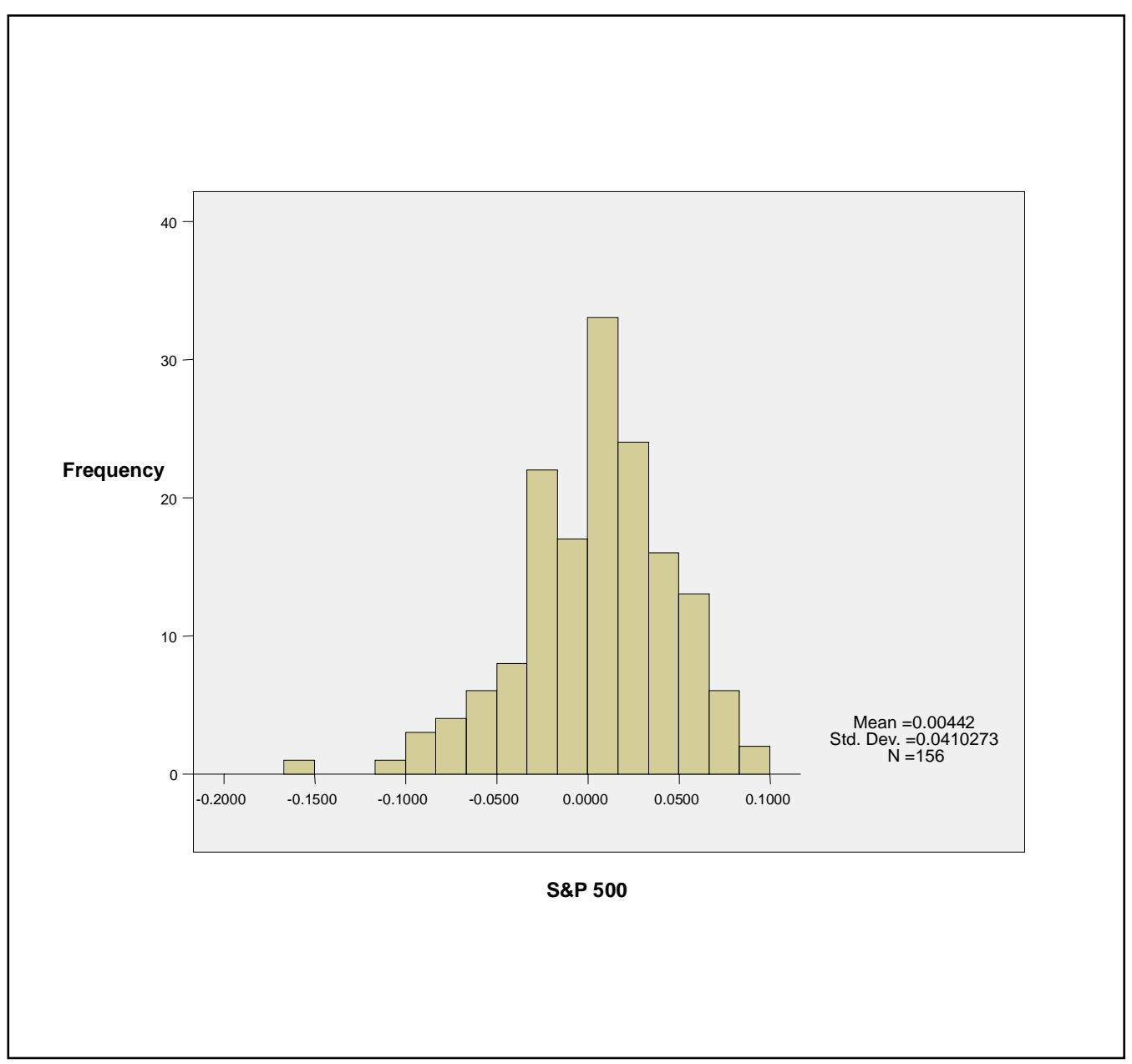

TABLE VII

PERFORMANCE OF REIT SECTOR RELATIVE TO THE CRSP EQUALLY WEIGHTED USING JENSEN INDEX JANUARY 1993 - DECEMBER 2005

$$
R i-R f)=\alpha+\beta *(R m-R f)+\varepsilon
$$




\begin{tabular}{|c|c|c|c|c|c|c|c|}
\hline $\begin{array}{c}\text { Dependent } \\
\text { Variable }\end{array}$ & $\alpha$ (coeff) & $\alpha(t-s t a t)$ & B (coeff) & $\beta$ (t-stat) & $\mathbf{R}^{2}$ & F- Value & Dubin Watson \\
\hline $\begin{array}{l}\text { Lodging } \\
\text { REIT }\end{array}$ & -0.0004 & -0.0902 & 0.6108 & $-4.6950 * * *$ & 0.2607 & 54.3003 & 1.929 \\
\hline $\begin{array}{l}\text { Diversified } \\
\text { REIT }\end{array}$ & 0.0030 & 1.1930 & 0.2314 & $-16.4434 * * *$ & 0.1373 & 24.5104 & 1.990 \\
\hline $\begin{array}{l}\text { Health Care } \\
\text { REIT }\end{array}$ & 0.0003 & 0.0784 & 0.2854 & $-10.8674 * * *$ & 0.1090 & 18.8407 & 1.991 \\
\hline $\begin{array}{l}\text { Industrial } \\
\text { REIT }\end{array}$ & 0.0072 & $2.0189 * *$ & 0.2412 & $-11.5674 * * *$ & 0.0807 & 13.5136 & 2.289 \\
\hline Mixed REIT & 0.0030 & 0.7106 & 0.2884 & $-9.1788 * * *$ & 0.0825 & 13.8436 & 2.515 \\
\hline Office REIT & 0.0048 & 1.4945 & 0.2864 & $-12.1435^{* * * *}$ & 0.1337 & 23.7639 & 2.300 \\
\hline $\begin{array}{l}\text { Residential } \\
\text { REIT }\end{array}$ & 0.0042 & 1.3792 & 0.1961 & $-14.4750 * * *$ & 0.0749 & 12.4724 & 2.231 \\
\hline Retail REIT & -0.0000 & -0.0136 & 0.2738 & $-15.6080^{* * *}$ & 0.1836 & 34.6343 & 2.191 \\
\hline $\begin{array}{l}\text { Self Storage } \\
\text { REIT }\end{array}$ & 0.0046 & 1.4804 & 0.2283 & $-13.6052 * * *$ & 0.0952 & 16.2077 & 2.202 \\
\hline $\begin{array}{l}\text { Specialty } \\
\text { REIT }\end{array}$ & -0.0064 & $-1.7684 * * *$ & 0.4180 & $-8.7376^{* * *}$ & 0.2036 & 39.3752 & 2.493 \\
\hline $\begin{array}{l}\text { REIT } \\
\text { Portfolio }\end{array}$ & 0.0020 & 0.8942 & 0.2945 & $-17.1930 * * *$ & 0.2507 & 51.5262 & 2.197 \\
\hline
\end{tabular}

(1) $*, * *, * * *$ indicates significant at the $10 \%, 5 \%$, and $1 \%$ levels, respectively

(2) REIT Portfolio contains all ten sectors consisting of the 297 REITS included in the study.

(3) F-Value's are all significant at the 0.001 level.

TABLE VIII

PERFORMANCE OF REIT SECTOR RELATIVE TO THE CRSP VALUE

WEIGHTED USING JENSEN INDEX JANUARY 1993 - DECEMBER 2005

$$
(R i-R f)=\alpha+\beta *(R m-R f)+\varepsilon
$$




\begin{tabular}{|l|r|c|r|l|c|c|l|}
\hline \multicolumn{1}{|c|}{$\begin{array}{c}\text { Dependent } \\
\text { Variable }\end{array}$} & $\boldsymbol{\alpha}$ (coeff) & $\boldsymbol{\alpha}$ (t-stat) & $\mathbf{B}$ (coeff) & $\mathbf{B}$ (t-stat) & $\mathbf{R}^{\mathbf{2}}$ & F- Value & $\begin{array}{c}\text { Dubin } \\
\text { Watson }\end{array}$ \\
\hline Lodging REIT & 0.0022 & 0.4664 & 0.5665 & $-3.8524^{* * *}$ & 0.1413 & 25.3395 & 1.916 \\
\hline Diversified REIT & 0.0039 & 1.5168 & 0.2307 & $-12.6937 * * *$ & 0.0860 & 14.4879 & 1.991 \\
\hline $\begin{array}{l}\text { Health Care } \\
\text { REIT }\end{array}$ & 0.0017 & 0.4666 & 0.2330 & $-8.9475^{* * *}$ & 0.0458 & 7.3900 & 1.982 \\
\hline Industrial REIT & 0.0082 & $2.2739 * *$ & 0.2317 & $-9.1310^{* * *}$ & 0.0469 & 7.5842 & 2.261 \\
\hline Mixed REIT & 0.0043 & 1.0027 & 0.2614 & $-7.4049^{* * *}$ & 0.0427 & 6.8653 & 2.467 \\
\hline Office REIT & 0.0059 & $1.8075^{*}$ & 0.2859 & $-9.3813^{* * *}$ & 0.0839 & 14.1129 & 2.248 \\
\hline Residential REIT & 0.0048 & 1.5869 & 0.2173 & $-11.0876^{* * *}$ & 0.0579 & 9.4706 & 2.190 \\
\hline Retail REIT & 0.0013 & 0.4863 & 0.2311 & $-12.3743^{* * *}$ & 0.0824 & 13.8374 & 2.159 \\
\hline $\begin{array}{l}\text { Self Storage } \\
\text { REIT }\end{array}$ & 0.0054 & $1.7474 *$ & 0.2290 & $-10.5888^{* * *}$ & 0.0604 & 9.8950 & 2.167 \\
\hline Specialty REIT & -0.0047 & -1.2457 & 0.4070 & $-6.7291^{* * *}$ & 0.1217 & 21.3356 & 2.454 \\
\hline REIT Portfolio & 0.0032 & 1.3711 & 0.2764 & $-13.0607 * * *$ & 0.1391 & 24.8920 & 2.142 \\
\hline
\end{tabular}

(1) $*, * *, * * *$ indicates significant at the $10 \%, 5 \%$, and $1 \%$ levels, respectively

(2) REIT Portfolio contains all ten sectors consisting of the 297 REITS included in the study.

(3) F-Value's are all significant at the 0.001 level.

TABLE IX

PERFORMANCE OF REIT SECTOR RELATIVE TO THE NASDAQ USING JENSEN INDEX JANUARY 1993 - DECEMBER 2005

$(R i-R f)=\alpha+\beta *(R m-R f)+\varepsilon$ 


\begin{tabular}{|c|c|c|c|c|c|c|c|}
\hline $\begin{array}{c}\text { Dependent } \\
\text { Variable }\end{array}$ & $\alpha($ coeff $)$ & $\alpha(t-s t a t)$ & $\beta$ (coeff) & $\beta$ (t-stat) & $\mathbf{R}^{2}$ & F- Value & $\begin{array}{c}\text { Dubin } \\
\text { Watson }\end{array}$ \\
\hline Lodging REIT & 0.0039 & 0.7831 & 0.2512 & $-11.4168^{* * * *}$ & 0.0870 & 14.6747 & 1.816 \\
\hline $\begin{array}{l}\text { Diversified } \\
\text { REIT }\end{array}$ & 0.0047 & $1.7660^{*}$ & 0.0935 & $-25.8781 * * *$ & 0.0443 & 7.1328 & 1.894 \\
\hline $\begin{array}{l}\text { Health Care } \\
\text { REIT }\end{array}$ & 0.0027 & 0.7291 & 0.0576 & $-19.0850 * * *$ & 0.0088 & 1.3598 & 1.963 \\
\hline Industrial REIT & 0.0090 & $2.4708 * *$ & 0.0864 & $-18.9491 * * *$ & 0.0204 & 3.2115 & 2.240 \\
\hline Mixed REIT & 0.0049 & 1.1578 & 0.1277 & $-15.3864 * * *$ & 0.0319 & 5.0693 & 2.438 \\
\hline Office REIT & 0.0069 & $2.0694 * *$ & 0.1021 & $-20.3200 * * *$ & 0.0335 & 5.3356 & 2.180 \\
\hline $\begin{array}{l}\text { Residential } \\
\text { REIT }\end{array}$ & 0.0057 & $1.8529 *$ & 0.0574 & $-23.0759 * * *$ & 0.0126 & 1.9724 & 2.156 \\
\hline Retail REIT & 0.0021 & 0.7715 & 0.0833 & $-25.4333^{* * * *}$ & 0.0336 & 5.3463 & 2.119 \\
\hline $\begin{array}{l}\text { Self Storage } \\
\text { REIT }\end{array}$ & 0.0061 & $1.9571^{*}$ & 0.0939 & $-21.6908^{* * *}$ & 0.0318 & 5.0502 & 2.090 \\
\hline Specialty REIT & -0.0039 & -1.0543 & 0.2364 & $-15.3917 * * *$ & 0.1285 & 22.6986 & 2.359 \\
\hline REIT Portfolio & 0.0042 & $1.6948^{*}$ & 0.1050 & $-27.3937 * * *$ & 0.0629 & 10.3316 & 2.058 \\
\hline
\end{tabular}

(1) $*, * *, * * *$ indicates significant at the $10 \%, 5 \%$, and $1 \%$ levels, respectively

(2) REIT Portfolio contains all ten sectors consisting of the 297 REITS included in the study.

(3) F-Value's are all significant at the 0.001 level.

It can be easily seen that the $\beta$ 's are significantly less than one using the three additional estimates for the market portfolio. In addition, the Industrial REIT sector consistently appeared to over-perform the market portfolio using all four different estimates. The Office REIT sector statistically over-performed the S\&P 500, CRSP 
Value Weighted, CRSP equally weighted and NASDAQ proxies of the market portfolio. In summary, there is no reason to believe that the lodging REIT sector over-performed the market portfolio. However, the Industrial REIT sector does appear to do just that, as it over-performed using all four of the market portfolio estimates. In essence, lodging REITs don't do better or worse statistically speaking than the market portfolios.

Industrial however is a different story, they appear to over-perform the market portfolios.

\section{Research Question Two}

To answer research question two, all 297 individual REITS were analyzed using the same least squares linear regression method employed above (research question one), and the $\alpha$ coefficients were estimated. These $\alpha$ 's were then separated into their respective sectors, and an Analysis of Variance (ANOVA) was performed to test the null hypothesis that all their population means were equal (Ho: $\mu 1=\mu 2=\mu 3=\mu 4=\mu 5=\mu 6=\mu 7=\mu 8$ $=\mu 9=\mu 10)$ versus the alternative hypothesis that at least one of the sectors mean $\alpha$ is different. The results of the analysis can be seen in Table $\mathrm{X}$ below.

TABLE X

TEST OF EQUALITY OF JENSEN ALPHAS FOR REIT SECTORS USING ANOVA

\begin{tabular}{|l|l|l|l|l|}
\hline Source of Variation & SS & Df & $M S$ & $F$ \\
\hline
\end{tabular}




\begin{tabular}{|l|r|r|r|r|}
\hline Between Groups & 0.0068 & 9 & 0.0008 & 3.8720 \\
\hline Within Groups & 0.0560 & 287 & 0.0002 & \\
\hline & & & & \\
\hline Total & 0.0628 & 296 & & \\
\hline
\end{tabular}

F-Value is significant at the 0.001 level.

The results from the one-way analysis of variance show that we can reject the null hypothesis at the 0.01 level, thus, concluding that at least one of the REIT sector's have a different mean Jensen $\alpha$. However, we still don't know which population mean or means are different than the rest. Thus, in order to determine if lodging REITs have a different mean population Jensen alpha a Tukey test comparison was conducted on the data. In this type of comparison each REIT sectors' mean is compared to the lodging sector's mean to determine if a statistically significant difference exists. Table XI below shows the results of this comparison.

TABLE XI

CALCULATION OF TEST STATISTICS IN JENSEN ALPHA USING TUKEY

METHOD

JANUARY 1999 - DECEMBER 2005

\begin{tabular}{|l|l|l|}
\hline & Mean Difference & Two tailed $p$-value \\
\hline
\end{tabular}




\begin{tabular}{|c|c|c|}
\hline$\mu 2-\mu 1$ & 0.0055 & 0.1881 \\
\hline$\mu 3-\mu 1$ & 0.0056 & 0.2789 \\
\hline$\mu 4-\mu 1$ & 0.0130 & 0.0189 \\
\hline$\mu 5-\mu 1$ & 0.0166 & 0.1538 \\
\hline$\mu 6-\mu 1$ & 0.0028 & 0.4945 \\
\hline$\mu 7-\mu 1$ & 0.0023 & 0.5645 \\
\hline$\mu 8-\mu 1$ & -0.0002 & 0.9616 \\
\hline$\mu 9-\mu 1$ & 0.0089 & 0.0351 \\
\hline$\mu 10-\mu 1$ & -0.0079 & 0.4658 \\
\hline \multicolumn{3}{|c|}{$\begin{array}{l}\mu 1=\text { mean Jensen alpha for Lodging REITs. } \\
\mu 2=\text { mean Jensen alpha for Diversified REITs. } \\
\mu 3=\text { mean Jensen alpha for Health Care REITs. } \\
\mu 4=\text { mean Jensen alpha for Industrial REITs. } \\
\mu 5=\text { mean Jensen alpha for Mixed REITs. } \\
\mu 6=\text { mean Jensen alpha for Office REITs. } \\
\mu 7=\text { mean Jensen alpha for Residential REITs. } \\
\mu 8=\text { mean Jensen alpha for Retail REITs. } \\
\mu 9=\text { mean Jensen alpha for Self Storage REITs. } \\
\mu 10=\text { mean Jensen alpha for Specialty REITs. }\end{array}$} \\
\hline
\end{tabular}

Since the value was calculated as the various REIT sectors minus the lodging REIT sector we can see that lodging REITs have a lower Jensen alpha on average than all other sectors except the Retail and Specialty sectors. The difference is significant at 0.05 levels for the Industrial and Self Storage REIT sectors. Thus, there is no evidence to suggest that lodging REITs over-performed the other REIT sectors. The reverse is actually the case when compared to the Industrial and Self Storage sectors. Effectively, the results indicated that lodging REITs performed better than some sectors and worse than others. 


\section{Research Question Three}

To answer research question three, the data were divided into two sample periods to see if there was a substantial difference in the Jensen alphas or betas between them. A similar analysis was conducted (Kim et al., 2002) using data from the period January 1993 to December 1999, so it was decided to use this time frame as the first period. The period from January 2000 to December 2005 therefore represented the second period. The following model was used to determine if there is indeed a difference between the two periods:

$$
\left(R_{i, t}-R_{f, t}\right)=\alpha_{1 i}+\beta_{1 i} *\left(R_{m, t}-R_{f, t}\right)+\alpha_{2 i} * D_{2}+\beta_{1 i} * D_{2} *\left(R_{m, t}-R_{f, t}\right)+a_{i, t}
$$

Where $R_{t, t}$ is the return on portfolio i at time $\mathrm{t} ; R_{f, t}$ is the return on the risk-free asset at time $\mathrm{t} ; \mathbb{R}_{m, t}$ is the market return at time $\mathrm{t} ; \boldsymbol{\alpha}_{1}$ is the Jensen Index measure of performance on portfolio i during the first period; $\beta_{1 l}$ is the systematic risk for portfolio i during the first period; $D_{2}$ is a dummy variable that takes the value one for the first period and zero for the second period; $\alpha_{z i}$ is the Jensen Index measure of performance on portfolio i during the second period; $\beta_{a l}$ is the systematic risk for portfolio i during the second period; and $\varepsilon_{i, t}$ is the random error with expected value equal to zero.

The use of dummy variables (for alpha and beta for the first period) allowed for the testing of differences across the two periods. The null hypothesis is that there is not a difference in the alphas or betas over the two periods (i.e. $\alpha_{\mathbf{n} \bar{i}}=0$ and $\beta_{\mathbf{n} l}=0$ ). Table XII below shows the results.

TABLE XII 


\section{CALCULATION OF DIFFERENCE IN PERIOD PARAMETERS FOR LODGING REIT SECTOR}

\begin{tabular}{|l|c|c|c|}
\hline \multicolumn{1}{|c|}{ Variable } & Coeffeficient & T-value & Significents \\
\hline$\alpha_{1 i}$ & .007 & 1.506 & .134 \\
\hline$\alpha_{1 i}$ & -.012 & -1.765 & .080 \\
\hline$\beta_{1 i}$ & .422 & 5.149 & .000 \\
\hline$\beta_{2 i}$ & .954 & 13.442 & .000 \\
\hline
\end{tabular}

Examining the data, we can see that both $\alpha_{z i}$ and $\beta_{3 i}$ can be rejected at the 0.10 and 0.01 levels respectively. Thus we conclude that both the level of over-performance and risk has changed between the two periods for the lodging REIT sector. Hence, we can see that the performance of lodging REITs during both periods is not consistent with each other. 


\section{CHAPTER V}

\section{CONCLUSION}

Investment in real estate investment trusts (REITs) have become REITs have become common in today's marketplace. As such, it behooves prudent investors and managers of such assets to constantly track and monitor the performance of real estate investment trusts. The purpose of this research was to examine the performance of lodging real estate investment trusts (lodging REITs) during the period January 1993 through December 2005. Specifically, the study examined lodging REITs relative to standard industry market portfolios or benchmarks (the S\&P 500, the CRSP value weighted and CRSP equally weighted index, and the NASDAQ composite) and other equity REITs. The study also ascertained if the performance of lodging REITs was consistent from one period to another.

The results of the study indicted that overall, the performance of lodging REITs was inferior to the market portfolios as well as other REIT sectors as a whole. This finding is consistent with a previous study conducted by Kim et al., (2002). There are several plausible explanations for these findings. First and foremost is the fact that the performance of individual REITs is intricately linked to the performance of the underlying asset (Brounen et al., 2000). For example, whenever the economy is stagnant, companies and individuals will curtail or reduce 
their travel budgets. Such was the case during the 1991 to 1992 economic recession when occupancy and average rates were depressed. We can therefore see that in periods of economic downturn, hotels room rates and occupancy will be negatively affected, which will inadvertently depress the overall value of lodging REITs. Conversely, when the economy is robust, travel increases and consequently demand for lodging, which allows such facilities to increase their average daily rates. Such was the case between 1995 and 1996 when lodging REITs benefited from a robust economy. However, the lodging segment of the REIT industry is often considered to be the most susceptible to changing economic conditions and non-recurring events. For example, these are events such as the one that occurred on September 11, 2001, which greatly reduced demand for lodging. Such events also have the net effect of not only reducing demand for lodging, but also the overall value of REITs. On the other hand, market composites such as the S\&P 500 comprise a diversity of companies from various industries, many of which are recession resistant. Hence, lodging REITs will generally underperform such market portfolios.

The notion that the underlying asset drives the value of the REIT also holds true for the other Equity REITs as well. The results indicated that the Industrial and Self Storage segments of the equity REIT consistently over performed the market. This is because unlike lodging REITs, these sectors usually require long-term leases and are therefore less susceptible to recessions.

The performance of lodging REITs against other equity REITs may also be inferior due to the fact that lodging REITs emerged as viable investment vehicles in 1993. On the other hand, other segments of the equity REIT market have traded in the marketplace for a longer 
period of time. As such, they have gone through more investment and business cycles than lodging REITs and consequently would have gained investors' confidence. Hence, a fairer comparison might entail adjustments for the broader market's return so as to provide a fairer comparison between REITs that were not being traded at the same time (as other equity REITs). For example, it may be argued that with only 10 lodging REITs trading in 1995, (one of the market's best years), but 16 trading in 2002 (one of the broader market's worst year), that the lodging segment might be unfairly punished. In summary, lodging REITs investigated in this study did not over perform the broader equity REIT market.

The issue of lodging REIT performance persistence was also a focus of this study. In this regard, the performance of lodging REITs was not found to be persistent, which means that their overall performance was not consistent over time. The issue of performance persistence is important for investors, especially those that make decisions based on the past performance of a fund. However, this lack of persistence in performance is not unusual (Bauman \& Miller, 1994;Phelps \& Detzel, 1997). This finding has important implications for investors since information from the past is often of little value in predicting the future performance. Instead, it behooves prudent investors to pay particular attention to the management of the REITs as well as the management of the underlying assets. They should also pay attention to the performance of the economic segment of the industry in which the REIT participates. In summary, although lodging REITs were found not to be persistent, past information on the performance of investments is often of little value if used by themselves. Thus, such information should be used in conjunction with information such as the ability of the investment to perform admirably under adverse market conditions. 
In addition, from a practical perspective, it is also advisable that investors especially institutional investors recruit and hire investment managers who have proven track records of delivering exceptional returns. In addition, such manager's performance should be evaluated in relation to relative benchmarks that reflect the overall returns on comparable investments. It is also advisable that investors carefully examine the timing of investment performance. For example, if an investment over performs relevant benchmarks or market portfolios during recessions or during periods when the overall market is down, then it should provide some level of assurance that it is an investment worth securing. Conversely, if an investment that performs superbly during periods of market upsurge, caution should be exercised before labeling this investment as an excellent choice.

Although the results of this study are constrained by the small sample size, it is hopeful that the empirical findings will help prudent investors in better understanding the return characteristics and performance of lodging REITs and can be useful to both individual and institutional investors who hold, or intend to hold asset portfolios that include lodging REITs. In addition, this research highlights the fact that the historical performance of the REITs should be used only as a guide towards developing investment strategies since the performance of investments varies over time.

\section{Study Limitations And Suggestions For Further Research}

Although this study investigated the performance of lodging REITs, the universe of lodging REITs was confined to US lodging REITs. Future studies could examine and compare the performance of US lodging REITs and other REIT markets such as those in Canada and the 
United Kingdom. In addition, the study employed only one method-the Jensen Index, to measure performance. Future studies could utilize multiple measures of performance.

In the final analysis, future research should also be directed to address questions such as: Are lodging REITs significantly different from common stocks in risk and return performance to warrant inclusion in a portfolio to enhance diversification benefits? Another interesting study in the area of lodging REITs would be to focus on the performance of lodging REITs within each segment of the lodging industry. Future research could also focus on the relationship between lodging REIT performance and key lodging industry indicators such as REVPAR. 


\section{REFERENCES}

Admati, A., Bhattacharya, S., Pfleiderer, P., \& Ross, S. (1986). On Timing and Selectivity. Journal of Finance, 41, 715-731.

Asbere, P. K., Kleiman, R. T., \& McGowan, C. B. (1991). The risk-return attributes of international real estate equities. Journal of Real Estate Research, 6(2), 143-151.

Bauman, W. S., \& Miller, R. E. (1994). Can Managed Portfolio Performance be Predicted? The Journal of Portfolio Management, 20(4), 31-40.

Beals, P., \& Arabia, J. V. (1998). Lodging REITs: Ready for an encore. Cornell Hotel and Restaurant Administration Quarterly, 39(6), 52-59.

Beals, P., \& Arabia, J. V. (2003). Lodging REITs. In L. E. Raleigh, \& R. J. Roginsky (Eds.), Hotel Investments: Issues \& Perspectives (3rd ed., pp. 167-181). Lansing, MI: American Hotel \& Lodging Educational Institute.

Beneveniste, L., Capozza, D., \& Seguin, P. (2001). The Value of Liquidity. Real Estate Economics, 29, 633-660.

Bergsman, S. (2001). REITs-Partner Up with Pension Funds in Joint Ventures. Journal of Property Management, 66(5), 74-77.

Block, R. L. (1998). Investing in REITs: Real Estate Investment Trusts. Princeton, NJ: Bloomberg Press.

Block, S. B., \& French, D. W. (2002). The Effect of Portfolio Weighting on Investment 
Performance Evaluation: The Case of Actively Managed Mutual Funds. Journal of Economics and Finance, 26(1), 16-30.

Brady, P. J., \& Conlin, M. E. (2004, January). The Performance of REIT-owned Properties and the Impact of REIT Market Power. Journal of Real Estate Finance and Economics, 28(1), 81-95.

Brounen, D. P., Eicholtz, M. A., \& Kanters, P. M. (2000). The Effects of Property development Activities on the Performance of REITs. Real Estate Finance, 16(4), 17-22.

Brown, D. T. (2000). Liquidity and Liquidation: Evidence from real estate investment trusts. Journal of Finance, 55(1), 469-485.

Brueggeman, W. B., \& Fisher, J. D. (2005). Real Estate Finance and Investments (12th ed.). Boston: McGraw-Hill Irwin.

Cannon, S. E., \& Vogt, S. C. (1995). REITs and their management: an analysis of organizational structure, performance and management compensation. Journal of Real Estate Research, $10(3), 297-317$.

Capozza, D., \& Seguin, P. (2001). Why Focus Matters. Real Estate Finance, 17, 7-16.

Capozza, D., \& Seguin, P. (2003). Inside Ownership, Risk Sharing and Tobin's q-Ratios: Evidence from REITs. Real Estate Economics, 31, 367-404.

Chan, K. C., Hendershott, P. H., \& Sanders, A. B. (1990). Risk and Return on the Real Estate: Evidence from Equity REITs. AREUEA Journal, 18(winter), 431-452.

Chan, S. H., Erickson, J., \& Wang, K. (2003). Real Estate Investment Trusts: Structure, Performance, and Investment Opportunities (1st ed.). New York: Oxford University Press. 
Chan, S. H., Leung, W. K., \& Wang, K. (1998). Institutional Investment in REITs: Evidence and Implications. Journal of Real Estate Research, 16(3), 357-374.

Chan, S. H., Leung, W., \& Wang, K. (2005). Changes in RTEIT Structure and Stock Performance: Evidence from the Monday Stock Anomaly. Real Estate Economics, 33(1), 89-120.

Chatrath, A., \& Liang, Y. (1998). REITs and Inflation: A Long-Run Perspective. Journal of Real Estate Research, 16(3), 311-325.

Chen, J., \& Peiser, R. (1999). The risk and return characteristics of REITs. Real Estate Finance, 16, 61-68.

Clayton, J., \& MacKinnon, G. (2003, July). The Relative Importance of Stock, Bond and Real Estate Factors in Explaining REIT Returns. Journal of Real Estate Finance \& Economics, 27(1), 39-60.

Corgel, J. B., McIntosh, W., \& Ott, S. H. (1995). Real Estate Investment trust: A Review of Financial Economic Literature. Journal of Real Estate Literature, 3(1), 13-43.

Crain, J. J., Cudd, M., \& Brown, C. L. (2000). The impact of the Revenue Reconciliation act of 1993 on the pricing structure of equity REITs. Journal of Real Estate Research, 19(3), 275-285.

Daniel, K., Grinblatt, M., Titman, S., \& Wermers, R. (1997). Measuring Mutual Fund Performance with characteristic-based benchmarks. Journal of Finance, 52, 1035-1057.

DeRoos, J. (1997). Real estate in the hospitality curriculum. The Hospitality Financial Management Review, 9(4), 7.

Edmunds, J. C. (1982). Why REIT stocks are undervalued. Real Estate Review, 12(Fall), 96-99. 
Fama, E., \& French, K. (1993). Common Risk factors in the Return on Stocks and Bonds. Journal of Financial Economics , 3, 3-56.

Friend, I., Blume, M., \& Crockett, J. (1970). Mutual Funds and other institutional investors: A new Perspective (1 ed.). New York: McGraw Hill.

Giliberto, S. M. (1990). Equity Real Estate Investment Trusts and Real Estate Returns. Journal of real Estate Research, 5(summer), 259-263.

Glascock, J. L., \& Hughes, W. T. (1995). NAREIT identified exchange listed REITs and their performance characteristics: 1972-1991. Journal of Real Estate literature, 3, 63-83.

Goebel, P. R., \& Kim, K. S. (1989, summer). Performance Evaluation of Finite-Life Real Estate Investment Trusts. Journal of Real Estate Research, 4, 57-69.

Gordon, S., \& McCarthy, W. (1998). Hotel REITS: The Great Disconnect. The Real Estate Finance Journal, (winter), 59-64.

Grissom, T. V., Kuhle, J. L., \& Walther, C. H. (1978). Diversification work in real estate too. Journal of Portfolio Management, 5(2), 66-71.

Gu, Z., \& Gao, L. (2000). A multivariate model for predicting business failure of hospitality firms. Tourism and Hospitality Research: The Surrey Quarterly Review, 2(1), 37-50.

Gu, Z., \& Kim, H. (1998). Casino firm's risk features and their beta determinants. Progress in Tourism and Hospitality Research, 4, 357-365.

Gu, Z., \& Kim, H. (2003, May). An Examination of the Determinants of Hotel REITs Unsystematic Risk. International Council on Hotel, Restaurant and Institutional Education, 27(2), 166-184.

Gyourko, J. (1994). The long Term Prospects of the REIT Market. Real Estate Review, spring, 
$42-46$.

Gyourko, J., \& Sinai, T. (1999). The REIT Vehicle: Its Value Today and in the Future. Journal of Real Estate Research, 18(2), 355-375.

Haddock, G. (1998, March). Today's REITs differ radically from their Predecessors of 20 Years Ago-A Premium Choice. Journal of Accountancy, 85-87.

Haight, G. T., \& Fort, D. A. (1987). REITs: New Opportunities in real estate investment trusts (1st ed.). Chicago: Probus.

Han, J., \& Liang, Y. (1995, March). The Historical performance of Real Estate Investment Trusts. The Journal of Real Estate Research, 10(3), 235-262.

Hartzell, D., Hekman, J. S., \& Miles, M. (1987). Real Estate Returns and Inflation. AREUEA Journal, 15, 617-637.

Haugen, R. A. (2001). Modern Investment Theory (5th ed.). Upper Saddle River, NJ: Prentice Hall.

Howe, J. S., \& Shilling, J. D. (1990, winter). REIT Advisor Performance. AREUEA Journal, 18, 479-500.

IPO Vital Signs (2005). REIT IPO Update. Retrieved June 5, 2006, from http://www.ipovitalsings.com.

Imperiale, R. (2002). Real Estate Investment Trusts (1st ed.). New York: John Wiley \& Sons, Inc.

Jegadeesh, N. (1990, July). Evidence of Predictable Behavior in Security Returns. The Journal of Finance, 45(3), 881-898.

Jensen, M. C. (1968). The Performance of mutual funds in the Period 1945-1964. Journal of 
Finance, 23, 389-416.

Jensen, M. C. (1969). Risk, the Pricing of capital Assets, and the Evaluation of Investment Portfolios. Journal of Business, 42, 167-247.

Kim, H., Gu, Z., \& Mattila, A. S. (2002, May). Hotel Real Estate Investment Trusts' Risk Features and Beta Determinants. Journal of Hospitality \& Tourism Research, 26(2), 138154.

Kim, H., Mattila, A. S., \& Gu, Z. (2002). Performance of Hotel real estate investment trusts: a comparative analysis of Jensen indexes. International Journal of Hospitality Management, 21, 85-97.

Knight, R. A., \& Knight, L. G. (1992). REITs emergence as attractive investment vehicles. Real Estate Review, 22, 42-48.

Knight, R. A., \& Knight, L. G. (1993). REITs: An Attractive investment vehicle. The CPA Journal, 63(4), 34-42.

Kuhle, J. L. (1987, winter). Portfolio Diversification and Returns Benefits-Common Stock versus Real Estate Investment Trusts (REITs). Journal of Real Estate Research, 2(winter), 1-19.

Kuhle, J. L., Walther, C. H., \& Wurtzebach, C. H. (1986, August). The Financial Performance of Real Estate investment Trusts. The Journal of Real Estate Investment Trusts, 1(1), 67-75.

Lee, M., \& Lee, M. (2003). Institutional involvement and the REIT January effect over time. Journal of Property Investment \& Finance, 21(6), 435-449.

Lehmann, B., \& Modest, D. (1987). Mutual fund Performance evaluation: a comparison of benchmarks and benchmark comparisons. Journal of Finance, 42, 233-265.

Li, Y., \& Wang, K. (1995). The Predictability of REIT Returns and Market Segmentation. 
Journal of Real Estate Research, 471-82(10), 4.

Liang, Y., McIntosh, W., \& Ziering, B. (1999, 1999). REIT Correlations with Capital Markets Indexes: Separating Signal from Noise. Real Estate Finance, 15(4), 61-67.

Liow, K. H. (1997). The historical performance of Singapore property stocks. Journal of Property Finance, 8(2), 111-125.

Malley, M. (1997). Hotel REITs: Powerful but confusing. Hotel and Motel Management, 212(10), 55-63.

Martin, J. D., \& Cook, D. O. (1991). A comparison of the recent performance of publicly traded real property and portfolios and common stock. AREUEA Journal, 19(summer), 184-212.

McMahan, J. (1994). The Long view: A perspective on the REIT market. Real Estate Issues, 19, $1-4$.

Miller, J., \& Miller, M. L. (1986). Reliability and Validity in Qualitative research (1st Ed.). Beverly Hills: Sage Publications.

Mooradian, R. M., \& Yang, S. X. (2001, Jan-Mar). Dividend Policy and Firm Performance: Hotel REITs vs. Non-REIT Hotel Companies. Journal of Real Estate Portfolio Management, 7(1), 79-87.

Mueller, G. R., \& Anikeeff, M. A. (2001). Real estate ownership and operating businesses: Does combining them make sense for REITs? Journal of Real Estate Portfolio Management, $7(1), 55-65$.

Mullaney, J. A. (1998). REITs: Building Profits with real Estate Investment Trusts (1st Ed.). New York: John Wiley \& Sons.

Nahid, G. (2003). Understanding reliability and validity in qualitative research. Qualitative 
Report, 8(4), 597-607.

National Association of Real Estate Investment Trust (2006, May/June). Two More REITs Join S\&P 500. Retrieved June 6, 2006, from http://www.nareit.com/portfoliomag.

National Association of Real Estate Investment Trusts (2006, March/April). By the Numbers: 2005 IPO Activity. Retrieved June 5, 2006, from http://www.nareit.org.

National Association of Real Estate Investment Trusts, Inc (2006). . Retrieved May 01, 2006, from http://www.nareit.com.

National Association of Real Estate Investment Trusts, Inc. (2006). Historical REIT Industry Market Capitalization: 1972-2005. Retrieved April 29, 2006, from http://www.nareit.com/library/industry/marketcap.cfm.

National Association of Real Estate Investments Trusts (1978). REIT Factbook 1978. Washington, D.C.: National Association of Real Estate Investment Trust.

New York Institute of Finance (1988). Real Estate Investment Trusts: the Low risk, High Risk Yield Asset-Growth Opportunity. New York: New York Institute of Finance.

Oppenheimer, P., \& Grissom, T. V. (1998). Frequency Space Correlation between REITs and Capital Market Indices. Journal of Real Estate Research, 16(3), 291-309.

Ori, J. (1995). A seven step portfolio diversification strategy. Real Estate Review, 12(4), 481491.

Pablo, G. (1996, August 12). Natural-Born Deal Maker. Financial.

Phelps, S., \& Detzel, L. (1997). The Non-Persistence of Mutual Fund Performance. Quarterly Journal of Business and Economics, 36, 55-59.

Roll, R. (1978). Ambiguity when performance is measured by the security market line.. Journal 
of Finance, 1051-1069.

Rosen, K. (2001). Real Estate investment Trusts (REIT): A safe haven in volatile financial markets. Lend Lease Rosen. Research report (April Ed.). Berkeley, CA: Lend Lease Rosen.

Sagalyn, L. B. (1990). Real Estate risk and the Business cycle: Evidence from Security Markets. Journal of Real Estate Research, 5(2), 203-219.

Sanders, A. B. (1998). The historical behavior of REIT returns. In R. T. Garrigan, \& J. F. Parsons (Eds.), Real Estate Investment Trusts (1st ed., pp. 227-305). New York: McGraw-Hill.

Sanger, G. C., Sirmans, C. F., \& Turnbull, G. (1990). The effects of tax reform on real estate: Some Empirical results. Land Economics, 66, 409-424.

Sarheim, G. (2006, April). REIT or Wrong. Retrieved May 27th, 2006, from http://www.hvsinternational.com.

Sharpe, W. F. (1966). Mutual Fund Performance. Journal of Business, 39(1), 119-138.

Smith, K. V. (1980). Historical Returns of Real Estate Equity Portfolios (1st Ed.). Homewood, Ill: Dow Jones-Irwin.

Smith, K. V., \& Schulman, D. (1976). The performance of equity real estate investment trusts. Financial Analysts Journal, 32, 61-66.

Titman, S., \& Warga, A. (1986). Risk and the performance of the Real Estate Trusts: A Multiple Index Approach. AREUEA Journal, 14(3), 414-431.

Treynor, J. (1965, January/February). How to Rate Management of mutual funds. Harvard Business Review, 8, 272-289. 
Valachi, D. J. (1977). REITs: A historical perspective. Appraisal Journal, 45, 440-445.

Venmore-Rowland, P. (1989). Direct property and property shares. Journal of valuation, 8, 272289.

Wang, K., Erickson, J., Gau, G., \& Chan, S. H. (1995). Market microstructure and real estate returns. Real Estate Economics, 23, 85-100.

Wang, K., Erickson, J., Gau, G., \& Chan, S. H. (1997). Market microstructure and real estate returns. Real Estate Economics, 23, 85-100.

Yobaccio, E., Rubens, J., \& Ketcham, D. C. (1995). The inflation-hedging properties of risk assets: The case of REITs. The Journal of Real Estate Research, 10(3), 279-296.

Zell, S. (1998, 1998). The REIT industry in the next Four Years: A Glance around the Corner. Real Estate Review, 28(4), 36-39. 
APPENDICES 


\section{APPENDIX A}

MONTHLY REIT RETURNS (1993-2005)

\begin{tabular}{|c|c|c|c|c|c|c|c|c|c|c|c|}
\hline Date & Diversified & Health Care & Industrial & Lodging & Mixed & Office & Residential & Retail & $\begin{array}{c}\text { Self } \\
\text { Storage } \\
\end{array}$ & Specialty & Total \\
\hline Jan-93 & $9.75 \%$ & $3.63 \%$ & $4.47 \%$ & $28.05 \%$ & $11.36 \%$ & $5.16 \%$ & $8.17 \%$ & $4.40 \%$ & $7.18 \%$ & $1.79 \%$ & $5.76 \%$ \\
\hline Feb-93 & $9.63 \%$ & $-3.67 \%$ & $10.34 \%$ & $-9.90 \%$ & $10.37 \%$ & $2.13 \%$ & $7.09 \%$ & $4.38 \%$ & $5.30 \%$ & $0.00 \%$ & $3.97 \%$ \\
\hline Mar-93 & $1.71 \%$ & $10.11 \%$ & $1.83 \%$ & $49.00 \%$ & $3.80 \%$ & $12.14 \%$ & $9.39 \%$ & $7.40 \%$ & $6.80 \%$ & $1.75 \%$ & $7.87 \%$ \\
\hline Apr-93 & $-6.93 \%$ & $-1.53 \%$ & $9.81 \%$ & $-2.34 \%$ & $-6.88 \%$ & $-4.81 \%$ & $-5.00 \%$ & $-5.75 \%$ & $0.54 \%$ & $-3.45 \%$ & $-4.30 \%$ \\
\hline May-93 & $-2.67 \%$ & $1.31 \%$ & $-3.21 \%$ & $23.51 \%$ & $18.60 \%$ & $-1.82 \%$ & $-3.84 \%$ & $-1.65 \%$ & $1.12 \%$ & $0.00 \%$ & $-1.29 \%$ \\
\hline Jun-93 & $2.55 \%$ & $1.42 \%$ & $1.45 \%$ & $-2.83 \%$ & $-0.94 \%$ & $-1.81 \%$ & $3.51 \%$ & $3.41 \%$ & $2.27 \%$ & $-1.79 \%$ & $2.56 \%$ \\
\hline Jul-93 & $2.12 \%$ & $-0.60 \%$ & $2.50 \%$ & $2.14 \%$ & $-1.46 \%$ & $3.39 \%$ & $4.06 \%$ & $-0.61 \%$ & $5.07 \%$ & $3.64 \%$ & $1.11 \%$ \\
\hline Aug-93 & $3.70 \%$ & $-0.90 \%$ & $5.00 \%$ & $3.77 \%$ & $-2.35 \%$ & $5.84 \%$ & $2.05 \%$ & $2.04 \%$ & $7.27 \%$ & $0.88 \%$ & $2.29 \%$ \\
\hline Sep-93 & $4.76 \%$ & $6.36 \%$ & $9.50 \%$ & $14.70 \%$ & $-5.76 \%$ & $0.68 \%$ & $8.81 \%$ & $1.81 \%$ & $6.20 \%$ & $1.79 \%$ & $4.81 \%$ \\
\hline Oct-93 & $-3.14 \%$ & $-0.05 \%$ & $7.66 \%$ & $5.90 \%$ & $0.99 \%$ & $4.98 \%$ & $-0.21 \%$ & $-4.24 \%$ & $-1.41 \%$ & $-2.58 \%$ & $-1.66 \%$ \\
\hline Nov-93 & $-2.84 \%$ & $-4.10 \%$ & $-9.76 \%$ & $-0.27 \%$ & $10.36 \%$ & $-5.17 \%$ & $-7.44 \%$ & $-5.41 \%$ & $-1.75 \%$ & $-9.73 \%$ & $-5.37 \%$ \\
\hline Dec-93 & $-2.35 \%$ & $-0.26 \%$ & $-1.37 \%$ & $2.57 \%$ & $-17.56 \%$ & $-1.20 \%$ & $3.00 \%$ & $-0.85 \%$ & $-2.72 \%$ & $20.57 \%$ & $0.23 \%$ \\
\hline Jan-94 & $2.93 \%$ & $4.89 \%$ & $2.08 \%$ & $-0.93 \%$ & $13.50 \%$ & $3.09 \%$ & $0.85 \%$ & $3.14 \%$ & $5.89 \%$ & $-8.63 \%$ & $2.68 \%$ \\
\hline Feb-94 & $0.71 \%$ & $3.51 \%$ & $4.87 \%$ & $8.91 \%$ & $1.96 \%$ & $4.09 \%$ & $6.37 \%$ & $4.38 \%$ & $-2.76 \%$ & $0.51 \%$ & $4.19 \%$ \\
\hline Mar-94 & $-3.02 \%$ & $-2.66 \%$ & $-0.09 \%$ & $-1.14 \%$ & $-7.29 \%$ & $-4.52 \%$ & $-5.40 \%$ & $-3.83 \%$ & $-3.96 \%$ & $-3.67 \%$ & $-3.91 \%$ \\
\hline Apr-94 & $-1.25 \%$ & $1.37 \%$ & $5.00 \%$ & $-3.24 \%$ & $-1.96 \%$ & $3.03 \%$ & $2.93 \%$ & $-0.24 \%$ & $2.50 \%$ & $0.62 \%$ & $1.22 \%$ \\
\hline May-94 & $2.38 \%$ & $0.45 \%$ & $3.19 \%$ & $5.33 \%$ & $1.02 \%$ & $1.64 \%$ & $2.20 \%$ & $1.55 \%$ & $4.20 \%$ & $6.03 \%$ & $1.93 \%$ \\
\hline Jun-94 & $-1.55 \%$ & $-0.81 \%$ & $0.98 \%$ & $3.93 \%$ & $-0.47 \%$ & $-2.05 \%$ & $-5.32 \%$ & $-1.11 \%$ & $-1.51 \%$ & $1.14 \%$ & $-1.97 \%$ \\
\hline Jul-94 & $0.44 \%$ & $-0.94 \%$ & $1.18 \%$ & $-3.09 \%$ & $-1.91 \%$ & $2.20 \%$ & $-0.62 \%$ & $-1.72 \%$ & $1.27 \%$ & $2.25 \%$ & $-0.67 \%$ \\
\hline Aug-94 & $1.41 \%$ & $2.55 \%$ & $-2.45 \%$ & $-2.34 \%$ & $1.07 \%$ & $1.77 \%$ & $-0.64 \%$ & $-0.16 \%$ & $0.04 \%$ & $-1.10 \%$ & $0.03 \%$ \\
\hline Sep-94 & $-2.06 \%$ & $2.44 \%$ & $-4.75 \%$ & $-3.17 \%$ & $0.65 \%$ & $-4.87 \%$ & $-1.51 \%$ & $-2.63 \%$ & $1.16 \%$ & $-5.44 \%$ & $-1.88 \%$ \\
\hline Oct-94 & $-4.34 \%$ & $-4.30 \%$ & $-1.75 \%$ & $-3.70 \%$ & $-3.70 \%$ & $-2.08 \%$ & $-4.66 \%$ & $-4.06 \%$ & $-4.25 \%$ & $-1.42 \%$ & $-3.97 \%$ \\
\hline Nov-94 & $-2.06 \%$ & $-6.32 \%$ & $-1.70 \%$ & $-8.57 \%$ & $-5.27 \%$ & $-5.29 \%$ & $-3.92 \%$ & $-3.47 \%$ & $-2.51 \%$ & $-8.78 \%$ & $-3.82 \%$ \\
\hline Dec-94 & $5.57 \%$ & $5.22 \%$ & $9.92 \%$ & $4.25 \%$ & $9.18 \%$ & $2.82 \%$ & $10.58 \%$ & $5.84 \%$ & $3.96 \%$ & $21.04 \%$ & $7.19 \%$ \\
\hline Jan-95 & $-0.89 \%$ & $1.86 \%$ & $-4.19 \%$ & $-3.90 \%$ & $0.78 \%$ & $-1.26 \%$ & $-5.25 \%$ & $-2.58 \%$ & $1.74 \%$ & $-6.47 \%$ & $-2.58 \%$ \\
\hline Feb-95 & $2.05 \%$ & $3.03 \%$ & $2.56 \%$ & $5.36 \%$ & $2.87 \%$ & $3.63 \%$ & $0.18 \%$ & $2.64 \%$ & $3.48 \%$ & $3.14 \%$ & $2.15 \%$ \\
\hline Mar-95 & $0.54 \%$ & $1.63 \%$ & $-1.52 \%$ & $3.17 \%$ & $-3.98 \%$ & $2.06 \%$ & $-0.88 \%$ & $-1.52 \%$ & $6.56 \%$ & $-6.96 \%$ & $-0.28 \%$ \\
\hline Apr-95 & $-1.34 \%$ & $-2.95 \%$ & $-2.47 \%$ & $2.54 \%$ & $-3.31 \%$ & $0.71 \%$ & $0.08 \%$ & $-1.35 \%$ & $-1.62 \%$ & $-1.45 \%$ & $-1.04 \%$ \\
\hline May-95 & $2.54 \%$ & $3.67 \%$ & $3.17 \%$ & $0.98 \%$ & $3.85 \%$ & $5.06 \%$ & $3.84 \%$ & $4.12 \%$ & $-0.22 \%$ & $10.51 \%$ & $3.65 \%$ \\
\hline Jun-95 & $2.63 \%$ & $1.03 \%$ & $3.63 \%$ & $1.76 \%$ & $1.08 \%$ & $1.76 \%$ & $0.41 \%$ & $1.55 \%$ & $1.18 \%$ & $-2.76 \%$ & $1.41 \%$ \\
\hline Jul-95 & $0.62 \%$ & $1.78 \%$ & $-0.71 \%$ & $2.94 \%$ & $1.40 \%$ & $1.61 \%$ & $1.43 \%$ & $0.86 \%$ & $2.88 \%$ & $-1.71 \%$ & $1.18 \%$ \\
\hline Aug-95 & $0.88 \%$ & $-2.00 \%$ & $1.08 \%$ & $2.34 \%$ & $1.02 \%$ & $0.78 \%$ & $0.77 \%$ & $-0.29 \%$ & $3.17 \%$ & $5.92 \%$ & $0.40 \%$ \\
\hline
\end{tabular}




\begin{tabular}{|c|c|c|c|c|c|c|c|c|c|c|c|}
\hline Sep-95 & $0.90 \%$ & $4.75 \%$ & $2.67 \%$ & $5.64 \%$ & $5.04 \%$ & $3.87 \%$ & $1.32 \%$ & $0.31 \%$ & $2.14 \%$ & $-0.04 \%$ & $1.84 \%$ \\
\hline Oct-95 & $-1.23 \%$ & $-5.06 \%$ & $-0.19 \%$ & $-2.17 \%$ & $-3.28 \%$ & $2.07 \%$ & $-3.42 \%$ & $-5.19 \%$ & $-0.94 \%$ & $-0.93 \%$ & $-3.15 \%$ \\
\hline Nov-95 & $2.31 \%$ & $3.45 \%$ & $-0.89 \%$ & $-0.10 \%$ & $-3.32 \%$ & $0.47 \%$ & $2.55 \%$ & $-0.82 \%$ & $0.73 \%$ & $2.29 \%$ & $0.93 \%$ \\
\hline Dec-95 & $4.54 \%$ & $5.74 \%$ & $6.79 \%$ & $2.50 \%$ & $5.63 \%$ & $5.74 \%$ & $5.76 \%$ & $4.79 \%$ & $5.44 \%$ & $3.24 \%$ & $5.26 \%$ \\
\hline Jan-96 & $0.20 \%$ & $9.67 \%$ & $3.57 \%$ & $7.76 \%$ & $6.20 \%$ & $3.74 \%$ & $1.65 \%$ & $-1.26 \%$ & $2.22 \%$ & $2.09 \%$ & $2.34 \%$ \\
\hline Feb-96 & $-0.34 \%$ & $-1.37 \%$ & $0.00 \%$ & $2.59 \%$ & $-1.18 \%$ & $1.07 \%$ & $2.12 \%$ & $-0.02 \%$ & $0.97 \%$ & $8.29 \%$ & $0.62 \%$ \\
\hline Mar-96 & $-0.30 \%$ & $-4.11 \%$ & $-2.45 \%$ & $-1.55 \%$ & $-5.10 \%$ & $-0.10 \%$ & $-1.30 \%$ & $0.59 \%$ & $0.71 \%$ & $-0.16 \%$ & $-0.91 \%$ \\
\hline Apr-96 & $0.51 \%$ & $-2.23 \%$ & $-0.36 \%$ & $-2.58 \%$ & $0.37 \%$ & $2.32 \%$ & $-0.60 \%$ & $-0.13 \%$ & $-0.98 \%$ & $-2.73 \%$ & $-0.43 \%$ \\
\hline May-96 & $1.59 \%$ & $-0.16 \%$ & $1.29 \%$ & $4.86 \%$ & $-1.19 \%$ & $1.69 \%$ & $0.75 \%$ & $3.00 \%$ & $0.66 \%$ & $-0.59 \%$ & $1.69 \%$ \\
\hline Jun-96 & $2.97 \%$ & $-1.01 \%$ & $0.87 \%$ & $-0.99 \%$ & $-2.30 \%$ & $0.38 \%$ & $0.87 \%$ & $2.14 \%$ & $-0.98 \%$ & $-0.98 \%$ & $0.88 \%$ \\
\hline Jul-96 & $1.41 \%$ & $-3.18 \%$ & $1.30 \%$ & $-2.95 \%$ & $0.21 \%$ & $0.54 \%$ & $-0.40 \%$ & $-0.35 \%$ & $1.05 \%$ & $6.36 \%$ & $-0.33 \%$ \\
\hline Aug-96 & $4.02 \%$ & $6.54 \%$ & $3.95 \%$ & $5.72 \%$ & $7.30 \%$ & $4.80 \%$ & $2.22 \%$ & $3.27 \%$ & $2.71 \%$ & $4.79 \%$ & $3.79 \%$ \\
\hline Sep-96 & $0.78 \%$ & $0.99 \%$ & $1.82 \%$ & $5.42 \%$ & $1.62 \%$ & $2.15 \%$ & $1.36 \%$ & $0.86 \%$ & $3.28 \%$ & $2.64 \%$ & $1.68 \%$ \\
\hline Oct-96 & $2.83 \%$ & $-0.71 \%$ & $1.23 \%$ & $2.74 \%$ & $-0.26 \%$ & $0.37 \%$ & $3.52 \%$ & $1.37 \%$ & $2.36 \%$ & $3.99 \%$ & $1.84 \%$ \\
\hline Nov-96 & $5.12 \%$ & $3.90 \%$ & $4.92 \%$ & $5.41 \%$ & $6.88 \%$ & $4.84 \%$ & $2.63 \%$ & $3.85 \%$ & $7.63 \%$ & $-2.48 \%$ & $4.21 \%$ \\
\hline Dec-96 & $15.79 \%$ & $2.61 \%$ & $10.43 \%$ & $11.38 \%$ & $9.96 \%$ & $11.97 \%$ & $8.26 \%$ & $9.42 \%$ & $14.01 \%$ & $11.56 \%$ & $9.93 \%$ \\
\hline Jan-97 & $2.09 \%$ & $-1.32 \%$ & $1.18 \%$ & $5.41 \%$ & $0.66 \%$ & $0.98 \%$ & $1.27 \%$ & $-1.00 \%$ & $-3.65 \%$ & $-3.41 \%$ & $0.46 \%$ \\
\hline Feb-97 & $-0.18 \%$ & $4.11 \%$ & $1.07 \%$ & $-2.28 \%$ & $-7.17 \%$ & $1.21 \%$ & $-0.51 \%$ & $-0.63 \%$ & $-4.41 \%$ & $7.32 \%$ & $-0.18 \%$ \\
\hline Mar-97 & $4.73 \%$ & $1.66 \%$ & $-1.20 \%$ & $1.70 \%$ & $2.62 \%$ & $-1.26 \%$ & $-0.89 \%$ & $-1.33 \%$ & $3.62 \%$ & $-4.50 \%$ & $0.08 \%$ \\
\hline Apr-97 & $-2.81 \%$ & $2.17 \%$ & $-4.73 \%$ & $-2.41 \%$ & $-1.54 \%$ & $-5.36 \%$ & $-3.02 \%$ & $-2.03 \%$ & $-4.65 \%$ & $0.92 \%$ & $-2.78 \%$ \\
\hline May-97 & $3.91 \%$ & $1.52 \%$ & $1.52 \%$ & $0.65 \%$ & $0.06 \%$ & $1.24 \%$ & $3.68 \%$ & $2.65 \%$ & $1.18 \%$ & $5.47 \%$ & $2.36 \%$ \\
\hline Jun-97 & $9.15 \%$ & $3.18 \%$ & $4.10 \%$ & $7.75 \%$ & $3.77 \%$ & $4.33 \%$ & $2.96 \%$ & $4.30 \%$ & $5.66 \%$ & $5.89 \%$ & $4.66 \%$ \\
\hline Jul-97 & $-1.70 \%$ & $0.91 \%$ & $5.02 \%$ & $2.64 \%$ & $5.88 \%$ & $4.98 \%$ & $1.86 \%$ & $2.17 \%$ & $2.66 \%$ & $-6.27 \%$ & $2.41 \%$ \\
\hline Aug-97 & $0.44 \%$ & $-0.83 \%$ & $-2.54 \%$ & $0.31 \%$ & $-1.64 \%$ & $0.96 \%$ & $-1.23 \%$ & $-1.20 \%$ & $-3.56 \%$ & $4.09 \%$ & $-0.67 \%$ \\
\hline Sep-97 & $18.66 \%$ & $3.85 \%$ & $8.86 \%$ & $17.17 \%$ & $5.28 \%$ & $12.01 \%$ & $7.45 \%$ & $3.89 \%$ & $4.14 \%$ & $8.99 \%$ & $9.01 \%$ \\
\hline Oct-97 & $-2.63 \%$ & $-11.21 \%$ & $-0.38 \%$ & $0.21 \%$ & $3.94 \%$ & $-4.80 \%$ & $-4.27 \%$ & $-2.67 \%$ & $-6.10 \%$ & $-5.76 \%$ & $-3.65 \%$ \\
\hline Nov-97 & $2.07 \%$ & $-0.23 \%$ & $2.48 \%$ & $-4.96 \%$ & $-0.16 \%$ & $3.07 \%$ & $2.68 \%$ & $1.57 \%$ & $0.55 \%$ & $1.75 \%$ & $1.49 \%$ \\
\hline Dec-97 & $3.07 \%$ & $3.54 \%$ & $3.83 \%$ & $-0.76 \%$ & $1.78 \%$ & $2.23 \%$ & $0.48 \%$ & $2.00 \%$ & $5.34 \%$ & $14.74 \%$ & $2.11 \%$ \\
\hline Jan-98 & $-5.28 \%$ & $1.23 \%$ & $-0.61 \%$ & $-4.79 \%$ & $-4.45 \%$ & $-1.63 \%$ & $-1.12 \%$ & $0.80 \%$ & $5.75 \%$ & $-6.46 \%$ & $-1.12 \%$ \\
\hline Feb-98 & $-3.65 \%$ & $2.52 \%$ & $-2.60 \%$ & $-0.97 \%$ & $-1.55 \%$ & $-3.18 \%$ & $-2.54 \%$ & $-0.50 \%$ & $-3.82 \%$ & $5.15 \%$ & $-1.79 \%$ \\
\hline Mar-98 & $4.19 \%$ & $0.03 \%$ & $2.90 \%$ & $-1.31 \%$ & $0.98 \%$ & $2.41 \%$ & $2.52 \%$ & $1.60 \%$ & $-0.51 \%$ & $1.14 \%$ & $1.64 \%$ \\
\hline Apr-98 & $-5.51 \%$ & $-4.88 \%$ & $-4.63 \%$ & $-5.20 \%$ & $-4.45 \%$ & $-4.44 \%$ & $-2.40 \%$ & $-2.20 \%$ & $-0.95 \%$ & $-8.58 \%$ & $-3.73 \%$ \\
\hline May-98 & $-0.51 \%$ & $0.45 \%$ & $-0.55 \%$ & $-5.49 \%$ & $4.53 \%$ & $-1.97 \%$ & $0.74 \%$ & $-0.33 \%$ & $-1.55 \%$ & $-6.38 \%$ & $-1.24 \%$ \\
\hline Jun-98 & $0.07 \%$ & $-2.81 \%$ & $0.93 \%$ & $-0.23 \%$ & $-3.76 \%$ & $-0.93 \%$ & $-1.76 \%$ & $0.42 \%$ & $-5.21 \%$ & $-1.28 \%$ & $-0.74 \%$ \\
\hline Jul-98 & $-9.16 \%$ & $-5.57 \%$ & $-5.65 \%$ & $-15.22 \%$ & $-2.05 \%$ & $-7.82 \%$ & $-4.22 \%$ & $-4.68 \%$ & $-5.18 \%$ & $-11.71 \%$ & $-7.17 \%$ \\
\hline Aug-98 & $-13.28 \%$ & $-9.75 \%$ & $-8.40 \%$ & $-18.28 \%$ & $-9.44 \%$ & $-9.26 \%$ & $-7.42 \%$ & $-6.55 \%$ & $-10.42 \%$ & $-12.56 \%$ & $-9.79 \%$ \\
\hline Sep-98 & $6.50 \%$ & $9.96 \%$ & $10.71 \%$ & $-0.79 \%$ & $4.97 \%$ & $5.45 \%$ & $6.05 \%$ & $6.06 \%$ & $13.08 \%$ & $8.03 \%$ & $6.07 \%$ \\
\hline Oct-98 & $1.61 \%$ & $-3.72 \%$ & $-3.13 \%$ & $-7.01 \%$ & $-4.05 \%$ & $-2.53 \%$ & $-2.51 \%$ & $-0.42 \%$ & $-1.80 \%$ & $11.33 \%$ & $-2.18 \%$ \\
\hline Nov-98 & $4.63 \%$ & $-1.21 \%$ & $-0.85 \%$ & $1.65 \%$ & $6.86 \%$ & $3.02 \%$ & $0.05 \%$ & $0.18 \%$ & $0.08 \%$ & $1.63 \%$ & $1.16 \%$ \\
\hline Dec-98 & $-5.22 \%$ & $-0.67 \%$ & $-0.17 \%$ & $-11.85 \%$ & $0.16 \%$ & $-1.82 \%$ & $0.14 \%$ & $-1.53 \%$ & $1.32 \%$ & $-2.69 \%$ & $-2.23 \%$ \\
\hline Jan-99 & $-1.03 \%$ & $-2.08 \%$ & $-0.92 \%$ & $1.78 \%$ & $-4.51 \%$ & $-0.45 \%$ & $-1.98 \%$ & $-5.45 \%$ & $-4.82 \%$ & $-2.30 \%$ & $-2.01 \%$ \\
\hline
\end{tabular}




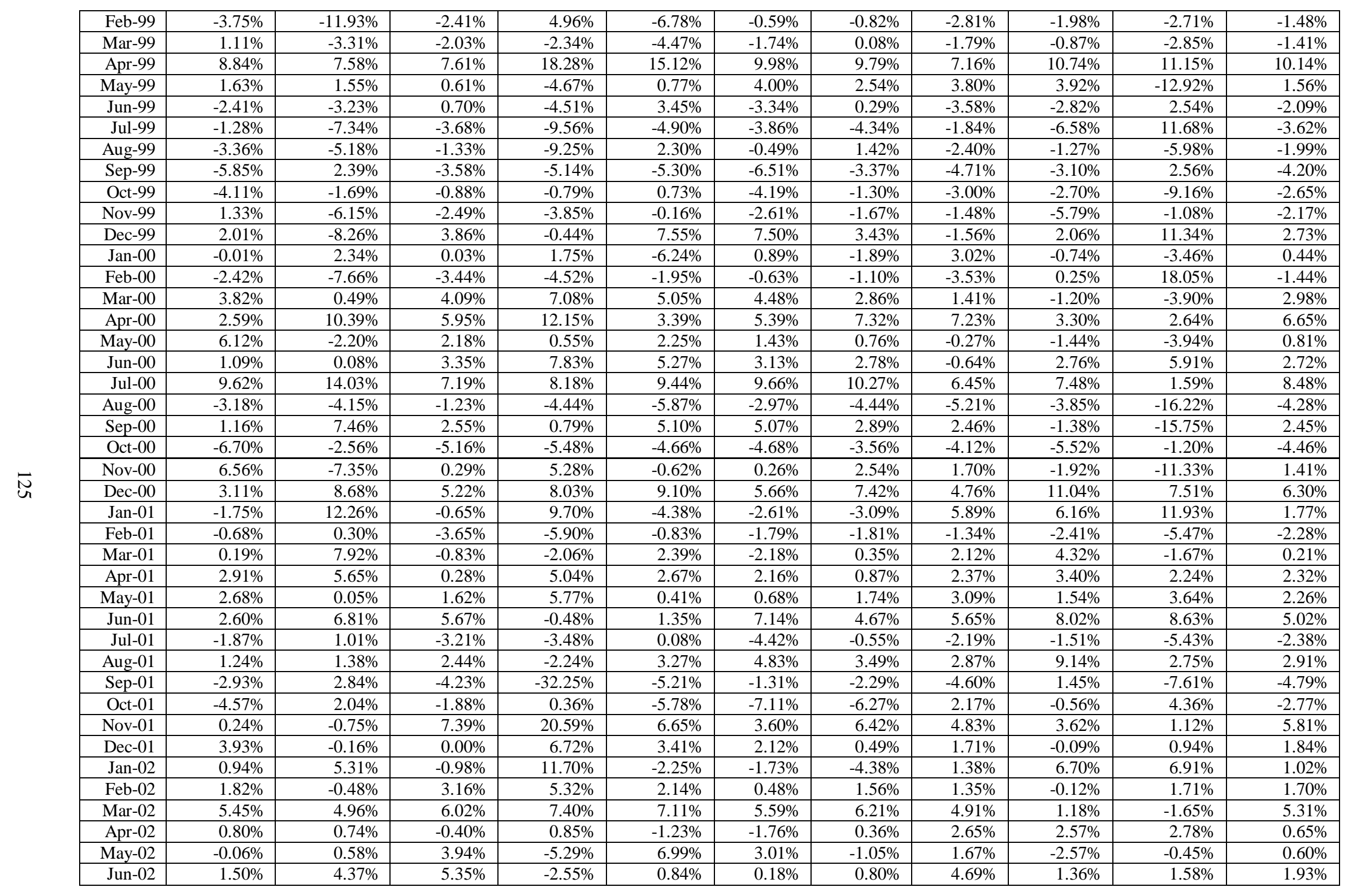




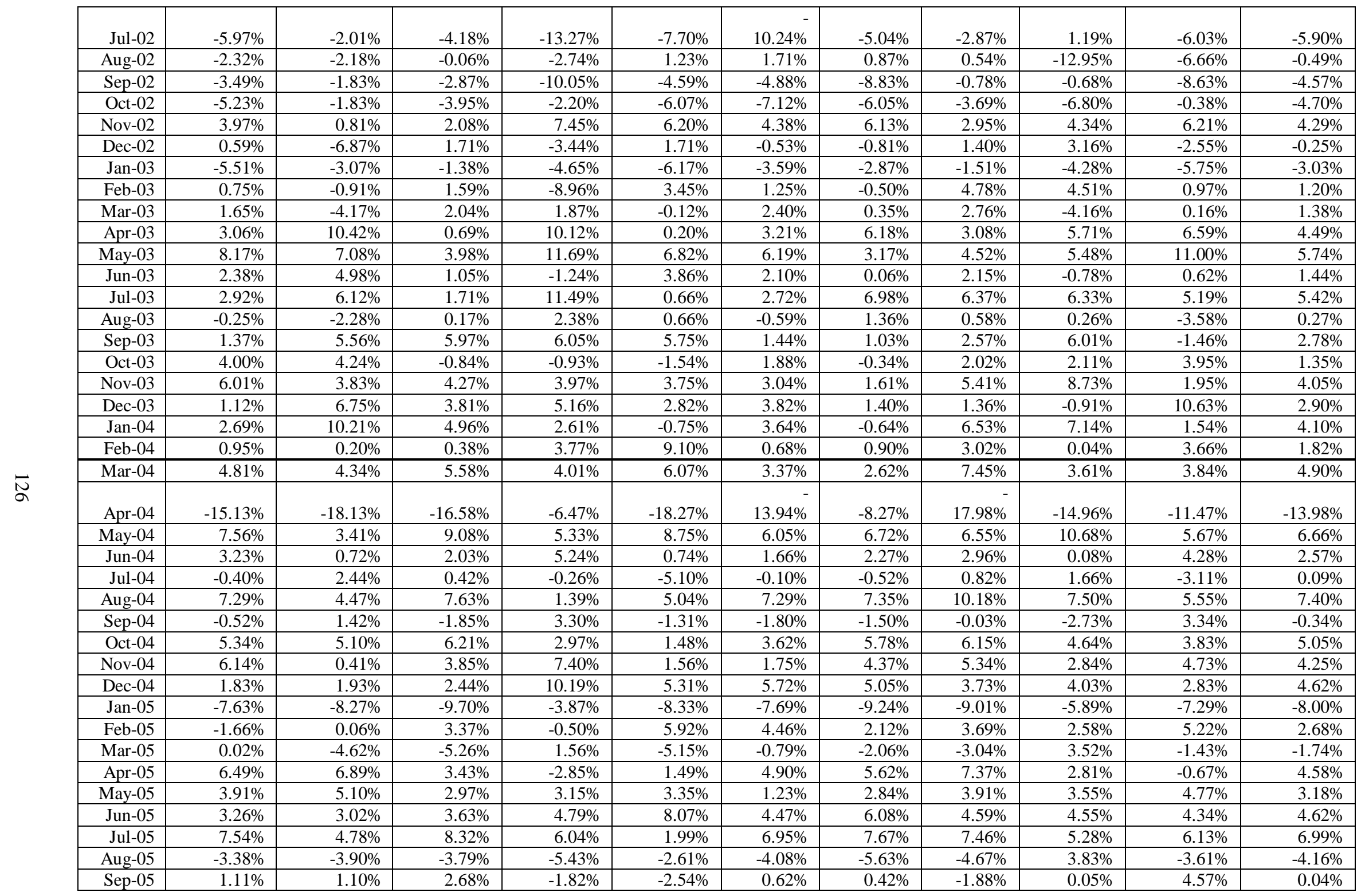




\begin{tabular}{|c|c|c|c|c|c|c|c|c|c|c|c|}
\hline Oct-05 & $-4.83 \%$ & $-5.00 \%$ & $-1.11 \%$ & $-0.72 \%$ & $-0.81 \%$ & $-3.38 \%$ & $1.20 \%$ & $-4.01 \%$ & $-0.79 \%$ & $-0.96 \%$ & $-2.25 \%$ \\
\hline Nov-05 & $3.47 \%$ & $0.56 \%$ & $3.49 \%$ & $6.76 \%$ & $3.79 \%$ & $3.86 \%$ & $3.17 \%$ & $4.86 \%$ & $5.59 \%$ & $2.12 \%$ & $4.08 \%$ \\
\hline Dec-05 & $-2.06 \%$ & $-2.45 \%$ & $2.12 \%$ & $3.84 \%$ & $0.72 \%$ & $-1.76 \%$ & $-0.95 \%$ & $-0.02 \%$ & $-3.41 \%$ & $-4.08 \%$ & $-0.43 \%$ \\
\hline
\end{tabular}


VITA

Leonard Anthony Jackson

Candidate for the Degree of

Doctor of Philosophy

\section{Dissertation: LODGING REIT PERFORMANCE AND COMPARISON WITH OTHER EQUITY REIT RETURNS}

Major Field: Human Environmental Sciences

Biographical:

Education: Received a Masters in Business Administration degree from the University of Guelph, Guelph, Canada in 2000; received a Bachelor of Arts degree from Ryerson University, Toronto, Canada, in 1998; received two Associate of Arts degrees in Hotel Management and Food and Beverage Management from George Brown College, Toronto, Canada in 1994; Completed the Requirements for the Doctor of Philosophy degree at Oklahoma State University in May, 2007.

Experience: Employed by Bethune-Cookman University as Instructor and Department Head , 2003 to 2007; employed by Johnson \& Wales University as an Assistant Professor 2002 to 2003; employed by the Park Hyatt Toronto as an Assistant Financial Controller 2000 to 2002, Toronto, Canada; Employed by Fairmont Hotels and Resorts as an Accountant 1998 to 1999 , Toronto, Canada.

Professional Memberships: Council on Hotel, Restaurant and Institutional Education (CHRIE), Hospitality Financial and Technology Professionals (HFTP), Association of Information Technology Professionals (AITP), Institute of Management Accountants (IMA), North American Case Research Association (NACRA). 
Title of Study:

LODGING REIT PERFORMANCE AND COMPARISON WITH OTHER EQUITY REIT RETURNS

Pages in Study: 127

Candidate for the Degree of Doctor of Philosophy

Major Field: Human Environmental Sciences

Scope and Method of Study: This study investigated the overall performance of lodging REITs during the period January 1993 to December 2005, relative to relevant industry benchmarks and other equity REITs. The Jensen Index was used to measure the performance of the various REIT sectors relative to the market benchmarks. The Tukey multiple comparison and a one way analysis of variance (ANOVA) were conducted to examine the performance of the various REIT sectors. Least Square Regression analysis was also employed.

Findings and Conclusions: The results of the study indicated that overall, the performance of lodging REITs was inferior to the market portfolios as a whole. Conversely, the industrial and self storage segments of the equity REIT market over performed the market. The performance of lodging REITs was also found not to be persistent. These findings suggest that the lodging REIT sector might not be as recession resistant as the industrial or self storage sectors. In addition, the fact that these sectors performed better than the lodging sector could be an indication that investors might not be as confident in lodging REITs as compared to those sectors. This could be due to the fact that lodging REITs emerged as viable investment vehicles in 1993, while the sectors that over performed the market have traded in the marketplace for longer periods. The findings also suggest that investors should pay attention to the management of REITs as well as the management of the underlying assets. In this regard, it behooves investors, particularly institutional investors to recruit and hire investment managers who have proven track records of delivering exceptional returns.

Adviser's Approval: Dr. Radesh Palakurthi 